\title{
ipen
}

AUTARQUIA ASSOCIADA À UNIVERSIDADE DE SÃO PAULO

\section{MECANISMOS DA TERAPIA FOTODINÂMICA EM PRESENÇA DE PERÓXIDO de HidRogênIO}

\author{
Aguinaldo Silva Garcez Segundo \\ Orientadora: Martha Simões Ribeiro
}

Tese apresentada como parte dos requisitos para a obtenção do Grau de Doutor em Ciências na Área de Tecnologia Nuclear - Materiais.

SÃO PAULO 
Aos meus pais Aguinaldo e Edna pelo esforço, dedicação e amizade que sempre demonstraram em cada passo da minha vida, permitindo-me, a partir de muito amor, carinho e incentivo, alcançar mais este objetivo. 
Aos meus sogros Hideo e Dirce pela amizade, carinho, apoio, exemplo e inspiração que sempre me deram. 
Aos meus amores Sayuri e Aline. Vocês fazem tudo isso valer a pena, por estarem junto a mim quando preciso e por sempre acreditarem em mim.

Dedico a vocês, não só este trabalho, mas todo meu amor. 


\section{AGRADECIMENTOS}

A todos que me acompanharam pela paciência e compreensão durante a execução deste trabalho. Gostaria de citar algumas pessoas que, de forma especial, dedicaram seu tempo e conhecimento, possibilitando a realização deste trabalho.

À Profa. Dra. Martha Simões Ribeiro, meus infinitos agradecimentos pelos ensinamentos, confiança e orientação oferecidos a mim no decorrer desta importante etapa da minha vida profissional. À minha amiga Martha meu eterno agradecimento por todas as oportunidades que não seriam possíveis de serem concretizadas se você não acreditasse em mim e me desse seu apoio.

Ao Prof. Dr. Michael R. Hamblin por me acolher e permitir realizar este trabalho, disponibilizando seu laboratório e principalmente seus conhecimentos, possibilitando o engrandecimento deste trabalho.

Ao Prof. Dr. Maurício Baptista, pela oportunidade de compartilhar idéias e sugestões. Sua colaboração foi essencial para a realização deste trabalho.

Ao Prof. Dr. Nasser Daghastanli, pela sua disposição, colaboração, boa vontade e por compartilhar ideais.

À Profa. Dra. Rosangela Itri, por abrir as portas de seu laboratório e dividir seus conhecimentos.

À Profa. Dra. Denise Maria Zezell por sua colaboração desde o início.

Ao Prof. Dr. Niklauss Ursus Wetter por sua colaboração e pelas idéias sugeridas. Seus conselhos jamais serão esquecidos. 
Ao Prof. Dr. Gessé Eduardo Calvo Nogueira brilhante pesquisador e pessoa exemplar, para todos que convivemos com você.

Ao Prof. Dr. Nilson Dias Vieira Júnior, pelo exemplo e pela oportunidade de trabalhar no Centro de Lasers e Aplicações.

À Profa. Dra. Silvia C. Núñez, por sua dedicação e incentivo, meus eternos agradecimentos. À minha grande amiga Silvia, companheira de trabalho, incentivadora e exemplo de pesquisadora. Não poderia existir pessoa melhor para compartilhar esta jornada.

À Dra. Cíntia C. Santos e ao Dr. Ricardo Matsumoto por sua amizade e colaboração, dentro e fora da Odontologia.

À Profa. Dra. e amiga Daniela de Fátima Teixeira da Silva, por estar sempre próxima e disposta a colaborar com suas idéias e companheirismo dentro e fora da física.

Ao Prof. Dr. e amigo Anderson Zanardi de Freitas, pela colaboração, pelas discussões e apoio.

À Helena Junqueira, pela paciência e colaboração.

A todos meus colegas de laboratório que sempre acreditaram e torceram pelos bons resultados desta pesquisa. Ao Aécio, Karin, China, Renato, Cris, Tatiana, Stella, Ricardo, Daniel e às nossas queridas agregadas Ilka e Melissa, pela colaboração, incentivo e pelos bons momentos vividos no escritório.

A todos os colegas desta jornada, Valdir, Luciano, Walter, Adriana, Cassius, Patrícia, Renata, Claudinha, Thiago, Felipe, Carol, meu muito obrigado. 
Aos colegas do laboratório na Universidade de Harvard que me receberam e me apoiaram; George, Pawel, Ana, Marina, Tianhong e Tatiana, obrigado pelos momentos juntos e pela acolhida em Boston.

A todos os professores do CLA, pela ajuda e colaboração.

Aos funcionários do CLA, sempre tão atenciosos.

Ao IPEN, pela infra-estrutura oferecida, que possibilitou a execução deste trabalho.

A todos os funcionários da divisão de ensino do IPEN.

Ao CNPq, pelo auxílio financeiro.

Finalmente, aos meus amigos e aos que não são tão amigos assim, aos que acreditaram e aos que duvidaram deste trabalho, pois cada um à sua maneira, me incentivou e continua incentivando o meu crescimento profissional e pessoal.

A todos vocês, meu muito obrigado! 


\title{
Mecanismos da Terapia Fotodinâmica em presença de $\mathrm{H}_{2} \mathrm{O}_{2}$
}

\author{
Aguinaldo Silva Garcez Segundo
}

\section{RESUMO}

A terapia fotodinâmica antimicrobiana é uma promissora alternativa para sanificação de tecidos infectados. Entretanto, esta modalidade terapêutica apresenta diferenças quanto à sua eficiência sobre diferentes microrganismos, de acordo com sua morfologia e fisiologia. A associação de $\mathrm{H}_{2} \mathrm{O}_{2}$ e PDT pode aumentar a eficiência de ambos os tratamentos, principalmente em infecções provocadas por microrganismos Gram negativos. O objetivo deste trabalho é investigar o efeito antimicrobiano sinérgico existente na reação fotodinâmica em presença do peróxido de hidrogênio e esclarecer os mecanismos envolvidos neste processo fotobioquímico. O efeito fotodinâmico foi avaliado, in vitro, através da redução microbiana de três microrganismos: Staphylococcus aureus, Pseudomonas aeruginosa e Candida albicans na presença e ausência de $\mathrm{H}_{2} \mathrm{O}_{2}$, resultando no aumento de eficiência quando associada ao $\mathrm{H}_{2} \mathrm{O}_{2}$. Para elucidar os mecanismos envolvidos no aumento da redução microbiana observada, foram avaliadas, por detecção direta e indireta, a produção de superóxido, radical hidroxila e oxigênio singleto na presença de $\mathrm{H}_{2} \mathrm{O}_{2} \mathrm{e}$ em sua ausência. Os resultados mostraram que na presença de $\mathrm{H}_{2} \mathrm{O}_{2}$ ocorre uma supressão nos mecanismos fotoquímicos, resultado em uma menor produção de espécies reativas de oxigênio. Comparando-se a redução bacteriana em Escherichia coli provocada pelo uso das terapias em separado, ou agindo em conjunto, e confrontando a quantidade de fotossensibilizador captado pelo microrganismo após condicionamento com $\mathrm{H}_{2} \mathrm{O}_{2}$ e após PDT, os resultados indicam que os mecanismos de ação da associação PDT e $\mathrm{H}_{2} \mathrm{O}_{2}$ podem ser bioquímicos. Os resultados obtidos mostram que em associação com $\mathrm{H}_{2} \mathrm{O}_{2}$, a PDT antimicrobiana tem sua eficiência aumentada, produzindo maior redução microbiana em diferentes microrganismos, entretanto, a dinâmica de formação de espécies reativas de oxigênio na presença do peróxido mostrou menor eficiência, tanto para reação tipo I como para reação tipo II. A avaliação dos mecanismos bioquímicos envolvidos neste processo mostra que há um aumento da captação do fotossensibilizador pelo microrganismo após condicionamento prévio da célula com $\mathrm{H}_{2} \mathrm{O}_{2}$. 


\title{
Mechanisms of Photodynamic Therapy in the presence of $\mathrm{H}_{2} \mathrm{O}_{2}$ \\ Aguinaldo Silva Garcez Segundo
}

\begin{abstract}
Antimicrobial photodynamic therapy is a promising approach for tissue disinfection. However, this therapy does not have the same efficiency over different microorganisms, according to their morphology and physiology. The use of PDT associated to $\mathrm{H}_{2} \mathrm{O}_{2}$ could be able to improve the efficiency of both therapies and achieve better results, mainly over Gram negative infections. The aim of this study is to demonstrate the antimicrobial effect in the photodynamic reaction in the presence of $\mathrm{H}_{2} \mathrm{O}_{2}$ and clarify the mechanisms involved in this photo-chemical-biological process. The photodynamic process was evaluated, in vitro, through the microbial killing of Staphylococcus aureus, Pseudomonas aeruginosa and Candida albicans in the presence and absence of $\mathrm{H}_{2} \mathrm{O}_{2}$. The association resulted in an improvement of the phototherapy when it was associated with $\mathrm{H}_{2} \mathrm{O}_{2}$. To elucidate the mechanisms responsible for the more efficient microbial killing, the process was directly and indirectly evaluated regard to the production of superoxide, hydroxyl radicals and singlet oxygen when the photosensitizer was in $\mathrm{H}_{2} \mathrm{O}$ or $\mathrm{H}_{2} \mathrm{O}_{2}$ solution. The results showed that in the presence of $\mathrm{H}_{2} \mathrm{O}_{2}$, the photo-chemical process was decreased and the production of reactive oxygen species was lower than expected. Comparing the microbial killing of Escherichia coli using the therapies alone or together and facing to the photosensitizer uptake after $\mathrm{H}_{2} \mathrm{O}_{2}$ incubation, the results indicated a biochemical mechanism instead a photochemical improvement. The data demonstrated that the association of $\mathrm{H}_{2} \mathrm{O}_{2}$ and antimicrobial PDT achieved higher microbial reduction over different microorganisms, but conversely than expected, the production of reactive oxygen species in the presence of $\mathrm{H}_{2} \mathrm{O}_{2}$ was lower for type I reaction and also for type II reaction. The evaluation of the biochemical mechanisms involved in this association showed an improvement in the photosensitizer uptake after previous conditioning of the cell with $\mathrm{H}_{2} \mathrm{O}_{2}$.
\end{abstract}




\section{LISTAS DE FIGURAS E GRÁFICOS E TABELAS}

Tabela 1 - Média da quantidade de $\mathrm{O}_{2}$ dissolvido nos solventes analisados

Gráfico 1: Média e desvio padrão da redução microbiana resultante da toxicidade intrínseca de cada fotossensibilizador

Tabela 2: Média e desvio padrão da redução microbiana resultante da toxicidade intrínseca do fotossensibilizador

Gráfico 2: Média e desvio padrão da redução microbiana resultante da toxicidade intrínseca do fotossensibilizador e do peróxido de hidrogênio

Tabela 3: Média e desvio padrão da redução microbiana resultante da toxicidade intrínseca do fotossensibilizador e do peróxido de hidrogênio

Gráfico 3: Média e desvio padrão da redução microbiana de S. aureus resultante da toxicidade do azul de metileno em solução de $\mathrm{H}_{2} \mathrm{O}_{2}$ e da PDT na ausência e na presença de três concentrações de $\mathrm{H}_{2} \mathrm{O}_{2}$

Tabela 4: Média e desvio padrão da redução microbiana de $S$. aureus resultante da toxicidade do azul de metileno em solução de $\mathrm{H}_{2} \mathrm{O}_{2}$ e da PDT na ausência e na presença de três concentrações de $\mathrm{H}_{2} \mathrm{O}_{2}$

Gráfico 4: Média e desvio padrão da redução microbiana de $P$. aeruginosa resultante da toxicidade do azul de metileno em solução de $\mathrm{H}_{2} \mathrm{O}_{2}$ e da PDT na ausência e na presença de três concentrações de $\mathrm{H}_{2} \mathrm{O}_{2}$

Tabela 5: Média e desvio padrão da redução microbiana de $P$. aeruginosa resultante da toxicidade do azul de metileno em solução de $\mathrm{H}_{2} \mathrm{O}_{2}$ e da PDT na ausência e na presença de três concentrações de $\mathrm{H}_{2} \mathrm{O}_{2}$

Gráfico 5: Média e desvio padrão da redução microbiana de C.albicans resultante da toxicidade do azul de metileno em solução de $\mathrm{H}_{2} \mathrm{O}_{2}$ e da PDT na ausência e na presença de três concentrações de $\mathrm{H}_{2} \mathrm{O}_{2}$

Tabela 6: Média e desvio padrão da redução microbiana de C.albicans resultante da toxicidade do azul de metileno em solução de $\mathrm{H}_{2} \mathrm{O}_{2}$ e da PDT na ausência e 
na presença de três concentrações de $\mathrm{H}_{2} \mathrm{O}_{2}$

Gráfico 6: Média e desvio padrão da redução microbiana de S. aureus resultante da toxicidade do conjugado a base de clorina em solução de $\mathrm{H}_{2} \mathrm{O}_{2}$ e da PDT na ausência e na presença de três concentrações de $\mathrm{H}_{2} \mathrm{O}_{2}$

Tabela 7: Média e desvio padrão da redução microbiana de S. aureus resultante da toxicidade do conjugado a base de clorina em solução de $\mathrm{H}_{2} \mathrm{O}_{2}$ e da PDT na ausência e na presença de três concentrações de $\mathrm{H}_{2} \mathrm{O}_{2}$

Gráfico 7: Média e desvio padrão da redução microbiana de $P$. aeruginosa resultante da toxicidade do conjugado a base de clorina em solução de $\mathrm{H}_{2} \mathrm{O}_{2}$ e da PDT na ausência e na presença de três concentrações de $\mathrm{H}_{2} \mathrm{O}_{2}$

Tabela 8: Média e desvio padrão da redução microbiana de $P$. aeruginosa resultante da toxicidade do conjugado a base de clorina em solução de $\mathrm{H}_{2} \mathrm{O}_{2}$ e da PDT na ausência e na presença de três concentrações de $\mathrm{H}_{2} \mathrm{O}_{2}$

Gráfico 8: Média e desvio padrão da redução microbiana de C. albicans resultante da toxicidade do conjugado a base de clorina em solução de $\mathrm{H}_{2} \mathrm{O}_{2}$ e da PDT na ausência e na presença de três concentrações de $\mathrm{H}_{2} \mathrm{O}_{2}$

Tabela 9: Média e desvio padrão da redução microbiana de C. albicans resultante da toxicidade do conjugado a base de clorina em solução de $\mathrm{H}_{2} \mathrm{O}_{2}$ e da PDT na ausência e na presença de três concentrações de $\mathrm{H}_{2} \mathrm{O}_{2}$

Gráfico 9: Formação de oxigênio singleto pela irradiação do azul de metileno e azul de metileno associado a $\mathrm{H}_{2} \mathrm{O}_{2}$

Gráfico 10: Formação de oxigênio singleto pela irradiação do conjugado a base de clorina e deste fotossensibilizador associado a $\mathrm{H}_{2} \mathrm{O}_{2}$

Gráfico 11: Formação de oxigênio singleto pela irradiação do conjugado a base de clorina e deste fotossensibilizador associado a $\mathrm{H}_{2} \mathrm{O}_{2}$

Gráfico 12: Formação de superóxido pela irradiação do azul de metileno e deste fotossensibilizador associado a $\mathrm{H}_{2} \mathrm{O}_{2}$

Gráfico 13: Formação de superóxido pela irradiação do conjugado a base de 
clorina e da associação deste fotossensibilizador a $\mathrm{H}_{2} \mathrm{O}_{2}$

Gráfico 14: Formação de radical hidroxila pela irradiação do azul de metileno e deste fotossensibilizador associado a $\mathrm{H}_{2} \mathrm{O}_{2}$

Gráfico 15: Formação de radical hidroxila pela irradiação do conjugado a base de clorina e deste fotossensibilizador associado a $\mathrm{H}_{2} \mathrm{O}_{2}$

Figura 1: Suspensão de $C$. albicans carregada de DCFH na presença de AM

Figura 2: Suspensão de $C$. albicans carregada de $\mathrm{DCFH}$ na presença de $\mathrm{AM}+\mathrm{H}_{2} \mathrm{O}_{2}$

Gráfico 16: Formação de espécies reativas de oxigênio pela irradiação do azul de metileno e deste fotossensibilizador associado a $\mathrm{H}_{2} \mathrm{O}_{2}$ no interior do fungo $C$. albicans

Gráfico 17: Espectroscopia de absorção do azul de metileno remanescente na solução após centrifugação e remoção das células

Gráfico 18: Captação de FS no interior das células avaliada pela intensidade de fluorescência do FS a base de clorina

Gráfico 19: Médias e desvio padrão da redução microbiana após diferentes seqüências de tratamento utilizando o azul de metileno como fotossensibilizador

Tabela 10: Médias e desvio padrão da redução microbiana após diferentes seqüências de tratamento utilizando o azul de metileno como fotossensibilizador

Gráfico 20: Médias e desvio padrão da redução microbiana após diferentes seqüências de tratamento utilizando o conjugado a base de clorina como fotossensibilizador

Tabela 11: Médias e desvio padrão da redução microbiana após diferentes seqüências de tratamento utilizando o conjugado a base de clorina como fotossensibilizador 


\section{LISTA DE SÍMBOLOS, SIGLAS E ABREVIATURAS}

ALA - ácido aminolevulínico

AM - azul de metileno

AT - azul de toluidina

$\mathrm{BHI}$ - Brain and Heart Infusion

${ }^{\circ} \mathrm{C}$ - graus Celsius

cm - centímetro

$\mathrm{cm}^{2}$ - centímetro quadrado

DCFH-DA - diacetato de diclorifluoresceína

DCF - diclorofluoresceína

DNA - ácido desoxirribonucléico

ERO - espécies reativas de oxigênio

FDA - Food and Drug Administration

Fe - ferro

FS - fotossensibilizador

g - gramas

GaAlAs - arseneto de gálio e alumínio

He-Ne - Hélio-Neônio

$\mathrm{H}_{2} \mathrm{O}_{2}$ - peróxido de hidrogênio

$\mathrm{J}$ - joule

$\mathrm{J} / \mathrm{cm}^{2}$ - joule por centímetro quadrado 
LED - Light Emmiting Diode (Diodo Emissor de Luz)

M - molar

$\mathrm{mg} / \mathrm{kg}$ - miligramas por quilo

$\mathrm{mM}$ - milimolar

mm - milímetro

mW - miliwatt

$\mathrm{NADPH}$ - nicotinamida-adenina-dinucleotídeo-fosfato reduzida

$\mathrm{NaOH}$ - hidróxido de sódio

NBT - cloreto azul de nitrotetrazolium

$\mathrm{nm}$ - nanometro

PACT - Photodynamic Antimicrobial Chemotherapy (quimioterapia fotodinâmica antimicrobiana)

PBS - Phosphate Buffer Saline (solução salina tamponada com fosfato)

PDT - Photodynamic Therapy (terapia fotodinâmica)

RNO - N,N dimetil-4-notrosoanilina

rpm - rotações por minuto

$s-$ segundos

ufc - unidades formadoras de colônias

W - watt

$\mu \mathrm{g} / \mathrm{ml}$ - microgramas por mililitro

$\mu \mathrm{L}-$ microlitro

$\lambda$ - comprimento de onda 


\section{SUMÁRIO}

RESUMO

ABSTRACT

LISTA DE FIGURAS, GRÁFICOS E TABELAS

iii

LISTA DE SÍMBOLOS, SIGLAS E ABREVIATURAS

vi

1- INTRODUÇÃO

01

2- OBJETIVOS

3- REVISÃO DA LITERATURA

06

4- MATERIAIS E MÉTODOS

26

5- RESUltAdos

38

6- DISCUSSÃO

63

7- ESTUDOS FUTUROS ADICIONAIS

72

CONCLUSÃO

73

REFERÊNCIAS BIBLIOGRÁFICAS 


\section{1 - INTRODUÇÃO}

Desde a descoberta do efeito fotodinâmico por Raab e von Taippener em 1900, sabe-se que diversos microrganismos podem ser eliminados pela associação de um fotossensibilizador não tóxico e uma fonte de luz ressonante. A Terapia Fotodinâmica (PDT) consiste na associação de um agente fotossensibilizante, normalmente exógeno, e uma fonte de luz, com o objetivo de provocar morte (necrose ou apoptose) celular, utilizada em tratamento de tumores e morte microbiana.

O mecanismo de ação se dá quando o agente fotossensibilizante absorve os fótons da fonte de luz e seus elétrons passam a um estado excitado. Na presença de um substrato, como por exemplo o oxigênio, o fotossensibilizador ao retornar ao seu estado fundamental, transfere a energia ao substrato, formando espécies de vida curta e altamente reativas, como o oxigênio singleto, superóxidos e outros radicais livres de alta citotoxicidade, que podem provocar sérios danos ao microrganismos, via oxidação irreversível de componentes celulares. Vários autores relatam danos à membrana celular, às mitocôndrias e ao núcleo celular. ${ }^{1,2}$

Apesar da descoberta da PDT ter ocorrido através de uma ação antimicrobiana, esta terapia tem sido utilizada, desde então, no tratamento de tumores. Entretanto, o rápido aumento do aparecimento de microrganismos resistentes a antibióticos, devido à automedicação ou prescrição inapropriada, um crescente interesse mundial tem surgido por terapias alternativas. A redução microbiana por PDT tem se mostrado eficiente em diversos microrganismos, mesmo nos que apresentam múltipla resistência a 
antibióticos. A além disto, a PDT não apresenta até o presente momento indícios de que microrganismos possam desenvolver mecanismos de resistência à este tratamento. ${ }^{3}$

Por outro lado, a redução microbiana por efeito fotodinâmico, apesar de eficiente em diversas espécies, enfrenta desafios diferentes quando utilizada contra bactérias Gram positivas (Gram+), bactérias Gram negativas (Gram-), esporos bacterianos e fungos. ${ }^{4}$ De maneira geral, a literatura mostra que as bactérias Gram+ podem ser eliminadas por vários fotossensibilizadores e doses mais baixas de irradiação, do que bactérias Gram-, bactérias esporuladas e fungos. Isso se deve a diferenças estruturais nas membranas celulares destes microrganismos, e no caso do fungos, devido ao maior volume do mesmo. ${ }^{4,5}$

As fenotiazinas, corantes dos quais faz parte o Azul de Metileno (AM), têm sido bastante empregadas para terapia fotodinâmica antimicrobiana ${ }^{1,6,7,8,9,10}$. Este fotossensibilizador possui estrutura linear tricíclica e heteroaromática, e assim como outros fotossensibilizadores, as fenotiazinas são mais efetivas contra bactérias Gram+ do que outros microrganismo e possuem uma marcante ação contra vírus ${ }^{4,11}$ sendo utilizado em serviços de esterelização sanguínea, principalmente na Europa, para foto-desinfecção de plasma e sangue..$^{12,13}$

O peróxido de hidrogênio tem sido utilizado como agente antimicrobiano e antisséptico, em diversas áreas da Saúde, tanto humana como animal. Este composto age como um radical livre e forte agente oxidante, podendo matar microrganismos por danos ao DNA ${ }^{14}$. 
A maior parte da ação fotodinâmica se apóia na tríade: fotossensibilizador, fonte de luz e presença de oxigênio; portanto, com o objetivo de potencializar sua ação, diversas variáveis já foram investigadas como: fracionamento da dose de $l u z^{15}$, concentração e agregação do fotossensibilizador, irradiância da fonte luminosa, entre outros ${ }^{16}$. A associação da PDT antimicrobiana e peróxido de hidrogênio para potencializar a morte microbiana já foi comprovada em trabalhos anteriores de nosso grupo e por outros trabalhos da literatura; entretanto, seu mecanismo ainda não foi devidamente compreendido. 


\section{2 - OBJETIVOS GERAIS}

O efeito fotodinâmico ocorre e depende, parcialmente, da presença de oxigênio molecular. Portanto, a ação fotodinâmica poderia ter sua eficiência aumentada na presença de $\mathrm{H}_{2} \mathrm{O}_{2}$, devido à instabilidade deste composto e por sua molécula ser facilmente decomposta em $\mathrm{O}_{2}$ e $\mathrm{H}_{2} \mathrm{O}$. O aumento de $\mathrm{O}_{2}$ disponível no meio poderia facilitar a formação de espécies reativas de oxigênio (ERO), intensificando a morte microbiana.

Para tanto, os objetivos deste trabalho são: avaliar a redução microbiana por efeito fotodinâmico, na presença e ausência de $\mathrm{H}_{2} \mathrm{O}_{2}$ em diferentes microrganismos (bactérias Gram+, Gram- e fungos), utilizando dois diferentes FS e determinar os possíveis mecanismos envolvidos na reação fotodinâmica na presença de $\mathrm{H}_{2} \mathrm{O}_{2}$.

Os objetivos específicos são:

- Investigar a concentração de $\mathrm{O}_{2}$ na água destilada e em $\mathrm{H}_{2} \mathrm{O}_{2}$

- Investigar a redução microbiana, in vitro, utilizando o dois diferentes FS em solução aquosa ou em solução de $\mathrm{H}_{2} \mathrm{O}_{2}$

- Investigar, por detecção direta e indireta, os mecanismos fotofísicos e fotoquímicos da formação de ERO, por ação fotodinâmica, em solução aquosa ou em solução de $\mathrm{H}_{2} \mathrm{O}_{2}$

- Investigar os mecanismos fotofísicos e fotoquímicos da formação de ERO, por ação fotodinâmica, no interior de células, quando estas foram tratadas com FS em solução aquosa ou em solução de $\mathrm{H}_{2} \mathrm{O}_{2}$

- Investigar a captação do FS pela célula após condicionamento com $\mathrm{H}_{2} \mathrm{O}_{2}$ 
- Investigar os mecanismos bioquímicos de morte microbiana, alterando a seqüência em que o microrganismo foi submetido à ação do FS, PDT ou do $\mathrm{H}_{2} \mathrm{O}_{2}$ 


\section{3 - REVISÃO DA LITERATURA}

\section{1 - Terapia Fotodinâmica Antimicrobiana}

\subsection{1 - Histórico e microrganismos susceptíveis}

O primeiro relato do uso de luz associada a um fotossensibilizador para a morte de microrganismos se deve a Raab e von Tappeiner, em 1900, quando os mesmos pesquisavam o efeito da acridina sobre cultura de paramécios. Os pesquisadores notaram que devido às condições não usuais de luminosidade no ambiente durante a realização do experimento, a associação de luz e da acridina foi letal para estes microrganismos.

Também em 1900, o neurologista francês Prime estava estudando os efeitos da administração oral de eosina em pacientes com epilepsia. O médico notou que um dos efeitos colaterais era o aparecimento de dermatite na pele dos pacientes expostos ao sol. Baseados nestas descobertas, von Tappeiner e

o dermatologista Joudlbauer utilizaram a combinação de eosina tópica e luz branca para o tratamento de câncer de pele e, em 1907, estes pesquisadores publicaram um trabalho propondo o termo "Ação Fotodinâmica" para esta nova modalidade de tratamento. Os autores descrevem, já neste trabalho, a importância do oxigênio nas reações de fotossensibilização.

A busca por novos agentes fotossensibilizantes levou à descoberta de um grupo de substâncias conhecidas como porfirinas. Um destes compostos foi utilizado por Hausmann em 1911 para demonstrar o efeito letal da associação de hematoporfirina e luz branca sobre microrganismos, células sanguíneas e pele de rato. Estes achados fizeram com que diversos pesquisadores passassem a estudar fotossesibilizadores para utilização em oncologia e não mais no combate a microrganismos. 
Os estudos seguintes com as porfirinas mostraram que a hematoporfirina e seus derivados era uma nova e importante ferramenta no diagnóstico e tratamento de tumores. Em 1975, Dougherty e colaboradores apresentaram o primeiro caso de sucesso na cura total de tumores em experimentos em animais. $^{17}$

Outro fator que levou ao desinteresse pela PDT antimicrobiana foi a descoberta na década de 40 da penicilina e, principalmente, o uso em larga escala dos antibióticos durante a II Guerra Mundial. Estes medicamentos deram aos pesquisadores das áreas da Saúde a falsa impressão de que a batalha contra os microrganismos estava vencida. Entretanto, dois anos após o lançamento comercial da penicilina, foi relatado o aparecimento de cepas de microrganismos resistentes a esta medicação. O rápido e emergente aumento do número de bactérias patogênicas resistentes a antibióticos tem levado a uma crise mundial no tratamento de infecções. O aparecimento de cepas bacterianas multi-resistentes aos antibióticos pode estar levando ao fim, um período de tempo que compreende as últimas 4 décadas, conhecido como a "Era dos Antibióticos". Isso tem levado os pesquisadores a concluir que um novo e alternativo mecanismo de ação antimicrobiana, com efeitos colaterais mínimos e, principalmente, que não leve ao surgimento de microrganismos resistentes, seja altamente desejável neste momento. ${ }^{18,19,20}$

Durante a década de 90, como alternativa aos métodos convencionais de tratamento para infecções, diversos pesquisadores voltaram sua atenção ao uso da terapia fotodinâmica na redução microbiana.

Dobson e Wilson ${ }^{21}$, em 1992, analisaram in vitro a redução bacteriana de bactérias orais Gram+ e Gram- por fotossensibilização de biofilme formado 
pelas espécies Actinobacillus actinomycetemcomitans, Streptococcus sanguis, Fusobacterium nucleatum e Porphyromonas gingivalis. Utilizando uma associação de diversos corantes e um laser de He-Ne em baixa intensidade, os autores concluíram que os FS azul de toluidina (AT) e azul de metileno (AM) foram eficazes em eliminar as quatro espécies de bactérias. Os FS ftalocianina dissulfonada de alumínio, hematoporfirina e hematoporfirina éster somente foram efetivos em sensibilizar alguns dos microrganismos. Os autores sugerem que a terapia fotodinâmica pode ser efetiva em eliminar bactérias periodontopatogênicas da placa bacteriana.

Wilson et al, também em $1992^{22}$, testaram in vitro, vinte e sete compostos associados ao laser de He-Ne e sua capacidade de sensibilizar e eliminar as bactérias $A$. actinomycetemcomitans e $P$. gingivalis. Os corantes AT, AM e cloreto azul B nas concentrações de $0,005 \%$ foram efetivos contra as quatro espécies de bactérias, quando associados a um tempo de exposição de apenas $30 \mathrm{~s}$.

Wilson et al, em $1993^{23}$, testaram in vitro diversos corantes na fotossensibilização de $S$. sanguis. Culturas da bactéria foram expostas a um laser de He-Ne em diferentes tempos de irradiação e associado a diferentes FS. Os resultados obtidos pela contagem de unidades formadoras de colônias (ufc) viáveis mostraram que o AT, hematoporfirina éster, tionina e o AM foram eficazes em matar o microrganismo. Entretanto, verificou-se que os corantes hematoporfirina éster e AM eram tóxicos ao microrganismo na ausência do laser e que os corantes ftalocianina dissulfonada de alumínio e cristal violeta foram ineficazes nas condições utilizadas no estudo. 
Já idealizando uma aplicação clínica dos achados de Wilson e colaboradores, em 1996, Soukos et al ${ }^{24}$ avaliaram os efeitos fotodinâmicos in vitro da radiação laser vermelha e do AT sobre queratinócitos orais humanos, fibroblastos e S. sanguis. O objetivo do trabalho foi avaliar o risco que a PDT representa para as células normais do paciente, isto é, se era possível eliminar as bactérias causadoras da lesão, sem provocar danos aos tecidos adjacentes. Os autores concluíram que o uso de baixas concentrações de FS associadas ao laser em baixa intensidade provocava a morte bacteriana e não reduzia a viabilidade celular, indicando a segurança desta terapia para uso clínico.

Sailer et al, em $1997^{25}$, correlacionaram a inativação fotodinâmica da bactéria Pseudomonas aeruginosa com a biossíntese de porfirina após incubação com ácido 5-aminolevulínico (ALA). Os autores verificaram a formação de porfirina endógena por espectroscopia de fluorescência e pela técnica de cromatografiade líquida de alta performance e sugerem que a incubação com o ALA aumenta o acúmulo de protoporfirinas.

Walsh ${ }^{26}$, revisando a literatura sobre o uso dos lasers em baixa intensidade em tecidos duros orais, descreveu a fotossensibilização de bactérias com o uso associado de lasers em baixa intensidade e FS apropriados, com absorção ressonante à emissão do laser. $\mathrm{O}$ autor sugeriu que esta técnica poderia ter aplicação potencial para redução bacteriana no interior de canais radiculares e bolsas periodontais como coadjuvante ao tratamento convencional.

Os estudos nesta área, principalmente na redução bacteriana de microflora oral, vinham ganhando importância na literatura e Wainwrigth, em $1998^{4}$, em um artigo de revisão da literatura, apresentou os mecanismos de 
ação da terapia fotodinâmica sobre microrganismos, os diversos FS em uso, com destaque especial aos FS da classe das fenotiazinas, como o AM e AT. Apresentou também as perspectivas futuras da técnica e propôs o termo photodynamic antimicrobial chemoteraphy (PACT) ou Quimioterapia Fotodinâmica Antimicrobiana, diferenciando esta técnica da Terapia Fotodinâmica para o tratamento de tumores.

Novos fotossensibilizadores estavam sendo estudados por diversos grupos ao redor do mundo e em 1998, Soukos estudou a associação de uma clorina (ce6) e uma poli-L-lisina para a terapia fotodinâmica antimicrobiana. O objetivo deste trabalho era testar a hipótese de que este composto seria mais eficiente na fotodestruição de bactérias orais Gram+ e Gram-, com mínimos efeitos deletérios a uma linhagem de células epiteliais. Os resultados mostraram que para a $P$. gingivalis o uso de composto fotossensibilizador com carga catiônica resultou em redução bacteriana de 99\%, o conjugado com carga neutra $95 \%$ e o de carga aniônica apresentou apenas $76 \%$ de redução. Para o Actinimyces Viscousis, o conjugado catiônico apresentou redução de 99,99\%, enquanto que a linhagem de células epiteliais (HCPC-1) permaneceu intacta. Os autores explicaram este resultado apontando que a captação seletiva do conjugado pela bactéria é significativamente maior (20 a 100 vezes) do que a captação pela célula. A clorina sozinha possui uma seletividade muito menor (5 a 20 vezes) comparada à mesma linhagem de células epiteliais ${ }^{27}$.

Estudando microrganismos mais complexos do que bactérias procariontes, Jackson et al ${ }^{28}$ investigaram, in vitro, a morte microbiana de Candida albicans (um fungo eucarionte) nas suas formas de levedura e hifa . Os autores utilizaram um laser de He-Ne em baixa intensidade, associado ao 
corante AT. Avaliou-se nesse trabalho a concentração do corante, a energia de aplicação do laser e o tempo que o FS leva para ser absorvido pelo fungo (tempo de pré-irradiação). Os autores concluíram que a associação entre o laser e o FS resultou em substancial morte microbiana tanto na forma de hifa quanto na de levedura. Além disso, a morte microbiana é energia dependente e o tempo ótimo de pré-irradiação é o de 5 minutos para a forma de levedura, pois a forma de hifa não é influenciada pelo tempo de pré-irradiação. Este experimento mostrou que diferentes microrganismos respondem de maneira particular à PDT e que a adequação dos parâmetros utilizados é uma condição necessária à redução microbiana para diferentes espécies.

Já nos anos 2000, os estudos de diferentes FS e diferentes fontes de luz continuavam a ser um assunto recorrente nas pesquisas, mas estes deixavam de ser experimentos laboratoriais em placas de Petri para começarem a ser estudos em condições mais próximas da clínica, como estudos em animais. Kawamoto et al ${ }^{29}$ estudaram, in vivo, o efeito antibacteriano do laser de $\mathrm{He}-\mathrm{Ne}$ de emissão amarela associado ao corante violeta cristal em abscessos subcutâneos em rato provocados pela bactéria $P$. gingivalis. Após uma semana, as amostras dos locais onde foram inoculados os cones de papel infectados foram analisadas histologicamente. Os resultados mostraram que 0 número de células inflamatórias foi grande nos grupos FS e bactéria, foi menor no grupo laser e menor ainda no grupo controle, onde não foi inoculada a bactéria.

Mostrando um amadurecimento nesta terapia, Silbert et al ${ }^{30}$ avaliaram, in vitro, o potencial da terapia fotodinâmica em reduzir a contaminação bacteriana em canais radiculares, em uma situação prévia ao uso clínico, já 
antevendo as adequações desta terapia a uma situação real de uso. Uma série de canais radiculares foi preparada por instrumentação mecânica. As raízes dos dentes, após serem esterilizadas, foram divididas em dois grupos e contaminadas. Um dos grupos recebeu intra-radicularmente uma solução de cultura de Streptococcus mutans e o outro grupo uma solução de cultura de Enterococcus faecalis. Os autores utilizaram um laser de diodo de $\operatorname{lnGaAIP}(\lambda=$ $670 \mathrm{~nm}$ e de $3.5 \mathrm{~mW}$ de potência), com sistema de entrega por fibra óptica de diâmetro $600 \mu \mathrm{m}$, associado ao corante AM. As raízes foram irradiadas por períodos de tempo que variaram de 30 s a 240 s. Os resultados mostraram que o corante sozinho conseguiu redução bacteriana de $20 \%$; somente a irradiação laser não alterou a população bacteriana. A irradiação laser provocou um aumento de temperatura que não foi superior a $0,5^{\circ} \mathrm{C}$. $\mathrm{O}$ corante associado à irradiação laser por 240s eliminou todas as bactérias do grupo de raízes contaminado com S. mutans, entretanto, o mesmo tempo de irradiação somente conseguiu eliminar $40 \%$ das bactérias dos canais contaminados com E. faecalis. Os autores concluíram que a PDT pode ser um efetivo método de redução bacteriana intracanal, porém, os parâmetros devem ser ajustados para que se consiga a eliminação de bactérias como E. faecalis.

Em 2006, Maisch ${ }^{31}$ alertou sobre o aumento do número de microrganismos resistentes a antibióticos e que novas terapias deveriam ser desenvolvidas em um futuro próximo, sugerindo que a PDT antimicrobiana poderia ser uma alternativa ao uso de antibióticos e antimicrobianos, principalmente em aplicações tópicas. O autor revisou a literatura e indicou que áreas como dermatologia, no tratamento de feridas infectadas (principalmente com cepas resistentes de Staphylococcus), acne, psoríases e infecções 
cutânes por fungo; em gastroenterologia, para o tratamento de úlceras gástricas provocas por Heliobacter pylori e em odontologia para a redução microbiana de microrganismos relacionados à cárie, doença periodontal e periimplantites, a PDT antimicrobiana já é considerada uma promissora nova modalidade de tratamento.

Garcez e colaboradores ${ }^{32}$, em 2007, utilizando o conjugado do fotossensibilizador clorina(e6) e polietilenemina (PEI) e um laser de diodo de $\lambda=$ 660nm, compararam a redução microbiana alcançada pelo tratamento endodôntico convencional (preparo químico-mecânico), pela PDT e pela terapia endodôntica associada à PDT antimicrobiana. Os canais radiculares foram contaminados com bactérias bioluminescentes permitindo uma análise em tempo real dos resultados. Os microrganismos Pseudomonas aeruginosa e Proteus mirabilis, ambos bactérias Gram-, foram incubados por $72 \mathrm{~h}$ a $37^{\circ} \mathrm{C}$, permitindo a formação de um biofilme no interior dos canais. Os resultados mostraram que o tratamento endodôntico promoveu uma redução bacteriana de $90 \%$, a PDT reduziu $95 \%$ das bactérias e a associação dos tratamentos resultou em $98 \%$ de redução. Mais significativo do que a redução microbiana alcançada, a análise da recolonização dos canais após 24 h, mostrou que a combinação dos tratamentos foi mais efetiva que os tratamentos em separado.

\subsubsection{Fotossensibilizadores e Mecanismos}

Ovchinnikov e Tuchin ${ }^{33}$, em 2001, estudaram em situações clínicas e pré-clínicas, o uso da terapia fotodinâmica em microrganismos da cavidade oral, com capacidade de gerar lesões infecciosas. Os autores testaram 
diferentes concentrações do corante AM associado a um laser de He- $\mathrm{Ne}$ em culturas de espécies de Staphylococcus. Os autores concluíram que a concentração de $0.1 \%$ do AM foi a concentração que apresentou os melhores resultados, sem que esta concentração fosse tóxica para as bactérias ou para as células gengivais dos pacientes. Os autores preconizaram também o tempo de pré-irradiação de 3 minutos, pois, segundo eles, este tempo é clinicamente aceitável para o paciente e para o clínico. Tempos superiores a este poderiam levar a uma penetração do corante nos tecidos saudáveis, o que resultaria em danos aos tecidos sadios do paciente.

Em 2001, Usacheva e colaboradores $^{34}$ estudaram os principais fotossensibilizadores do grupo das fenotiazinas, AM e AT, quanto à sua ação bactericida na presença e na ausência de luz em bactérias Gram+ e Gram-. Utilizando-se de suspensão em solução salina de S. aureus, Streptococcus pneumoniae, E. faecalis, Haemophilus influenzae, Escherichia coli, e $P$. aeruginosa, os autores avaliaram os efeitos da concentração dos corantes, o tempo de incubação na ausência de luz, a dose de irradiação e a intensidade da fonte de luz para a morte destas espécies. Os autores concluíram que o AT foi mais efetivo, tanto na presença quanto na ausência de luz, entretanto, o AM mostrou redução bacteriana significativa em todos os microrganismos estudados.

Hamblin e colaboradores ${ }^{35}$, em 2002, avaliaram o efeito do tamanho da cadeia de polilisina conjugada ao fotossensibilizador clorina (e6) na fotodestruição de bactérias Gram+ e Gram-. Foi preparada uma solução fotossensibilizadora de clorina (e6) livre e conjugados de uma molécula de clorina (e6) ligada a oito lisinas ou a 37 lisinas. Estes conjugados foram 
incubados à suspensão de $S$. aureus e E. coli, respectivamente uma bactéria Gram+ e uma Gram-, e irradiados com um laser de diodo de $\lambda=660 \mathrm{~nm}$ com densidades de energia de 10 a $40 \mathrm{~J} / \mathrm{cm}^{2}$. Os $\mathrm{FS}$ conjugados se aderiram mais facilmente aos microrganismos, enquanto a clorina livre apenas se ligou à bactéria Gram+. Os resultados mostraram que a clorina (e6) ligada à cadeia de 37 lisinas foi efetiva na redução de E.coli. O S. aureus, por outro lado, foi morto pela clorina livre e pelos dois conjugados, sendo o FS de menor cadeia de lisinas mais eficiente para esta bactéria. Os autores sugeriram que a maior cadeia de lisinas ligada à clorina (e6) é necessária para que este FS penetre através da membrana externa das bactérias Gram-, sendo as bactérias Gram+ mais permeáveis à menor cadeia de lisina. Entretanto, como os dois microrganismos podem ser eficientemente reduzidos pelo FS ligado à cadeia de 37 lisinas, os autores indicam este FS de cadeia maior para uso em PDT antimicrobiana.

Teichert e co-autores ${ }^{36}$, em 2002, estudaram o efeito fotodinâmico do AM para o tratamento de candidíase oral induzida em camundongos imunodeprimidos. Os autores utilizaram concentrações de 250 a $500 \mu \mathrm{g} / \mathrm{mL}$ do AM, com um tempo de pré-irradiação de 10 minutos para a morte do fungo $C$. albicans. Os resultados mostraram que a morte do fungo foi dependente da concentração do fotossensibilizador. As concentrações de 450 e $500 \mu \mathrm{g} / \mathrm{mL}$ foram as que apresentaram as maiores reduções fúngicas, obtendo uma redução de aproximadamente 3 log do microrganismo e eliminando totalmente o mesmo da área tratada. Baseados nestes resultados, os autores indicaram a PDT antimicrobiana para a o tratamento da candidíase oral em pacientes imunossuprimidos. 
Usacheva e colaboradores ${ }^{37}$, em 2003 , avaliaram por espectroscopia, as interações sofridas pelos corantes AM e AT na presença de $S$. aureus, $S$. pneumoniae, E. faecalis, H. influenzae, E. coli e P. aeruginosa. Os dados obtidos mostraram uma reação metacromática dos corantes e que, na presença das bactérias, os FS tendem à formação de dímeros. Esta tendência foi maior para o AT do que para o AM. Os autores relataram também que a dimerização do FS foi maior na presença de bactérias Gram-.

Em 2004, Hamblin e Hassan ${ }^{3}$, revisando a literatura, sugeriram o uso da PDT em infecções localizadas. Os autores mostraram a atuação desta terapia em microrganismos Gram+ e Gram -. Em geral, a maior susceptibilidade das bactérias Gram+ é explicada por sua fisiologia, pois sua membrana citoplasmática é composta de peptideoglicanos relativamente porosos que permitem que o FS penetre. Por outro lado, os Gram- possuem, além da membrana citoplasmática, uma membrana externa. Esta membrana forma uma barreira física e funcional entre a célula e o ambiente protegendo estas bactérias da ação da PDT. Os autores imaginam que no futuro, com o aumento do número de pacientes imunossuprimidos, devido aos transplantes, câncer ou AIDS, terapias alternativas ao uso de antibióticos será uma tendência.

O'Riordan e colaboradores ${ }^{38}$, em 2005, revisando a literatura, mostraram que uma variedade de FS, de diferentes grupos, incluindo porfirinas, derivados de clorofila, ftalocianinas, entre outros, são eficientes na redução bacteriana, tanto em bactérias Gram+ quanto Gram- e também eficientes contra fungos e vírus. Muitos dos efeitos relatados na literatura sobre a eficiência da PDT são ainda baseados em trabalhos in vitro. Apenas um número limitado de artigos 
utilizou modelos de estudo em animais ou estudos clínicos e estes estudos reportam moderado índice de sucesso, que não condiz com a expectativa criada após os estudos in vitro. Os autores consideram que mais estudos ainda são necessários para que se entendam os mecanismos da PDT na redução microbiana

$\mathrm{Jori}^{39}$, em 2006, relata que a PDT há muito tempo tem se mostrado uma eficiente alternativa aos atuais tratamentos com antibióticos e antimicrobianos, pois estes têm falhado no combate às cepas resistentes de microrganismos. $O$ autor citou que os fatores favoráveis ao uso da PDT são: amplo espectro de ação da PDT contra diferentes microrganismos; os FS normalmente não apresentam toxicidade na ausência de luz; nas doses utilizadas, a morte microbiana se dá principalmente como conseqüência de danos à membrana do microrganismo, o que minimiza os riscos de processos mutagênicos e aparecimento de cepas resistentes; a PDT age de maneira igual sobre microrganismos naturais e cepas resistentes dos mesmos e uma combinação da terapia convencional e PDT é perfeitamente possível.

Em 2006, Tegos e co-autores ${ }^{40}$ estudaram uma segunda geração do conjugado entre clorina (e6) e polietilenemina em três diferentes formas moleculares: um conjugado em pequena cadeia linear, um conjugado em pequena cadeia de ligação cruzada e um conjugado de grande cadeia de ligação cruzada. Os FS foram avaliados por cromatografia líquida de alta performance e por sua eficiência em matar diferentes microrganismos: bactérias Gram+ (S. aureus e Streptococcus pyogenes), bactérias Gram- (E. coli e $P$. aeruginosa) e o fungo $C$. albicans. Após exposição à luz em baixa intensidade, as moléculas maiores de ligações cruzadas reduziram 
eficientemente todos os microrganismos, enquanto as moléculas lineares não mataram as bactérias Gram-. Em relação aos conjugados de primeira geração compostos por polilisinas, os conjugados de polietilenimina foram mais resistentes à degradação por proteases como a tripsina. Estes resultados, segundo os autores, sugerem que a segunda geração de conjugados é superior aos conjugados à base de polilisina para PDT antimicrobiana. Nesse trabalho, os autores se basearam no trabalho de Kralic and Mohsni ${ }^{41}$ que, em 1978, descreveram um novo método para deteç̧ão de oxigênio singleto em solução aquosa. De forma sucinta, este método detecta a produção desta espécie reativa de oxigênio, através da análise da atenuação da densidade óptica da solução em $\lambda=440 \mathrm{~nm}$, como conseqüência da degradação do N,N dimetil-4-notrosoanilina (RNO) na presença de L-histidina, utilizando um espectrofotômetro. Para a detecção indireta da reação fotodinâmica do tipo I com a formação de radicais livres do tipo superóxido, os autores utilizaram o método proposto por Yamakoshi e colaboradores em $2003^{42}$, detectando o superóxido através da análise do aumento da densidade óptica da solução contento o fotossensibilizador em $\lambda=580 \mathrm{~nm}$, como conseqüência da oxidação da solução de cloreto azul de nitrotetrazólio (NBT) na presença de nicotinamida adenina dinucleotídeo (NADH), avaliando-se por espectroscopia de absorção.

Jori e colaboradores ${ }^{43}$, em 2006, em um trabalho de revisão, concluíram que a PDT pode ser uma eficiente modalidade alternativa de tratamento para infecções microbianas localizadas, através da aplicação local de um FS, seguido por irradiação da área infectada. Possíveis campos clínicos para utilização desta terapia incluem o tratamento de ulceras crônicas, queimaduras infectadas, acne e uma variedade de infecções orais. Estes autores relataram, 
ainda, que um FS ideal deve possuir as seguintes características: ser positivamente carregado quando em pH fisiológico e possuir moderada lipofilicidade. Este tipo de FS pode, em baixas concentrações, reduzir de 4 a 5 logs de uma população microbiana após incubação e irradiação por curtos períodos de tempo.

\section{2 - Associação PDT e Peróxidos}

Garcez e colaboradores ${ }^{44}$, em 2002, utilizaram pela primeira vez, um fotossensibilizador associado a uma pasta a base de peróxido de uréia em cultura de $E$. faecalis. Os autores mostraram que a associação do fotossensibillizador azuleno com a pasta a base de peróxido resultou em maior redução bacteriana do que a observada quando da utilização do fotossensibilizador em solução aquosa. A análise por espectroscopia de absorção mostrou que a associação do azuleno com o peróxido não resultou em alterações significativas nas características do fotossensibilizador e aumentou sua eficiência na redução microbiana de $E$. faecalis.

Hayek e colaboradores ${ }^{45}$, em 2005, baseados no trabalho de Garcez, utilizaram a mesma pasta a base de peróxido e azuleno em peri-implantite provocada em cães. Em um período de 4 meses, a doença foi induzida em dezoito implantes previamente colocados na região dos primeiros pré-molares de cães labradores. Após a indução da inflamação peri-implantar, as amostras foram divididas em dois grupos. Um dos grupos foi submetido à curetagem cirúrgica por retalho muco-periostal. O outro grupo foi tratado por curetagem convencional com ultra-som e terapia fotodinâmica, utilizando a pasta e um 
laser de diodo de $50 \mathrm{~mW}$, emitindo em $\lambda=685 \mathrm{~nm}$. As coletas microbiológicas mostraram que a terapia fotodinâmica, assim como o tratamento cirúrgico, obteve significante redução microbiana para os seguintes microrganismos: Prevotela sp, Fusobacterium sp e Streptococcus beta-haemolyticus. Os autores concluíram que a PDT pode ser uma interessante terapia para a redução microbiana em peri-implantites, podendo ser uma alternativa ao tratamento cirúrgico.

Garcez e colaboradores $^{46}$, em 2006, investigaram a ação do FS azuleno associado a uma pasta de peróxido de uréia para a redução bacteriana em canais radiculares de dentes anteriores extraídos. Trinta canais radiculares de dentes anteriores extraídos foram contaminados com uma suspensão de $E$. faecalis por 24 h. $O$ grupo controle $(n=10)$ não recebeu nenhum tratamento. $O$ grupo tratamento convencional recebeu uma solução de $\mathrm{NaOCl}$ a $0,5 \%$ por 30 min e o grupo PDT recebeu a pasta de peróxido de uréia associada ao azuleno por 5 min, sendo irradiado com um laser de diodo $(\lambda=685 \mathrm{~nm})$ com uma energia de $1,8 \mathrm{~J}$ por $3 \mathrm{~min}$. A coleta microbiológica mostrou que a pasta fotossensibilizadora na ausência de radiação, ou a irradiação laser na ausência da pasta fotossensibilizadora, não promoveu nenhum efeito antimicrobiano. A solução de $\mathrm{NaOCl}$ por 30 min obteve redução de $93,25 \%$ e a PDT antimicrobiana reduziu $99,2 \%$ das bactérias no interior dos canais. Os autores concluíram que a PDT pode ser um interessante tratamento complementar à terapia endodôntica convencional.

McCullagh e Robertson ${ }^{47}$ investigaram os efeitos fotodinâmicos do AM na presença de $\mathrm{H}_{2} \mathrm{O}_{2}$ para a morte da cianobactéria Synechococcus leopoliensis. Os autores avaliaram a eficiência fotodinâmica através da 
deterioração da fluorescência do pigmento ficocianina, um pigmento responsável pela fotossíntese em cianobactérias, relacionando a destruição deste pigmento com a morte bacteriana. A toxicidade do composto $\mathrm{AM} / \mathrm{H}_{2} \mathrm{O}_{2}$ foi também avaliada e foi encontrada apenas uma morte bacteriana de $5 \%$ após 250 min, mostrando a baixa toxicidade da solução na ausência de luz. Após irradiação com luz halógena, a redução bacteriana foi de $80 \%$. Os autores concluíram que a irradiação do $S$. leopoliensis na presença de uma solução de AM e $\mathrm{H}_{2} \mathrm{O}_{2}$ resulta em morte bacteriana e na degradação do fotossensibilizador. Em uma atmosfera livre de $\mathrm{O}_{2}$, foi verificado um aumento na ação do composto AM/ H2O2. Baseados nesses achados, eles propõem que o processo envolve um mecanismo fotodinâmico do tipo I, onde um elétron é transferido do AM para o $\mathrm{H} 2 \mathrm{O} 2$, gerando espécies reativas de oxigênio, como radicais hidroxila e, mais provavelmente, radicais hidroperoxila. Os autores se basearam no trabalho de Gak e colaboradores de $1998^{48}$, que sugere três possíveis caminhos para esta reação: transferência de elétrons do FS excitado para o $\mathrm{H}_{2} \mathrm{O}_{2}$ com a formação de um radical cátion do $\mathrm{FS}$ e $\mathrm{OH}^{-}$, transferência de elétrons do $\mathrm{H}_{2} \mathrm{O}_{2}$ para a molécula do $\mathrm{FS}$ com a formação de um radical ânion do $\mathrm{FS}$ e $\mathrm{HO}_{2}{ }^{*}$ ou supressão do estado tripleto excitado pelo $\mathrm{H}_{2} \mathrm{O}_{2}$ sem a formação de nenhum subproduto. Os autores sugeriram ainda que a PDT antimicrobiana pode ter indicações para a destruição de biofilme formado por algas e cianobactérias em superfícies de pedra de edifícios e estátuas.

Em 2006, McCullagh e Robertson ${ }^{49}$ relataram o efeito fotodinâmico do AM na presença de $\mathrm{H}_{2} \mathrm{O}_{2}$ quando irradiado com luz visível, para a destruição da alga Chlorella vulgaris. Para determinar os mecanismos envolvidos neste processo, os experimentos foram realizados em condições de aerobiose e de 
anaerobiose. Os autores utilizaram o $\mathrm{AM}$ a $6 \mu \mathrm{M}$, associado ao $\mathrm{H}_{2} \mathrm{O}_{2}$ a $1 \mathrm{M}$, sob irradiação com uma lâmpada halógena de tungstênio de $500 \mathrm{~mW}$ por 240 min. Os resultados mostraram que na ausência de luz, a adição de $\mathrm{H}_{2} \mathrm{O}_{2}$ não produziu alterações significativas ao fotossensibilizador no período do experimento. Sob irradiação, a presença do $\mathrm{H}_{2} \mathrm{O}_{2}$ associado ao fotossensibilizador, aumentou a destruição da alga em aproximadamente 40\%, comparada à destruição deste organismo pelo FS sozinho. Quanto aos mecanismos envolvidos no processo fotodinâmico, McCullagh e Robertson sugeriram que em uma atmosfera aeróbica, há um predomínio da reação tipo II e que a presença de $\mathrm{H}_{2} \mathrm{O}_{2}$ produziu um aumento no tempo de vida do oxigênio singleto, levando a uma maior morte do microrganismo, ao mesmo tempo em que o oxigênio singleto atacaria $\circ \mathrm{H}_{2} \mathrm{O}_{2}$ produzindo radicais $\mathrm{OH}^{*}$, aumentando ainda mais a eficiência da PDT. Na atmosfera inerte livre de oxigênio, os autores não notaram diferenças significantes na morte da alga. Os resultados obtidos em atmosfera com $\mathrm{O}_{2}$ foram mantidos quando o oxigênio não estava presente. Segundo os autores, uma possível explicação para este fato é a ocorrência de reação tipo I e tipo II levando, portanto, a um aumento na morte do microrganismo.

\section{3 - Detecção de Espécies Reativas de Oxigênio}

A detecção de espécies reativas de oxigênio (ERO) é um desafio constante à pesquisa científica, pois requer o uso de ferramentas e métodos sensíveis e específicos para a investigação a fundo dos mecanismos envolvidos em processos biológicos. As ERO apresentam algumas 
características que as tornam difíceis de detectar, como seu curto tempo de vida e a variedade de antioxidantes e defesas naturais existentes in vivo capazes de reagir com estas espécies. Sondas fluorescentes são excelentes sensores para ERO, devido à sua alta sensibilidade, simplicidade de utilização e coleta de dados e resolução espacial para técnicas de microscopia de imagens. Os métodos de detecção utilizados atualmente são a Ressonância Spin Eletrônica (ESR), espectrofotometria, luminescência e fluorescência, sendo que os métodos diretos são mais precisos do que os métodos citados, já que possuem pouca estabilidade. As sondas ou seus produtos podem ser modificados pelo metabolismo celular e há pouca especificidade frente a agente redutores ou oxidantes. Entretanto, estes métodos são importantes ferramentas para identificação e quantificação de ERO. Diversos são os trabalhos na literatura, tanto in vitro como in vivo, demonstrando a detecção tanto indireta como direta de ERO.

LeBel e colaboradores ${ }^{50}$, em 1992 descreveram um método para detecção indireta de ERO em solução aquosa utilizando o composto diacetato de diclorofluoresceína (DCFH-DA). O DCFH-DA, na presença de ERO é convertido em diclorofluoresceína (DCF), uma molécula altamente fluorescente e facilmente detectável. Os autores detectaram a formação de radicais livres durante a clássica reação de Fenton, onde um íon metálico, neste caso o $\mathrm{Fe}^{++}$ é adicionado a uma solução de $\mathrm{H}_{2} \mathrm{O}_{2}$. Os autores alertam que como a reação de oxidação da DCFH e formação da DCF é mediada por diversas reações intermédiarias, este método deve ser utilizado com cuidado. Entretanto, eles concluíram que este é um atrativo método de detecção de ERO. 
Bourré e co-autores ${ }^{51}$ avaliaram em tecidos biopsiados a formação de ERO utilizando como sonda fluorescente o composto DCFH-DA. A detecção de radicais livres pelos compostos DCFH-DA/DCF foi primeiramente descrita por Keston e Brant em $1965^{52}$ e é baseado em dois passos: ativação do DCFH-DA por $\mathrm{NaOH}$, produzindo $\mathrm{DCFH}$, e oxidação deste composto para a formação de DCF. Os autores concluíram que este é um fácil, rápido e, principalmente, um método confiável para a detecção de ERO podendo ser um indicador da eficiência da PDT em tecidos biopsiados.

Wan e co-autores ${ }^{53}$ avaliaram através da fluorescência do DCF, o stress oxidativo produzido em culturas de células epiteliais por diferentes doses de radiação gama. Os autores concluíram que o DCFH é uma sonda capaz de detectar o stress oxidativo produzido por pequenas doses de radiação e que o aumento da fluorescência da DCF é diretamente proporcional ao aumento da dose de radiação a que as células foram expostas.

Gomes e colaboradores ${ }^{54}$, em 2005, revisaram a literatura sobre as sondas fluorescentes utilizadas para detecção de ERO. Os autores relatam a utilização de compostos de fluoresceína para a detecção do radical hidroxila tanto em meios biológicos como em meios não biológicos.

Bartosz ${ }^{55}$ revisou a literatura quanto ao uso de sondas espectroscópicas para a detecção de ERO. Dentre as diversas sondas citadas, pode-se destacar o uso do cloreto azul de nitrotetrazólio (NBT) para a detecção do radical superóxido e do composto DCFH-DA para a detecção de radicais livres, dentre eles, os grupos hidroxila, peroxinitrito, radicais peroxil, peróxido de hidrogênio e oxigênio singleto. 
Maisch e colaboradores ${ }^{56}$, em 2007, estudaram os processos oxidativos que ocorrem durante a morte bacteriana por PDT. Os autores detectaram diretamente, no interior da bactéria, a formação de oxigênio singleto através da sua luminescência em $\lambda=1270 \mathrm{~nm}$. A formação do ${ }^{1} \mathrm{O}_{2}$ foi avaliada em diferentes concentrações do fotossensibilizador, após diferentes tempos de pré-irradiação e na presença de concentrações crescentes de bactérias. Os resultados mostraram que o aumento da concentração de células levou a uma maior deterioração do sinal emitido pelo ${ }^{1} \mathrm{O}_{2}$. Os autores sugeriram que em concentrações baixas de bactérias por mililitro de solução, as ERO têm um tempo maior para sua difusão no interior das células e que este método mostrou a importância do suprimento de oxigênio para a eficiência da PDT antimicrobiana.

Koristov e colaboradores ${ }^{57}$, em 2007 , detectaram a quantidade de ERO no interior de duas linhagens de células tumorais humanas na presença de soro sanguíneo, através da oxidação da DCFH. Os autores determinaram a quantidade de ERO no interior das células e no meio utilizando medidas obtidas em um fluorímetro. 


\section{4 - MATERIAIS E MÉTODOS}

\section{1 - FOTOSSENSIBILIZADORES}

- Foram empregadas soluções do corante fenotiazínico azul de metileno (Sigma-Aldrich St. Louis, Missouri, EUA) sem purificação adicional em todos os ensaios efetuados, e um conjugado à base de clorina (gentilmente cedido pelo Prof. Michael R. Hamblin, Dep. de Dermatologia da Faculdade de Medicina da Universidade de Harvard EUA). Os Fs foram testados em diferentes concentrações, em solução com água destilada e em associação com solução de $\mathrm{H}_{2} \mathrm{O}_{2}$.

\section{2 - FONTE DE LUZ}

Os experimentos foram realizados empregando-se três diferentes fontes de luz:

Uma fonte de luz de amplo espectro, não coerente associada a um sistema de fibras intercambiáveis e a um filtro óptico, possibilitando a emissão de radiação em $630 \mathrm{~nm} \pm 30 \mathrm{~nm}$ e potência de $800 \mathrm{~mW}$ com a utilização da fibra (LumaCare LC 122M, Londres - Reino Unido).

Um laser de diodo de arseneto de gálio e alumínio de $50 \mathrm{~mW}$ de potência emitindo em 664 nm e em modo contínuo (Morgotron, São Carlos, Brasil)

Também foi utilizado um LED (light-emitting diode ou diodo emissor de Luz), com potência total de saída de $250 \mathrm{~mW}$. O pico da emissão deste equipamento é em $640 \mathrm{~nm}$, com uma banda de $\pm 30 \mathrm{~nm}$ (Protótipo LED 630, MMOptics, São Carlos, Brasil). 


\section{3 - ANÁLISE DA PRESENÇA DE OXIGÊNIO DISSOLVIDO DISPONÍVEL NA SOLUÇÃO DE FOTOSSENSIBILIZADOR}

Os solventes empregados, água destilada e peróxido de hidrogênio, foram acondicionados em um béquer na quantidade de $100 \mathrm{~mL}$, e foi realizada a medição de oxigênio dissolvido com medidor portátil de oxigênio dissolvido (Hanna Instruments, Londres, Reino Unido). As medidas foram feitas sob agitação magnética (150rpm) em temperatura ambiente. A sonda calibrada do medidor, com ajuste de altitude e salinidade, foi introduzida no béquer por 30s, para se obter uma leitura estável e os valores obtidos em ppm foram registrados. O experimento foi realizado no IPEN-CNEN/SP.

\section{4 - ANÁLISE DAS ALTERAÇÕES PROVOCADAS PELA ADIÇÃO DE $\mathrm{H}_{2} \mathrm{O}_{2}$ NA REDUÇÃO MIROBIANA POR TERAPIA FOTODINÂMICA}

\subsection{1 - REDUÇÃO BACTERIANA IN VITRO}

Culturas das bactérias Staphylococcus aureus (ATCC 27659), Pseudononas aeruginosas (ATCC 19660) e do fungo Candida albicans (51393) foram crescidas em $\mathrm{BHI}$ (brain heart infusion) a $37^{\circ} \mathrm{C}$ (em estufa) por 24 horas até que formassem uma cultura microbiana em fase de crescimento estacionário de aproximadamente $10^{9}$ microrganismos $/ \mathrm{mL}$. As culturas foram centrifugadas a 2.000 rpm por 10 minutos e ressuspensas em solução salina tamponada com fosfato (phosphate buffer saline - PBS). Um e meio $\mathrm{mL}$ da solução contendo um dos microrganismos (Staphylococcus aureus, Pseudomonas aeruginosa e Candida albicans) foi dividida em sete grupos e 
colocada em uma placa de 96 poços. Os grupos 1, 2 e 3 receberam, respectivamente, por 30 minutos: nenhum tratamento, $60 \mu \mathrm{M}$ de $\mathrm{AM}$ e $1 \mathrm{M}$ de $\mathrm{H}_{2} \mathrm{O}_{2}$ na ausência de luz.

Os grupos 4, 5, 6 e 7 receberam respectivamente: $60 \mu \mathrm{M}$ de $\mathrm{AM}, 60 \mu \mathrm{M}$ de $\mathrm{AM}$ associado a $10 \mathrm{mM}$ de $\mathrm{H}_{2} \mathrm{O}_{2}, 60 \mu \mathrm{M}$ de $\mathrm{AM}$ associado a $100 \mathrm{mM}$ de $\mathrm{H}_{2} \mathrm{O}_{2}$ e $60 \mu \mathrm{M}$ de $\mathrm{AM}$ associado a $1 \mathrm{M}$ de $\mathrm{H}_{2} \mathrm{O}_{2}$. Os grupos $4,5,6$ e 7 , após os 10 minutos de pré-irradiação, receberam $40 \mathrm{~J} / \mathrm{cm}^{2}$ de irradiação.

Todas as irradiações foram realizadas com a lâmpada halógena e foram executadas de forma que o espalhamento de luz em cada um dos poços irradiados na placa não interferisse com o grupo seguinte do experimento. Após o experimento $100 \mu \mathrm{L}$ de cada grupo foram transferidos para uma placa de 96 poços, submetidos à diluição seriada em PBS até a diluição de $10^{-6} \mathrm{e}$ incubados em placas de Petri com ágar $\mathrm{BHI}$ por 24 horas em estufa a $37^{\circ} \mathrm{C}$ para contagem de unidades formadoras de colônias (ufc) de acordo com a metodologia proposta por Jeff et $\left.a\right|^{58}$. Este método foi utilizado em cada um dos microrganismos citados e os experimentos realizados em triplicata.

O mesmo experimento, com os mesmos parâmetros e seguindo a mesma metodologia foi utilizada com o FS conjugado a base de clorina. Também estes experimentos foram realizados em triplicata. Os experimentos foram realizados no Wellman Center for Photomedicine - Harvard Medical School. 


\section{5 - ANÁLISE DOS MECANISMOS FOTOFíSICOS E FOTOQUÍMICOS ENVOLVIDOS NA PDT EM PRESENÇA DE PERÓXIDO DE HIDROGÊNIO}

\subsection{1 - DETECÇÃO INDIRETA DE ERO PELA DEGRADAÇÃO DO RNO}

Para a detecção de oxigênio singleto as seguintes substâncias químicas foram utilizadas em uma cubeta de quartzo com volume total de $3 \mathrm{~mL}$ e com 1 cm de caminho óptico: N,N dimetil-4-notrosoanilina (RNO) e L-histidina (Aldrich, Milwaukee, EUA) utilizadas sem purificações adicionais.

Na cubeta foram adicionados $15 \mathrm{mM}$ do L-histidine, $5 \mu \mathrm{M}$ do FS e água destilada q.s.p. Uma medida inicial da absorção foi realizada para comparação. Foi então adicionado à cubeta, $13,3 \mu \mathrm{M}$ do RNO e uma nova medida da absorção foi realizada, analisando-se a absorção no comprimento de onda de $440 \mathrm{~nm}$. A amostra foi irradiada em intervalos de 1 minuto com fonte halógena. Para garantir uma irradiação uniforme, visto que, a fonte de luz não irradiava toda a superfície da cubeta, um agitador magnético foi inserido no interior da mesma, mantendo o liquido no interior da amostra em constante movimentação, durante todo o tempo de irradiação.

A avaliação da produção de oxigênio singleto pelo AM e pelo conjugado a base de clorina sob irradiação por fonte de luz branca de $500 \mathrm{~mW}$, foi realizada através da análise da atenuação da densidade óptica em 440nm, como conseqüência da degradação da solução de RNO na presença de Lhistidina, utilizando-se um espectrofotômetro (8453 UV-Visible System, Agilent Technologies. Palo Alto, CA, EUA). O mesmo método foi repetido substituindose $1 \mathrm{~mL}$ da solução aquosa por $1 \mathrm{~mL}$ de $\mathrm{H}_{2} \mathrm{O}_{2}$ a $1 \mathrm{M}$. 
A detecção indireta de oxigênio singleto foi realizada utilizando-se os FS AM e o conjugado a base de clorina, em água destilada e em solução de $\mathrm{H}_{2} \mathrm{O}_{2}$. Os experimentos foram realizados no Wellman Center for Photomedicine Harvard Medical School.

\subsection{2 - DETECÇÃO DIRETA DE OXIGÊNIO SINGLETO POR FOSFORESCÊNCIA EM $\lambda=1270 \mathrm{~nm}$}

A análise da produção de oxigênio singleto foi realiza em solução dos FS a $30 \mu \mathrm{M}$ preparada em $\mathrm{D}_{2} \mathrm{O}$ e em solução dos $\mathrm{FS}(30 \mu \mathrm{M})$ associados ao $\mathrm{H}_{2} \mathrm{O}_{2}$ a $1 \mathrm{M}$ preparada também em $\mathrm{D}_{2} \mathrm{O}$.

Os espectros de absorção das soluções foram obtidos em cubetas de quartzo com caminho óptico de $1 \mathrm{~cm}$ em espectrômetro interfaceado com computador (Multispec-1501, Shimadzu, Japão).

As varreduras foram efetuadas de $\lambda=280 \mathrm{~nm}$ a $\lambda=800 \mathrm{~nm}$. Espectros de fluorescência foram obtidos em cubetas de quartzo com $1 \mathrm{~cm}$ de caminho óptico em fluorímetro (Spex 1681, Fluorolog, EUA) com excitação em $\lambda=532 \mathrm{~nm}$ e registros obtidos de $\lambda=600 \mathrm{~nm}$ a $\lambda=800 \mathrm{~nm}$.

Através da análise dos espectros de absorção e fluorescência, foi feita a correção da concentração de FS.

A emissão no infravermelho do oxigênio singleto foi obtida após excitação da amostra com laser de Nd:YAG (Surelite III, Continuum, Santa Clara, EUA) operando em $\lambda=532 \mathrm{~nm}$ com energia de pulso de $30 \mathrm{~mJ}$ e com largura de pulso de 10ns, excitando a amostra em um fluorímetro (Edinburgh Analytical Instruments, Livingston, Reino Unido) conectado a uma 
fotomultiplicadora para infravermelho (R5509 Hamamatsu Co., Bridgewater, EUA).

O comprimento de onda de emissão foi selecionado utilizando-se filtro de sílica e monocromador. A emissão do oxigênio singleto transiente foi obtida através do acúmulo do sinal obtido após 20 pulsos de irradiação. Os resultados foram analisados utilizando-se um software apropriado. O experimento foi realizado no Laboratório de Processos Fotoinduzidos e Interfaces IQ/USP.

\subsection{3 - DETECÇÃO INDIRETA DE SUPERÓXIDO ATRAVÉS DA OXIDAÇÃO DO NBT}

Para a detecção do ânion superóxido $\left(\mathrm{O}_{2}^{-}\right)$, as seguintes substâncias químicas foram utilizadas em uma cubeta de quartzo com volume total de $3 \mathrm{~mL}$ e com $1 \mathrm{~cm}$ de caminho óptico: cloreto azul de nitrotetrazolium (NBT) e dinucleotídeo de nicotinamida e adenina (NADH) (Aldrich, Milwaukee, EUA) utilizadas sem purificações adicionais.

Na cubeta foram adicionados $80 \mu \mathrm{M}$ da NADH, $10 \mathrm{mM}$ de NBT e água destilada q.s.p. Uma medida inicial da absorção foi realizada para comparação.

Foi então adicionado à cubeta, $10 \mu \mathrm{M}$ do $\mathrm{FS}$ e uma nova medida da absorção foi realizada, analisando-se a absorção no comprimento de onda de 580nm. A amostra foi irradiada em intervalos de 1 minuto e analisada como descrito anteriormente. Para garantir uma irradiação uniforme, visto que a fonte de luz não irradiava toda a superfície da cubeta, um agitador magnético foi inserido no interior da mesma, mantendo o liquido no interior da amostra em constante movimentação, durante todo o tempo de irradiação.

A avaliação da produção de superóxido pelo $\mathrm{AM}$ e pelo conjugado a base de clorina sob irradiação por fonte de luz branca de $500 \mathrm{~mW}$, foi realizada 
através da análise do aumento da densidade óptica em 580nm, como conseqüência da oxidação da solução de NBT na presença de NADH, utilizando-se um espectrofotômetro (8453 UV-Visible System, Agilent Technologies. Palo Alto, CA, EUA). O mesmo método foi repetido substituindose $1 \mathrm{~mL}$ da solução aquosa por $1 \mathrm{~mL}$ de $\mathrm{H}_{2} \mathrm{O}_{2}$ a $1 \mathrm{M}$.

Também neste experimento, a detecção de superóxido foi realizada utilizando-se os FS AM e o conjugado a base de clorina, em água destilada e em solução de $\mathrm{H}_{2} \mathrm{O}_{2}$. Os experimentos foram realizados no Wellman Center for Photomedicine - Harvard Medical School.

\subsection{4 - DETECÇÃO INDIRETA DE ERO PELA OXIDAÇÃO DO DCFH}

Para a detecção de ERO, as seguintes substâncias químicas foram utilizadas em uma cubeta de quartzo com volume total de $3 \mathrm{~mL}$ e caminho óptico de $1 \mathrm{~cm}$ : diacetato de diclorofluoresceina (DCFH-DA), ácido sulfúrico e hidróxido de sódio (Aldrich, Milwaukee, EUA) utilizadas sem purificações adicionais.

Na cubeta foram adicionados $20 \mu \mathrm{L}$ da DCFH-DA (100 nM) e $10 \mu \mathrm{L}$ de ácido sulfúrico por 20 minutos para a remoção do radical diacetato. Após os 20 minutos foi adicionado $10 \mu \mathrm{L}$ de hidróxido de sódio para a neutralização do ácido.

Para a tomada das medidas de formação dos radicais livres foi acrescido à diclorofluoresceina previamente preparada, o FS e água destilada.

A amostra foi irradiada com um laser de diodo de $50 \mathrm{~mW}$, emitindo no comprimento de onda de $664 \mathrm{~nm}$ por 10 segundos. 
A formação dos ERO foi mensurada pela fluorescência da DCF em $520 \mathrm{~nm}$ após excitação da amostra em 490nm. De modo sucinto, o aparecimento da fluorescência é explicado pela oxidação do composto DCFH pelas espécies reativas de oxigênio e formação da molécula altamente fluorescente DCF.

O mesmo método foi repetido substituindo-se $600 \mu \mathrm{L}$ da solução aquosa por $1 \mu \mathrm{L}$ de peróxido de hidrogênio a $1 \mathrm{M}$.

Também neste experimento, a deteç̧ão ERO foi realizada utilizando-se os FS Azul de metileno e o conjugado a base de clorina, em água destilada e em solução de $\mathrm{H}_{2} \mathrm{O}_{2}$. O experimento foi realizado no Laboratório de Processos Fotoinduzidos e Interfaces IQ/USP.

\subsection{5 - DETECÇÃO INDIRETA DE ERO PELA OXIDAÇÃO DO DCFH NO INTERIOR DE CÉLULAS EUCARIÓTICAS}

Uma suspensão do microrganismo C. albicans foi previamente incubada em solução contendo $\mathrm{AM}$ a $60 \mu \mathrm{M}$ por $10 \mathrm{~min}$. Após a remoção do fotossensibilizador por centrifugação a 3000rpm por 6 minutos as células foram incubadas em uma solução de $10 \mu \mathrm{M}$ de diacetado de diclorofluoresceina (DCFH-DA) por 15 minutos e novamente centrifugadas como descrito anteriormente para a remoção do DCFH-DA não absorvido pelo microrganismo.

As células foram, então, irradiadas em intervalos de 1 minuto, por um laser de diodo com $40 \mathrm{~mW}(\lambda=664 \mathrm{~nm})$ em doses sucessivas de $4,8 \mathrm{~J} / \mathrm{cm}^{2}$ e avaliadas por microscopia de fluorescência. Foi realizada a captação de uma 
imagem a cada minuto para a detecção da formação de espécies reativas de oxigênio no interior do microrganismo. As imagens das células foram obtidas utilizando-se um microscópio de fluorescência, onde uma alíquota de $100 \mu \mathrm{L}$ da solução, disposta em uma lâmina de vidro e coberta por uma lamínula do mesmo material, foi excitada em $500 \mathrm{~nm}$. A fluorescência do DCF foi captada utilizando-se um filtro de corte de $\lambda<500 \mathrm{~nm}$, em função do tempo de irradiação. As células foram irradiadas em duas condições distintas: na presença ou ausência de $\mathrm{H}_{2} \mathrm{O}_{2}$.

As imagens obtidas foram analisadas pelo software image $\mathrm{J}$ (National Institute of Health, USA) e Adobe Photoshop CS3 versão para Machintosh (Adobe, USA). Em cada imagem foram selecionadas 20 células, sendo que, estes conjuntos de células foram avaliados quanto a intensidade de fluorescência através da análise de seu histograma. Os dados resultantes foram analisados graficamente em função do tempo de irradiação. $O$ experimento foi realizado no Laboratório de Cristalografia, IFUSP. 


\section{6 - ANÁLISE dOS MECANISMOS FOTOQUímiCOS E BIOLÓgICOS ENVOLVIDOS NA PDT EM PRESENÇA DE PERÓXIDO DE HIDROGÊNIO}

\subsection{1 - CAPTAÇÃO DO FS PELA BACTÉRIA SOB AÇÃO DE $\mathrm{H}_{2} \mathrm{O}_{2}$}

Culturas de E. coli (HB101) na concentração de $10^{9}$ bactérias por $\mathrm{mL}$ foram centrifugadas e suspensas em solução PBS.

Amostras da bactéria em PBS foram distribuídas aleatoriamente em 3 grupos:

Grupo FS : $1 \mathrm{~mL}$ da suspensão bacteriana recebeu $1 \mathrm{~mL}$ do FS a $60 \mu \mathrm{M}$ por 10 minuto. A suspensão foi centrifugada a 2000 rpms por 10 minutos, o sobrenadante foi removido e analisado por espectroscopia de absorção óptica para quantificação do FS não absorvido pela bactéria, através da análise da concentração do mesmo na solução.

Grupo $\mathrm{FS}+\mathrm{H}_{2} \mathrm{O}_{2}: 1 \mathrm{~mL}$ da suspensão bacteriana recebeu uma associação do FS a $60 \mu \mathrm{M}$ em $1 \mathrm{~mL}$ de $\mathrm{H}_{2} \mathrm{O}_{2}$ a $1 \mathrm{M}$ por 10 minuto. A suspensão foi centrifugada a 2000 rpms por 10 minutos e o sobrenadante foi removido para quantificação do FS não absorvido pela bactéria.

Grupo $\mathrm{H}_{2} \mathrm{O}_{2}+\mathrm{FS}$ : $1 \mathrm{~mL}$ da suspensão bacteriana recebeu $1 \mathrm{~mL}$ de $\mathrm{H}_{2} \mathrm{O}_{2}$ a $1 \mathrm{M}$ por 10 minutos. A suspensão foi centrifugada a 2000 rpms por 10 minutos e o peróxido foi removido. As bactérias foram, então ressuspensas em PBS e foi adicionado $60 \mu \mathrm{M}$ de FS por outros 10 minutos. A solução foi novamente centrifugada a 2000 rpms por 10 minutos e o sobrenadante foi removido para quantificação do FS não absorvido pela bactéria. 
O experimento foi realizado com o fotossensibilizador AM e a análise foi realizada através da comparação dos espectros de absorção entre os respectivos grupos, nos laboratórios do IPEN-CNEN/SP.

O mesmo experimento foi realizado com o conjugado de clorina, entretanto, utilizando-se uma cultura de C. albicans ao invés de E. Coli e a análise da captação do FS pelo microrganismo foi realizada por microscopia de fluorescência. As análises das imagens foram realizadas como descrito no item 4.5.5 para análise da formação de ERO, isto é, pela intensidade da fluorescência do FS no interior das células. Este experimento foi realizado no Laboratório cristalografia IFUSP.

\subsection{2 - MECANISMOS BIOQUÍMICOS DA MORTE BACTERIANA EM PRESENÇA DE PERÓXIDO}

Diferentes seqüências da associação do peróxido com o FS foram testadas em cultura de E. coli (HB101).

Culturas da bactéria foram crescidas em BHI (brain heart infusion) a $37^{\circ} \mathrm{C}$ (em estufa) por 24 horas até que atingissem a fase de crescimento estacionário de aproximadamente $10^{9}$ microrganismos $/ \mathrm{mL}$. As culturas foram centrifugadas a $2.000 \mathrm{rpm}$ por 10 minutos e ressuspensas em PBS. Foram, então selecionados 3 grupos experimentais:

Grupo 1: $100 \mu \mathrm{L}$ da solução contendo a bactéria foi colocada em uma placa de 96 poços e recebeu por 10 minutos $60 \mu \mathrm{M}$ de FS associado a $1 \mathrm{M}$ de $\mathrm{H}_{2} \mathrm{O}_{2}$. A amostra recebeu após o período de pré-irradiação, $40 \mathrm{~J} / \mathrm{cm}^{2}$ de irradiação com o LED. 
Grupo 2: $100 \mu \mathrm{L}$ da solução contendo a bactéria foi colocada em placa de 96 poços e recebeu por 10 minutos $1 \mathrm{M}$ de $\mathrm{H}_{2} \mathrm{O}_{2}$. Após os 10 minutos, a suspensão foi centrifugada a 2000 rpms por 10 minutos e o peróxido foi removido. As bactérias foram, então, ressuspensas em PBS e foi adicionado $60 \mu \mathrm{M}$ de FS por outros 10 minutos. A amostra recebeu após o período de pré-irradiação, 40 $\mathrm{J} / \mathrm{cm}^{2}$ de irradiação com o LED.

Grupo 3: $100 \mu \mathrm{L}$ da solução contendo a bactéria foi colocada em uma placa de 96 poços e recebeu por 10 minutos $60 \mu \mathrm{M}$ do FS. Após os 10 minutos, a suspensão foi centrifugada a 2000 rpms por 10 minutos e o FS foi removido. As bactérias foram, então, ressuspensas em PBS e receberam $40 \mathrm{~J} / \mathrm{cm}^{2}$ de irradiação com o LED. Após a irradiação, foi adicionado à suspensão $1 \mathrm{M}$ de $\mathrm{H}_{2} \mathrm{O}_{2}$ por outros 10 minutos.

Todas as irradiações foram realizadas de forma que o espalhamento de luz em cada um dos poços irradiados não interferisse com o grupo seguinte do experimento. Após o experimento $100 \mu \mathrm{L}$ de cada grupo foram transferidos para uma placa de 96 poços, submetidos à diluição seriada em PBS até a diluição de $10^{-6}$ e incubados em placas de petri com ágar BHI por 24h para contagem de ufc. Os experimentos foram realizados em triplicata, nos laboratórios do IPEN-CNEN/SP.

\subsubsection{1 - ANÁLISE ESTATÍSTICA}

Os dados resultantes destes experimentos foram analisados estatisticamente através do teste $t$ de Student utilizando-se o software Microsoft Excel (Microsoft, EUA). 


\section{5 - RESULTADOS}

\section{1 - ANÁLISE DA PRESENÇA DE OXIGÊNIO DISSOLVIDO DISPONÍVEL NA SOLUÇÃO DE FOTOSSENSIBILIZADOR}

A análise dos solventes utilizados revelou que há uma diferença na disponibilidade de $\mathrm{O}_{2}$ entre a água deionizada e $\mathrm{H}_{2} \mathrm{O}_{2}$. Os valores obtidos estão descritos na tabela abaixo:

\begin{tabular}{|c|c|}
\hline SOLVENTE & OXIGÊNIO DISSOLVIDO (ppm) \\
\hline Água destilada & 7,48 \\
\hline Peróxido de hidrogênio & 9,74 \\
\hline
\end{tabular}

Tabela 1 - Média da quantidade de $\mathrm{O}_{2}$ dissolvido nos solventes analisados. Observa-se que na presença de $\mathrm{H}_{2} \mathrm{O}_{2}$ há um aumento aproximado de $20 \%$ na disponibilidade de $\mathrm{O}_{2}$. 


\section{2 - ANÁLISE DAS ALTERAÇÕES PROVOCADAS PELA ADIÇÃO DE $\mathrm{H}_{2} \mathrm{O}_{2}$ NA REDUÇÃO MICROBIANA POR TERAPIA FOTODINÂMICA}

\subsection{1-Redução Microbiana in vitro - Toxicidade no escuro.}

Todos os microrganismos testados, sofreram redução quando em contato com o $\mathrm{FS}(60 \mu \mathrm{M})$ ou com o $\mathrm{H}_{2} \mathrm{O}_{2}(1 \mathrm{M})$ sem a ativação dos mesmo com luz, mostrando que estes compostos apresentam certa toxicidade. Os gráficos 1 e 2 assim como as tabelas 2 e 3, mostram a redução microbiana obtida para cada um dos FS e pelo peróxido de hidrogênio sobre os microrganismos testados.

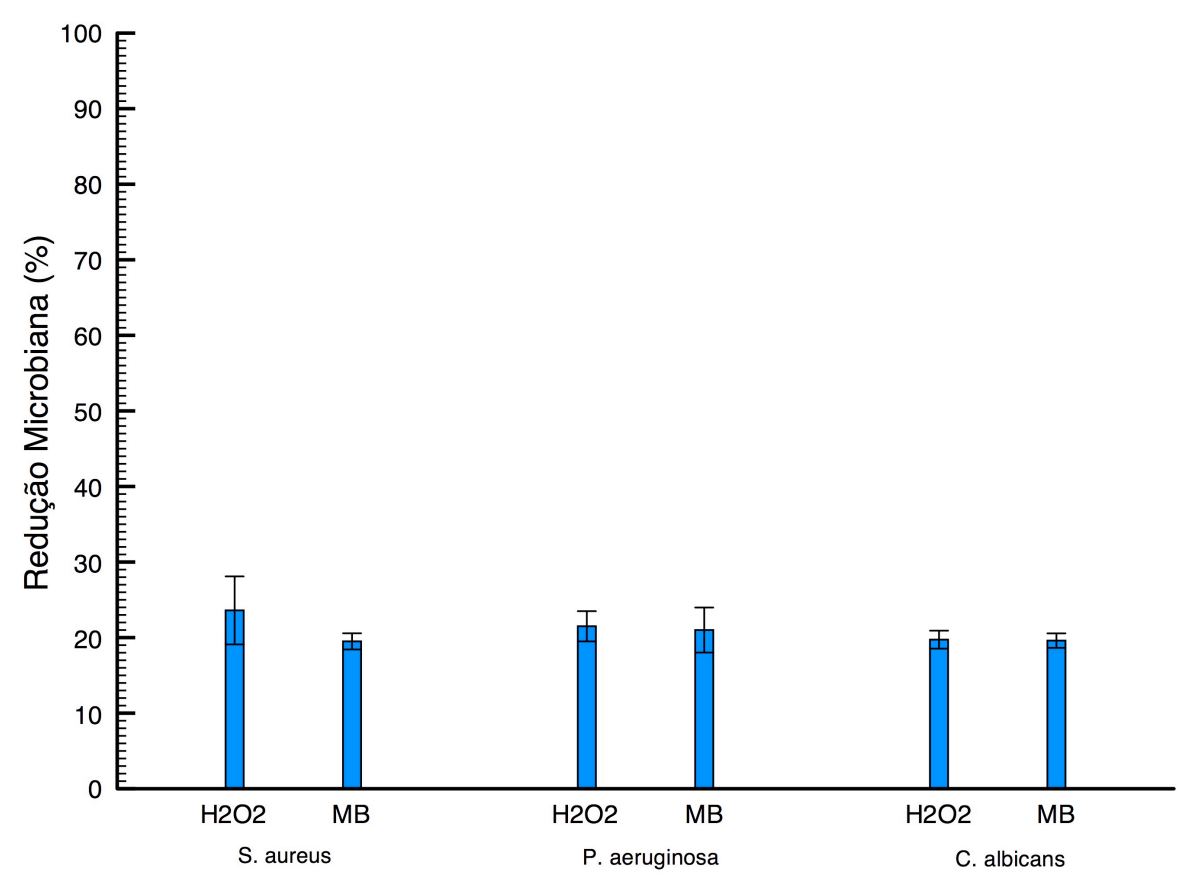

Gráfico 1: Média e desvio padrão da redução microbiana resultante da toxicidade intrínseca de cada fotossensibilizador em bactérias Gram+ (S. aureus), Gram- ( $P$. aeruginosa) e fungos (C. albicans). 


\begin{tabular}{|l|c|c|c|c|}
\hline & Redução AM & Desvio padrão & Redução $\mathrm{H}_{2} \mathrm{O}_{2}$ & Desvio padrão \\
\hline S. aureus & 19,5 & 1,07 & 26,6 & 4,5 \\
\hline P. aeruginosa & 17 & 2,98 & 21,5 & 2 \\
\hline C. albicans & 19,6 & 0,96 & 19,73 & 1,19 \\
\hline
\end{tabular}

Tabela 2: Média e desvio padrão da redução microbiana resultante da toxicidade intrínseca do fotossensibilizador

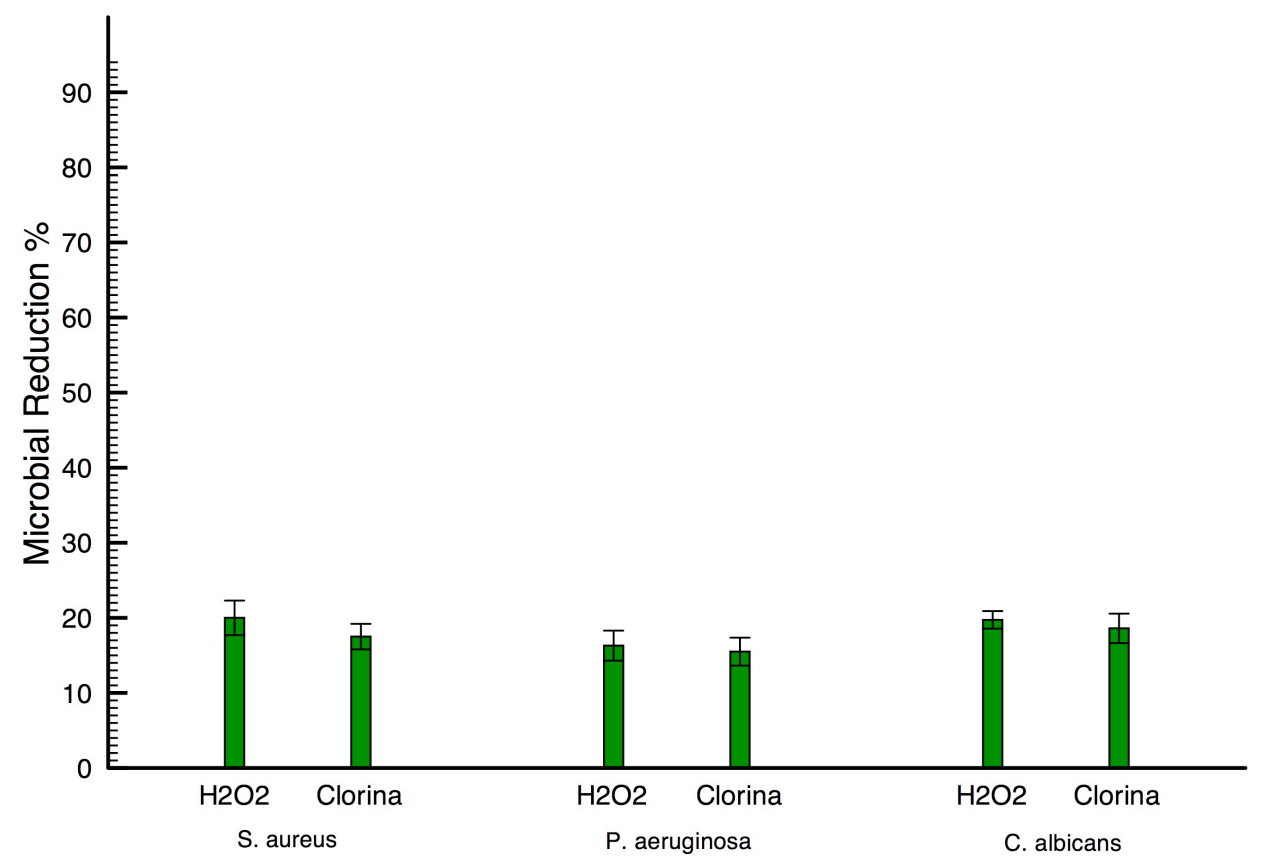

Gráfico 2: Média e desvio padrão da redução microbiana resultante da toxicidade intrínseca do fotossensibilizador e do peróxido de hidrogênio em fotossensibilizador em bactérias Gram+ (S. aureus), Gram- ( $P$. aeruginosa) e fungos (C. albicans). 


\begin{tabular}{|l|c|c|c|c|}
\hline & Redução Clorina & Desvio padrão & Reduç $\mathrm{H}_{2} \mathrm{O}_{2}$ & Desvio padrão \\
\hline S. aureus & 17,5 & 1,7 & 20 & 2,3 \\
\hline P. aeruginosa & 15,5 & 1,86 & 16,3 & 2 \\
\hline C. albicans & 18,6 & 1,96 & 17,73 & 1,17 \\
\hline
\end{tabular}

Tabela 3: Média e desvio padrão da redução microbiana resultante da toxicidade intrínseca do fotossensibilizador e do peróxido de hidrogênio.

\subsection{2 - Redução Microbiana in vitro}

Todos os microrganismos testados, em maior ou menor grau, perderam viabilidade celular após terem sido submetidos ao efeito fotodinâmico. Os gráficos 3, 4 e 5 mostram, respectivamente, a redução microbiana em bactérias Gram+, Gram- e fungos quando da utilização de AM e os gráficos 6, 7 e 8 a redução obtida com o conjugado a base de Clorina em solução aquosa ou em solução de peróxido, com diferentes concentrações de $\mathrm{H}_{2} \mathrm{O}_{2}$. Ambos os FS foram irradiados com a lâmpada LumaCare (LC 122M, Londres - Reino Unido), com uma dose de $40 \mathrm{~J} / \mathrm{cm}^{2}$. Os resultados mostram que o efeito fotodinâmico foi mais efetivo na presença de peróxido. Alem disso, concentrações maiores de peróxido, produziu um aumento na redução microbiana.

Entretanto em nenhum dos microrganismos, mesmo quando o fotossensibilizador foi associado ao peróxido, foi alcançado $100 \%$ de redução, caracterizando estes parâmetros, portanto, como subletais. 


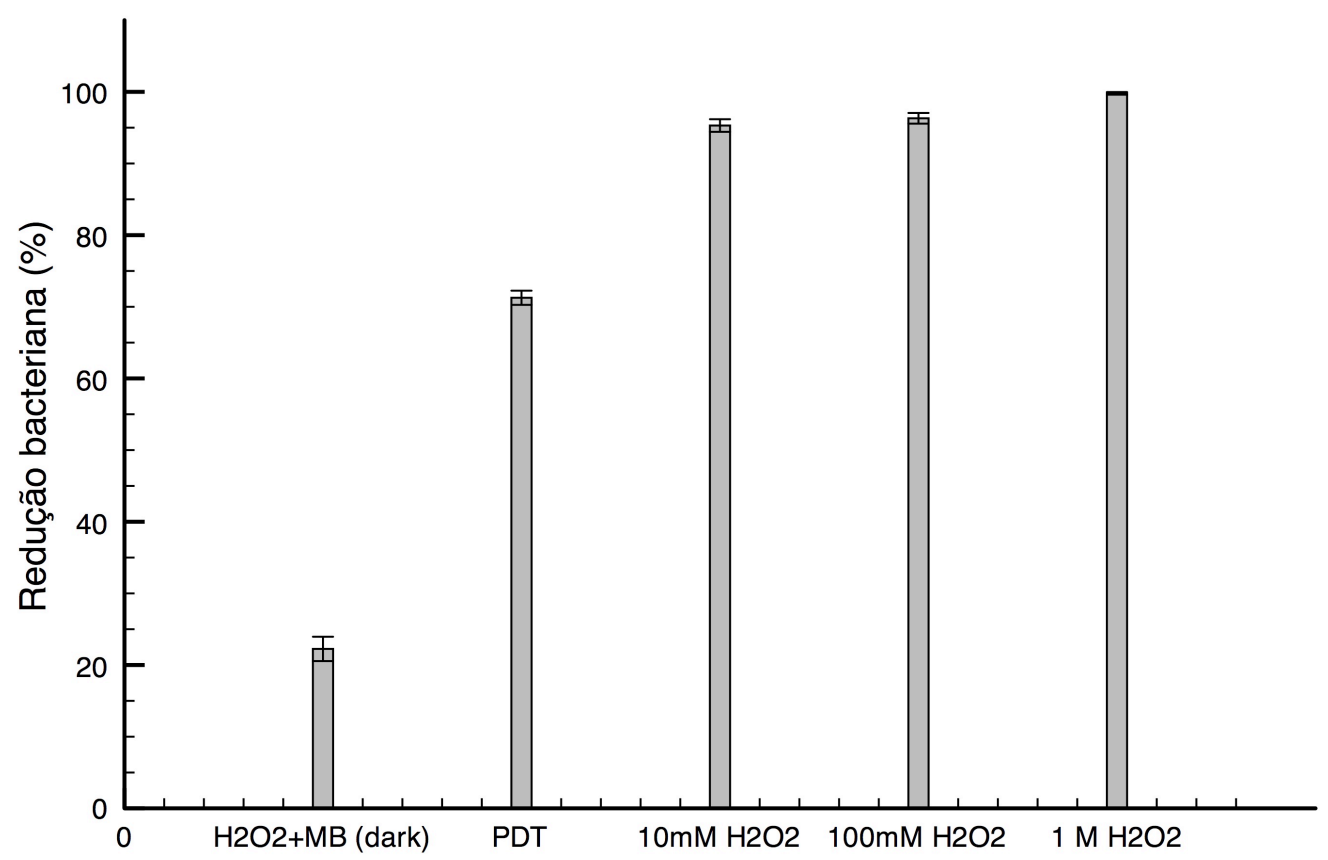

Gráfico 3: Média e desvio padrão da redução microbiana de $S$. aureus (bactéria Gram+) resultante da toxicidade do AM em solução de $\mathrm{H}_{2} \mathrm{O}_{2}$ e da PDT na ausência e na presença de três concentrações de $\mathrm{H}_{2} \mathrm{O}_{2}$. 


\begin{tabular}{|l|l|l|l|l|l|}
\hline & $\mathrm{H}_{2} \mathrm{O}_{2}+\mathrm{AM}$ & PDT & PDT + & PDT + & PDT + \\
& & & $\mathrm{mM}$ & $100 \mathrm{mM}$ & $1 \mathrm{M}$ \\
\hline Redução (\%) & 22,25 & 71,26 & 95,3 & 96,31 & 99,79 \\
\hline Desvio padrão & 1,7 & 0,99 & 0,88 & 0,745 & 0,185 \\
\hline
\end{tabular}

Tabela 4: Média e desvio padrão de redução microbiana de $S$. aureus resultante da toxicidade do AM em solução de $\mathrm{H}_{2} \mathrm{O}_{2}$ e da PDT na ausência e na presença de três concentrações de $\mathrm{H}_{2} \mathrm{O}_{2}$.

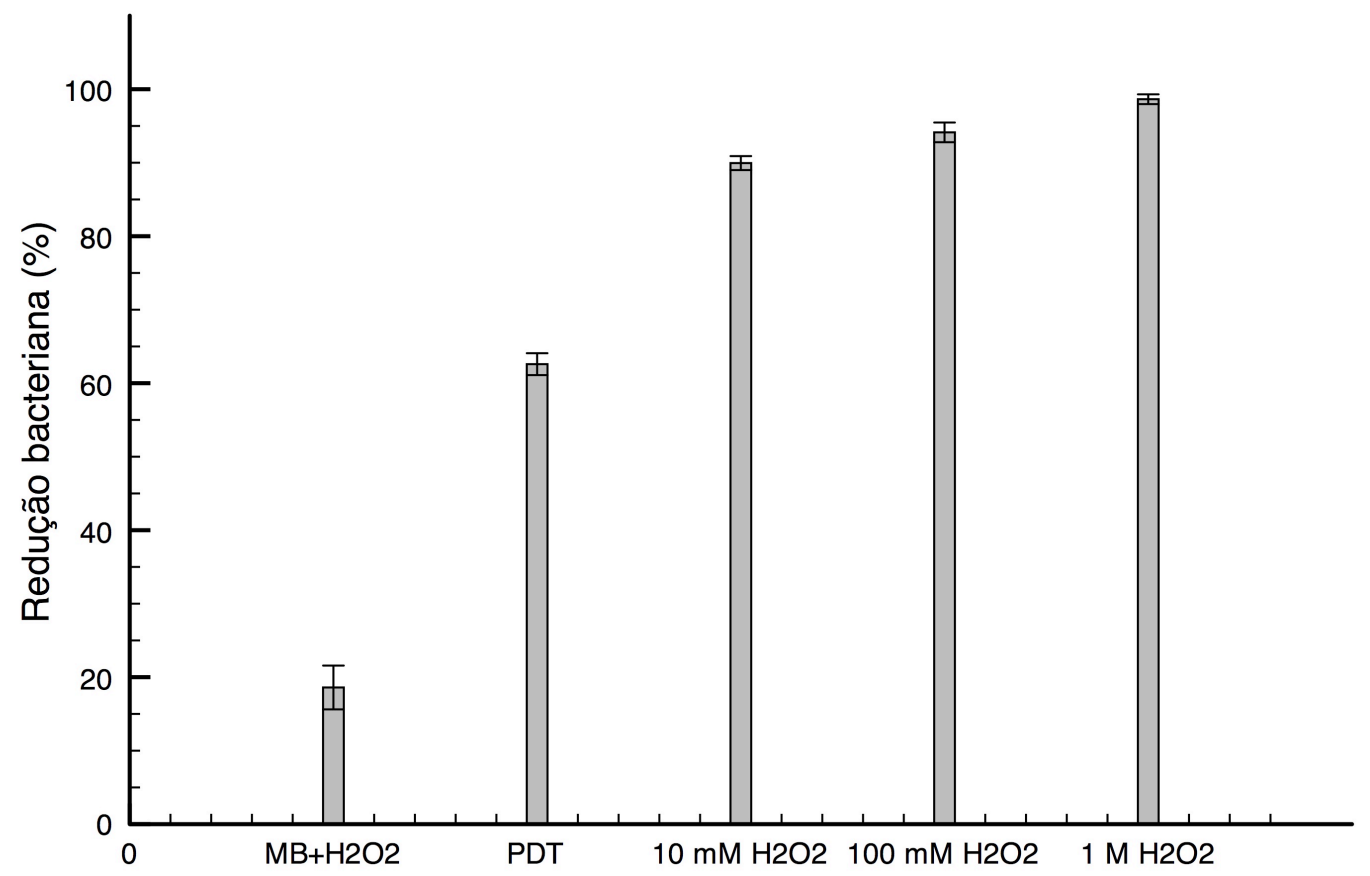

Gráfico 4: Média e desvio padrão da redução microbiana de $P$. aeruginosa (bactéria Gram-) resultante da toxicidade do AM em solução de $\mathrm{H}_{2} \mathrm{O}_{2}$ e da PDT na ausência e na presença de três concentrações de $\mathrm{H}_{2} \mathrm{O}_{2}$. 


\begin{tabular}{|l|l|l|l|l|l|}
\hline & $\mathrm{H}_{2} \mathrm{O}_{2}+\mathrm{AM}$ & PDT & PDT + & PDT + & PDT + \\
& & & $\mathrm{mM}$ & $100 \mathrm{mM}$ & $1 \mathrm{M}$ \\
\hline Redução (\%) & 20,5 & 62,59 & 89,95 & 94,13 & 98,64 \\
\hline Desvio padrão & 2,98 & 1,49 & 0,95 & 1,34 & 0,665 \\
\hline
\end{tabular}

Tabela 5: Média e desvio padrão da redução microbiana de $P$. aeruginosa resultante da toxicidade do AM em solução de $\mathrm{H}_{2} \mathrm{O}_{2}$ e da PDT na ausência e na presença de três concentrações de $\mathrm{H}_{2} \mathrm{O}_{2}$.

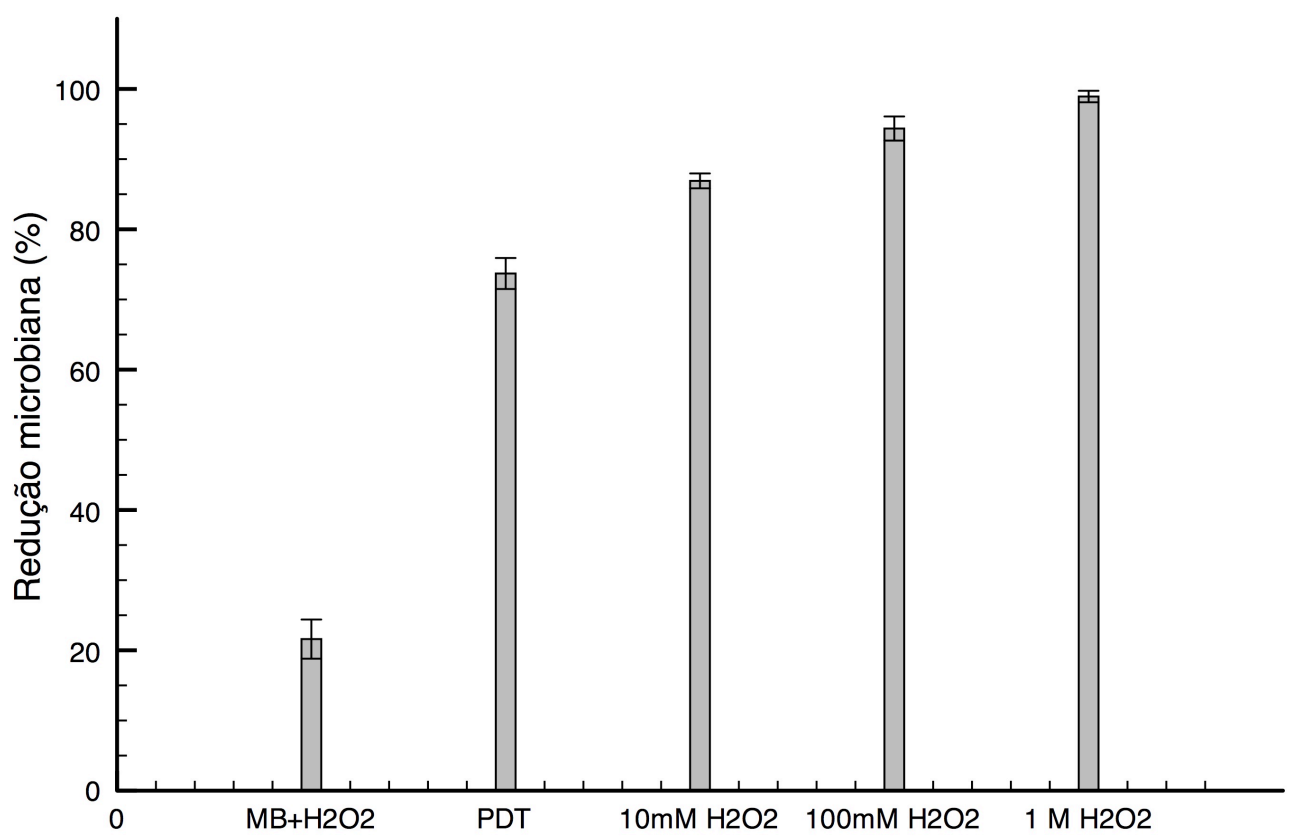

Gráfico 5: Média e desvio padrão da redução microbiana de C.albicans (fungo) resultante da toxicidade do AM em solução de $\mathrm{H}_{2} \mathrm{O}_{2}$ e da PDT na ausência e na presença de três concentrações de $\mathrm{H}_{2} \mathrm{O}_{2}$. 


\begin{tabular}{|l|l|l|l|l|l|}
\hline & $\mathrm{H}_{2} \mathrm{O}_{2}+\mathrm{AM}$ & PDT & PDT + & PDT + & PDT + \\
& & & $\mathrm{mM}$ & $100 \mathrm{mM}$ & $1 \mathrm{M}$ \\
\hline Redução (\%) & 21,6 & 73,7 & 86,9 & 94,36 & 98,92 \\
\hline Desvio padrão & 2,79 & 2,21 & 1,06 & 1,72 & 0,823 \\
\hline
\end{tabular}

Tabela 6: Média e desvio padrão da redução microbiana de C.albicans resultante da toxicidade do AM em solução de $\mathrm{H}_{2} \mathrm{O}_{2}$ e da PDT na ausência e na presença de três concentrações de $\mathrm{H}_{2} \mathrm{O}_{2}$.

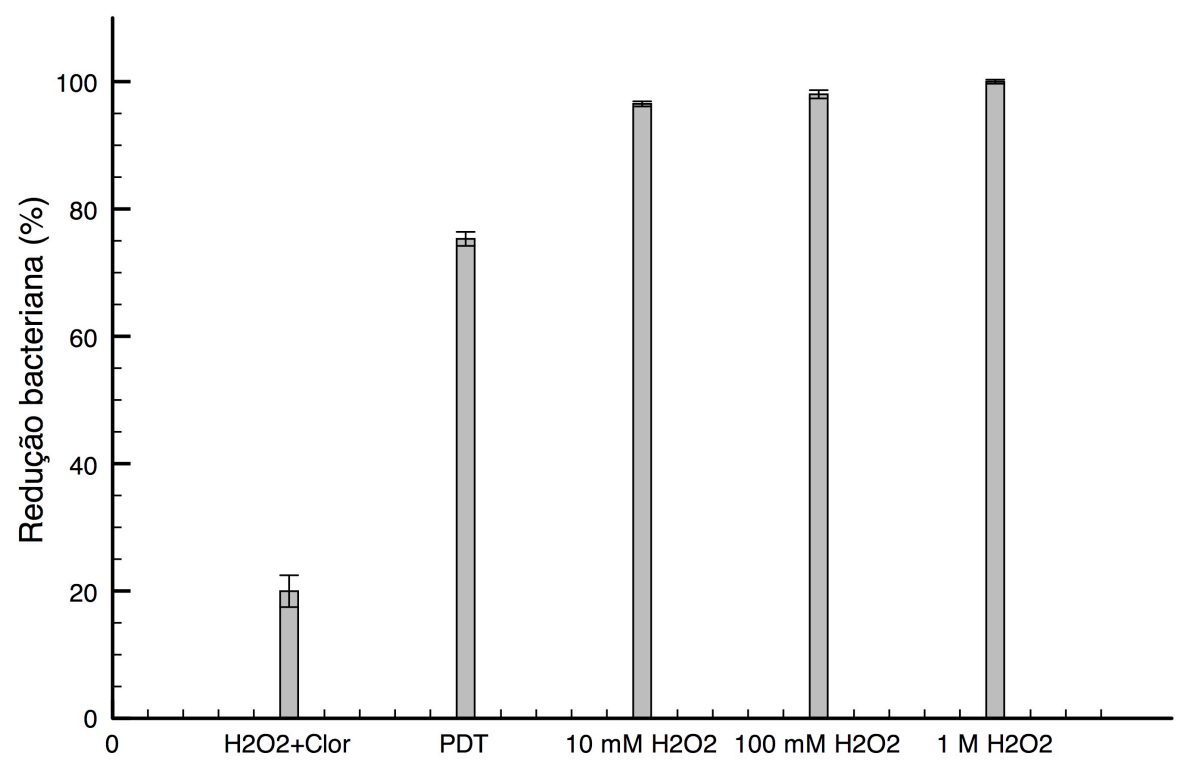

Gráfico 6: Média e desvio padrão da redução microbiana de S. aureus (bactéria Gram+) resultante da toxicidade do conjugado a base de clorina em solução de $\mathrm{H}_{2} \mathrm{O}_{2}$ e da PDT na ausência e na presença de três concentrações de $\mathrm{H}_{2} \mathrm{O}_{2}$. 


\begin{tabular}{|l|l|l|l|l|l|}
\hline & $\mathrm{H}_{2} \mathrm{O}_{2}+$ Clorina & PDT & PDT + & PDT + & PDT + \\
& & $10 \mathrm{mM}$ & $100 \mathrm{mM}$ & $1 \mathrm{M}$ \\
\hline Redução (\%) & 19,97 & 75,3 & 96,5 & 98,01 & 99,995 \\
\hline Desvio padrão & 2,5 & 1,1 & 0,4 & 0,65 & 0,32 \\
\hline
\end{tabular}

Tabela 7: Média e desvio padrão da redução microbiana de $S$. aureus resultante da toxicidade do conjugado a base de clorina em solução de $\mathrm{H}_{2} \mathrm{O}_{2} \mathrm{e}$ da PDT na ausência e na presença de três concentrações de $\mathrm{H}_{2} \mathrm{O}_{2}$.

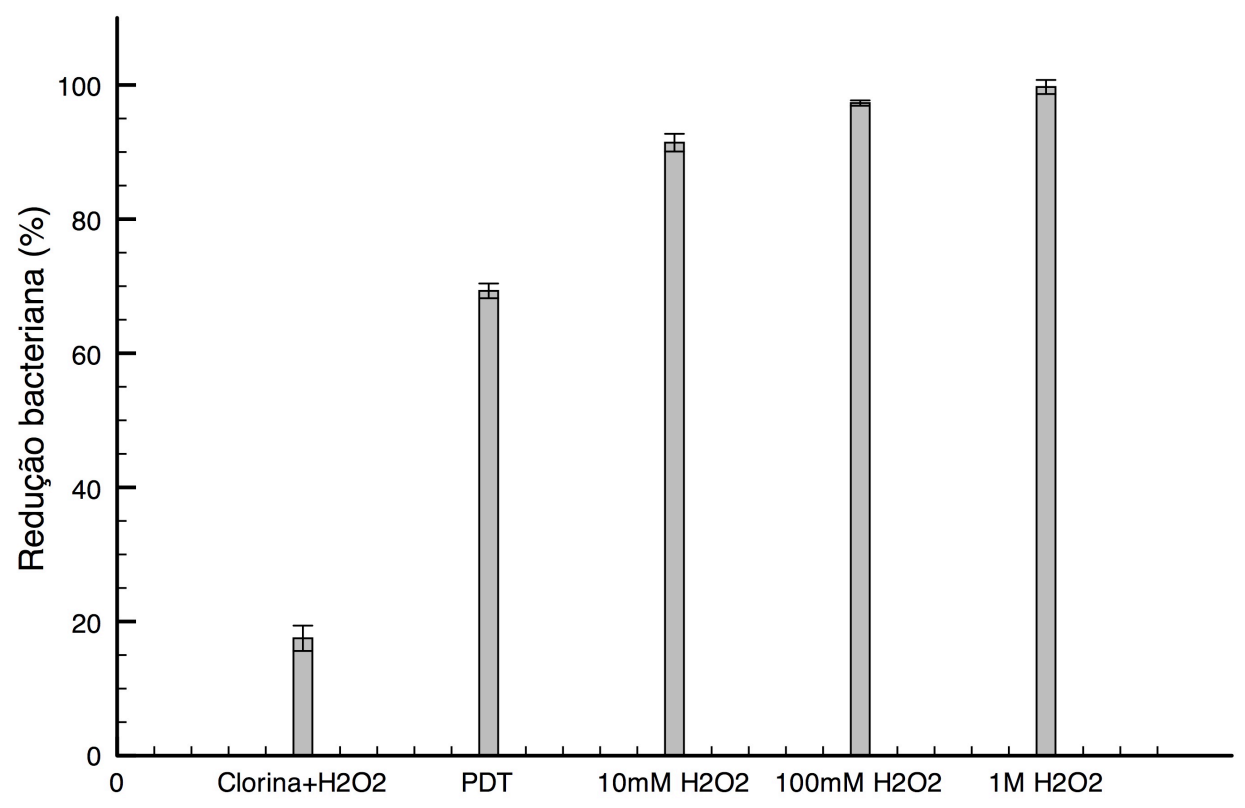

Gráfico 7: Média e desvio padrão da redução microbiana de $P$. aeruginosa (bactéria Gram-) resultante da toxicidade do conjugado a base de clorina em solução de $\mathrm{H}_{2} \mathrm{O}_{2}$ e da PDT na ausência e na presença de três concentrações de $\mathrm{H}_{2} \mathrm{O}_{2}$. 


\begin{tabular}{|l|l|l|l|l|l|}
\hline & $\mathrm{H}_{2} \mathrm{O}_{2}+$ Clorina & PDT & PDT + & PDT + & PDT + \\
$10 \mathrm{mM}$ & $100 \mathrm{mM}$ & $1 \mathrm{M}$ \\
\hline Redução (\%) & 17,5 & 69,3 & 91,4 & 97,3 & 99,7 \\
\hline Desvio padrão & 1,89 & 1,3 & 1,302 & 0,4 & 1,05 \\
\hline
\end{tabular}

Tabela 8: Média e desvio padrão da redução microbiana de $P$. aeruginosa resultante da toxicidade do conjugado a base de clorina em solução de $\mathrm{H}_{2} \mathrm{O}_{2} \mathrm{e}$ da PDT na ausência e na presença de três concentrações de $\mathrm{H}_{2} \mathrm{O}_{2}$.

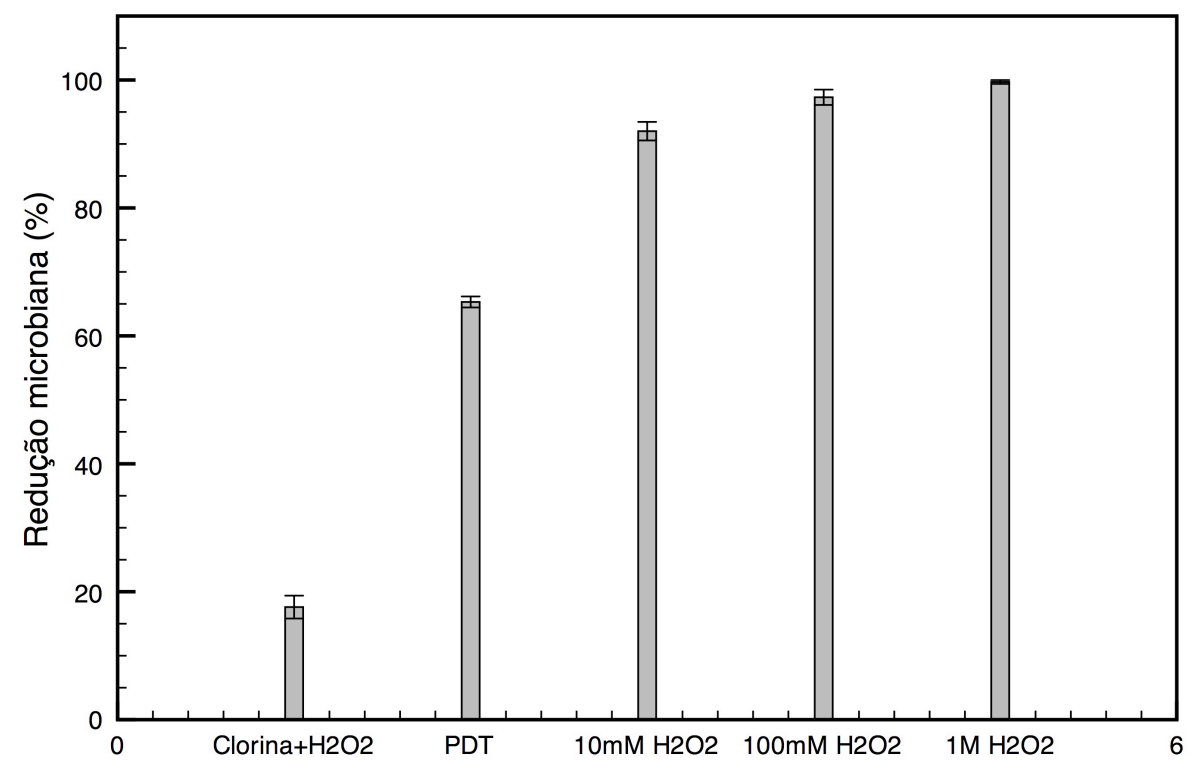

Gráfico 8: Média e desvio padrão da redução microbiana de C. albicans (fungo) resultante da toxicidade do conjugado a base de clorina em solução de $\mathrm{H}_{2} \mathrm{O}_{2} \mathrm{e}$ da PDT na ausência e na presença de três concentrações de $\mathrm{H}_{2} \mathrm{O}_{2}$. 


\begin{tabular}{|l|l|l|l|l|l|}
\hline & $\mathrm{H}_{2} \mathrm{O}_{2}+$ Clorina & PDT & PDT + & PDT + & PDT + \\
& & $10 \mathrm{mM}$ & $100 \mathrm{mM}$ & $1 \mathrm{M}$ \\
\hline Redução (\%) & 17,6 & 65,327 & 92 & 97,3 & 99,69 \\
\hline Desvio padrão & 1,79 & 0,86 & 1,45 & 1,2 & 0,322 \\
\hline
\end{tabular}

Tabela 9: Média e desvio padrão da redução microbiana de C.albicans resultante da toxicidade do conjugado a base de clorina em solução de $\mathrm{H}_{2} \mathrm{O}_{2} \mathrm{e}$ da PDT na ausência e na presença de três concentrações de $\mathrm{H}_{2} \mathrm{O}_{2}$.

\section{3 - ANÁLISE DOS MECANISMOS FOTO-FíSICOS E FOTO-QUÍMICOS ENVOLVIDOS NA PDT NA PRESENÇA DE PERÓXIDO DE HIDROGÊNIO}

\subsection{1 - Detecção indireta de Oxigênio singleto por degradação do RNO}

Os gráficos 9 e 10 representam, respectivamente, a dinâmica de formação de oxigênio singleto, após a irradiação dos FS em solução aquosa ou em solução de peróxido, detectados indiretamente através da degradação do composto RNO na presença de L-histidina. A diminuição da absorção do RNO medida em 440nm indica a presença do oxigênio singleto, pois na presença desta ERO a L-histidina reage como oxigênio singleto formando uma substância intermediária que degrada o RNO levando a sua detecção evdenciada pela diminuição da intensidade em $440 \mathrm{~nm}$.

É possível observar que para ambos os $\mathrm{FS}$, a adição de $\mathrm{H}_{2} \mathrm{O}_{2}$ diminuiu a formação de ${ }^{1} \mathrm{O}_{2}$, já que a curva representando o $\mathrm{FS}$ em solução de peróxido decai lentamente durante o tempo de irradiação. 


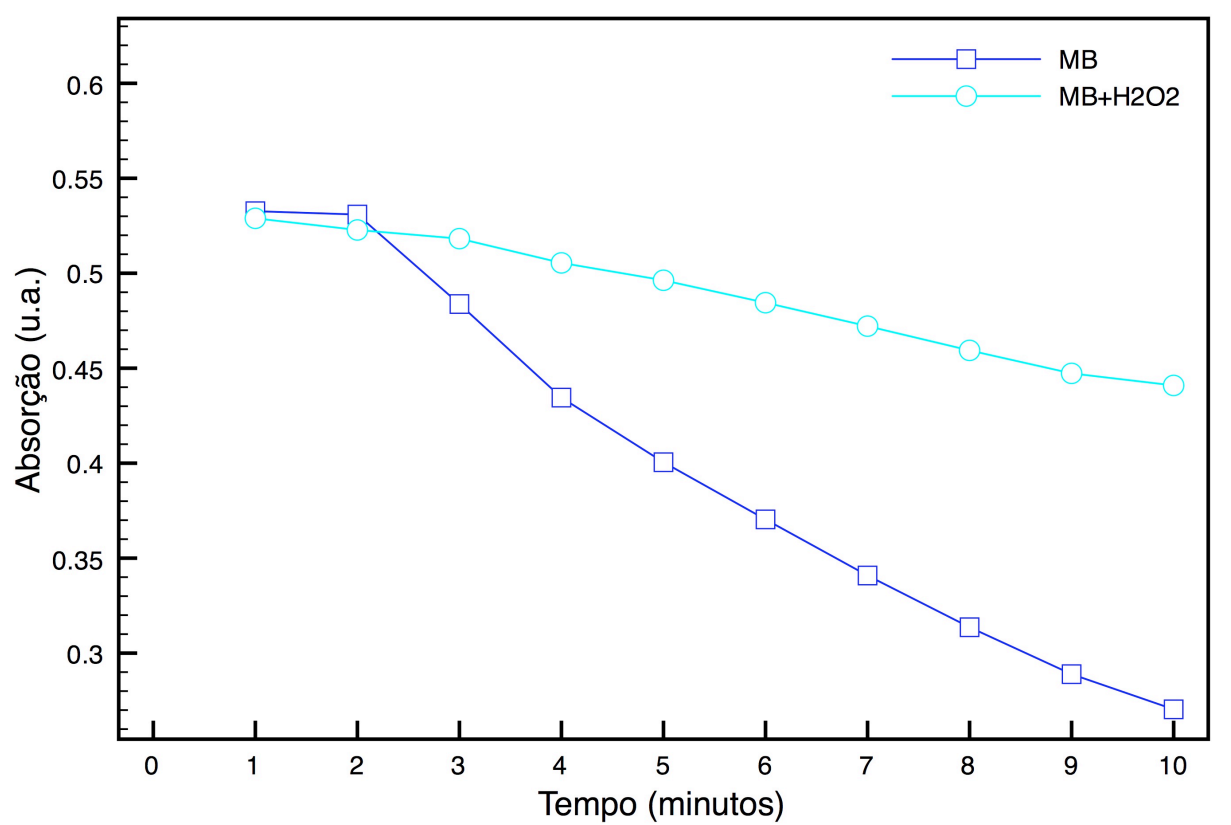

Gráfico 9: Formação do oxigênio singleto após irradiação de solução de AM e AM associado ao $\mathrm{H}_{2} \mathrm{O}_{2}$.

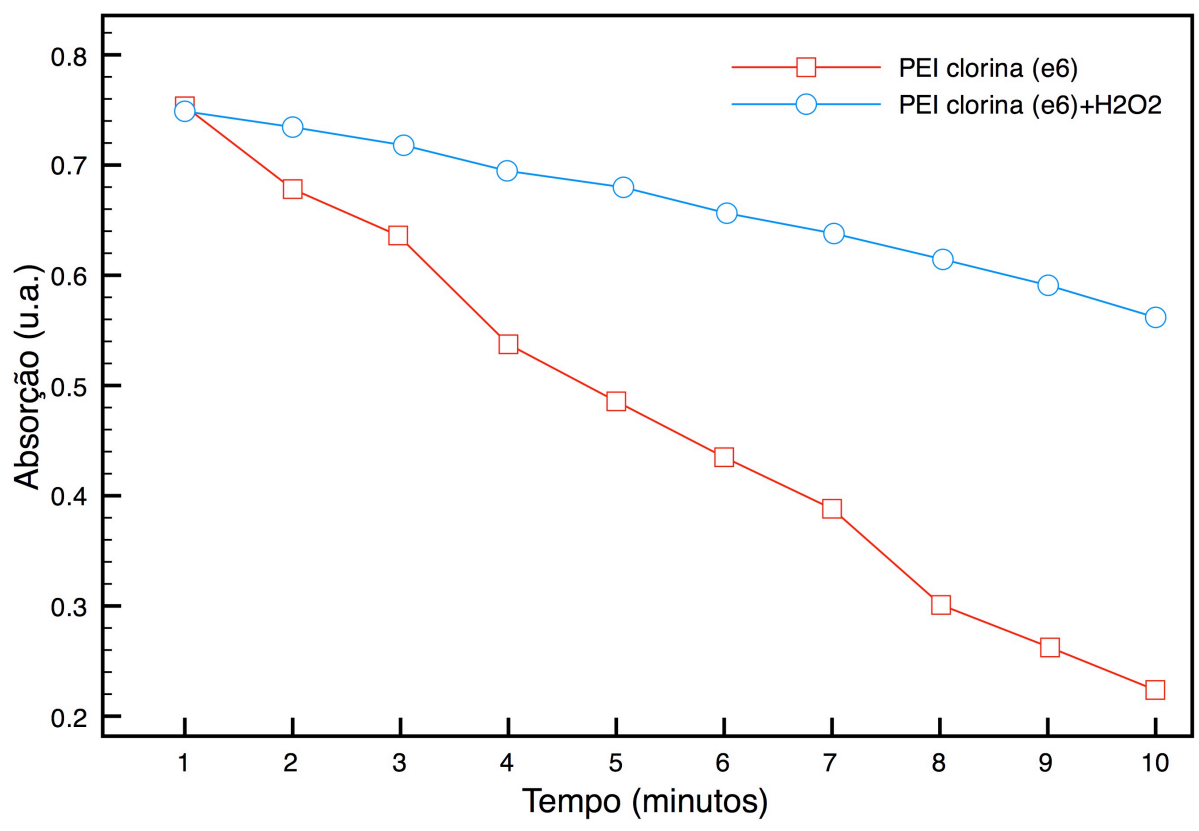

Gráfico 10: Formação do oxigênio singleto após irradiação da solução contendo o conjugado a base de clorina e deste fotossensibilizador associado ao $\mathrm{H}_{2} \mathrm{O}_{2}$. 
5.3.2 - Detecção direta do oxigênio singleto por fosforescência em $\lambda=1270$ $\mathrm{nm}$

O gráfico 11 mostra a formação do oxigênio singleto pelo efeito fotodinâmico do conjugado a base de clorina quando excitados por um laser de Neodímio pulsado no segundo harmônico, emitindo em $532 \mathrm{~nm}$, detectados diretamente através da emissão fosforescente do oxigênio singleto em 1270nm. Observa-se que o sinal de fosforescência do conjugado a base de clorina na presença de peróxido tem sua intensidade diminuída em relação ao sinal do FS esta em solução aquosa, indicando uma diminuição na formação de do ${ }^{1} \mathrm{O}_{2}$.

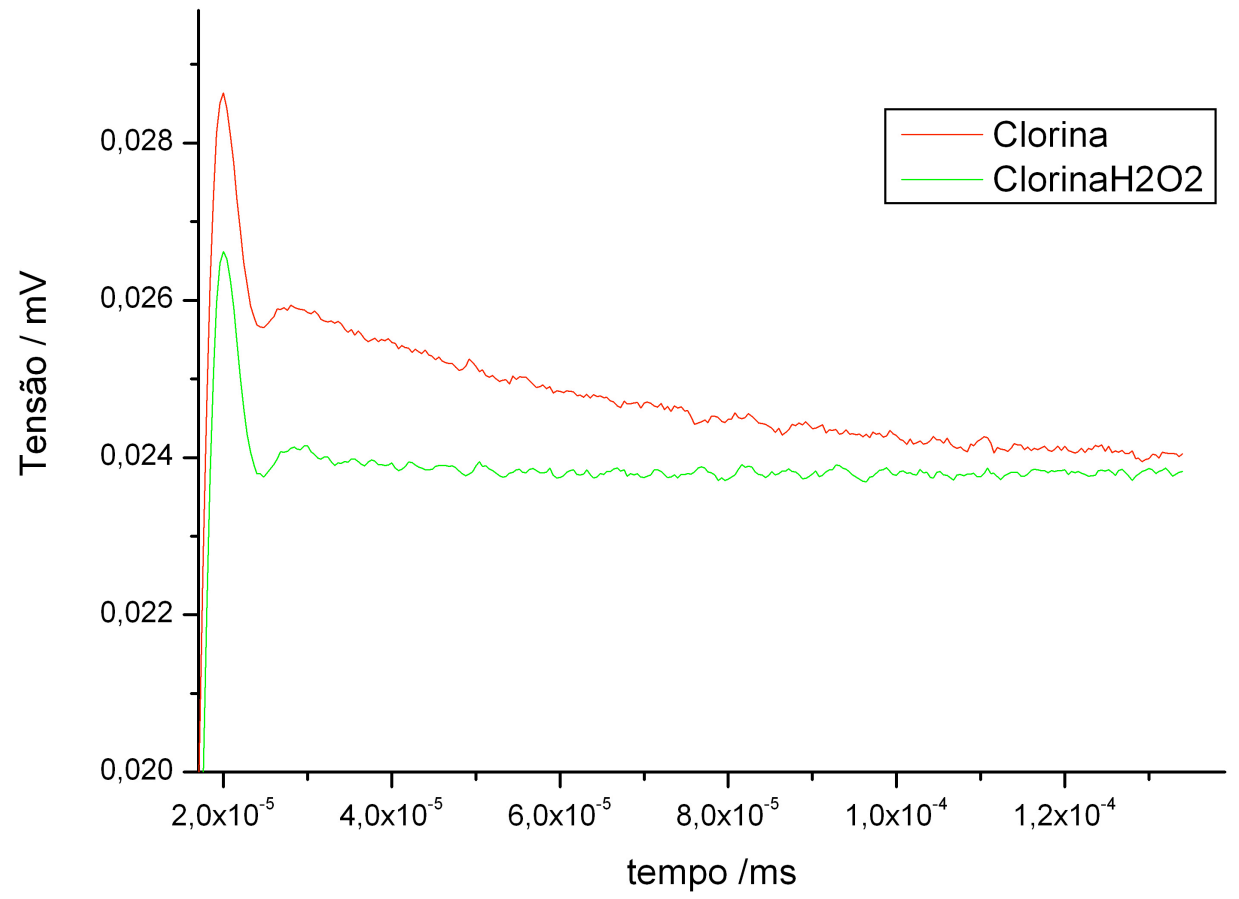

Gráfico 11: Detecção de oxigênio singleto pelo efeito fotodinâmico do conjugado a base de clorina na presença e na ausência de $\mathrm{H}_{2} \mathrm{O}_{2}$. 


\subsection{3 - Detecção de ERO por oxidação do NBT}

Os Gráficos 12 e 13 representam, respectivamente, a dinâmica de formação de superóxido, pela irradiação do azul de metileno e do conjugado a base de clorina, detectados indiretamente através da oxidação do composto NBT na presença de NADH. A oxidação do NBT produz um aumento da densidade óptica deste composto em 580nm indicando a presença de espécies reativas de oxigênio, em especial o superóxido. Nota-se que a adição de $\mathrm{H}_{2} \mathrm{O}_{2}$ mantém quase constante a intensidade de absorção para ambos os FS.

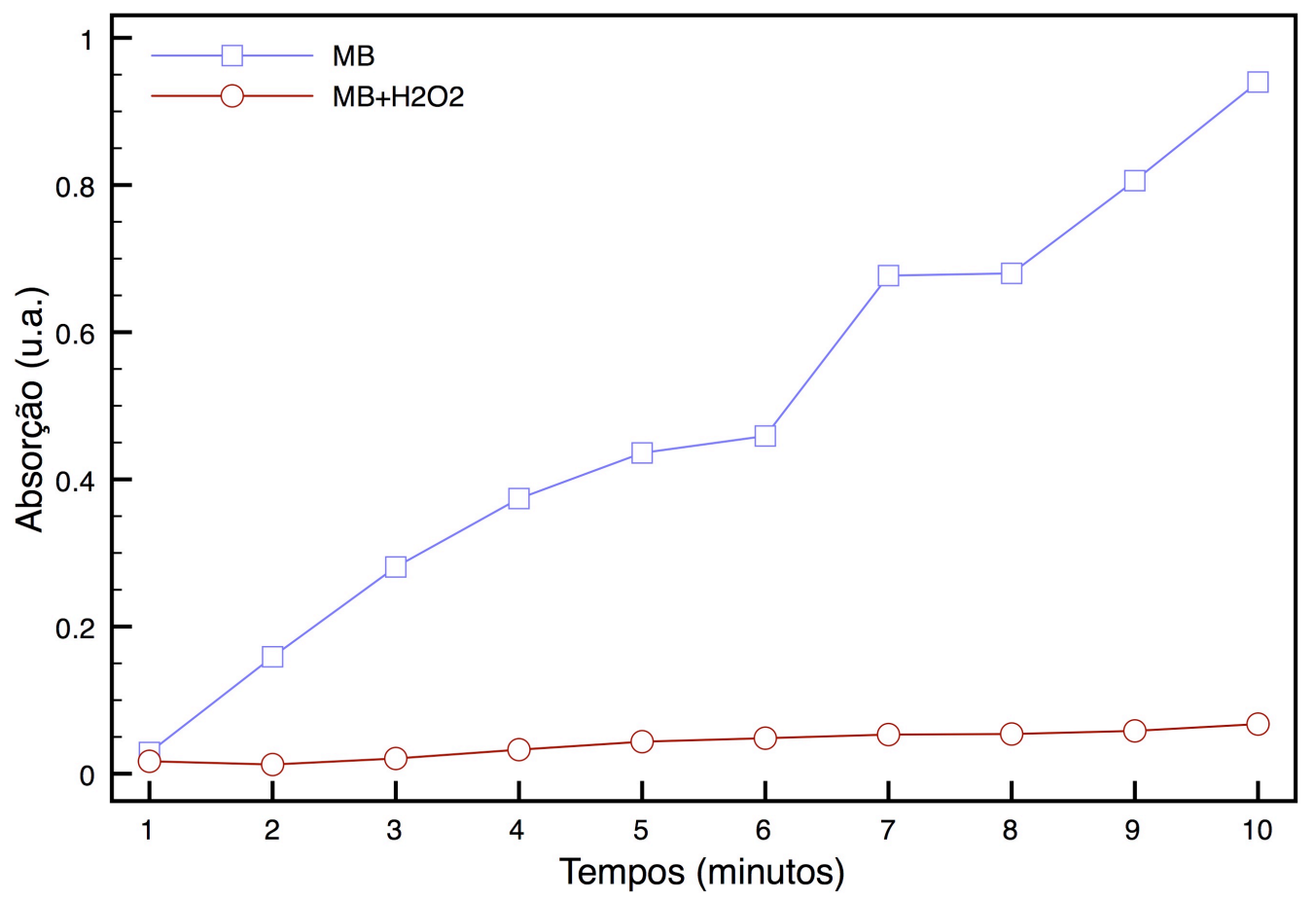

Gráfico 12: Formação de superóxido pela irradiação do AM e deste fotossensibilizador associado ao $\mathrm{H}_{2} \mathrm{O}_{2}$. 


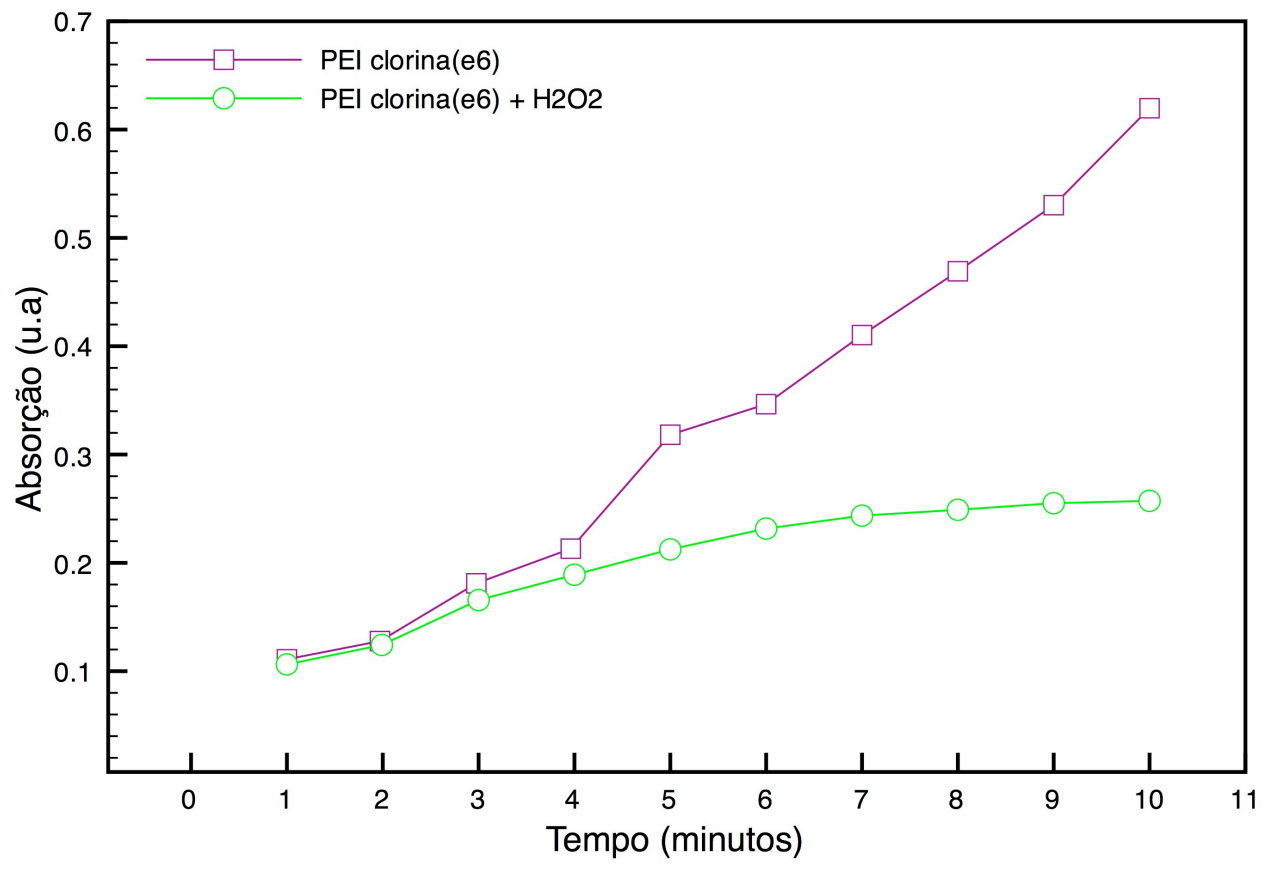

Gráfico 13: Formação de superóxido pela irradiação do conjugado a base de clorina e da associação deste fotossensibilizador ao $\mathrm{H}_{2} \mathrm{O}_{2}$.

\subsection{4 - Detecção indireta de ERO por oxidação do DCFH}

Os gráficos 14 e 15 mostram a dinâmica de formação de espécies reativas de oxigênio em solução aquosa e em solução de peróxido de hidrogênio. De forma sucinta, o composto DCFH na presença de ERO é convertido para DCF, um composto altamente fluorescente e facilmente detectável. Nota-se que a adição de peróxido diminui a intensidade de fluorescência para ambos os FS. 


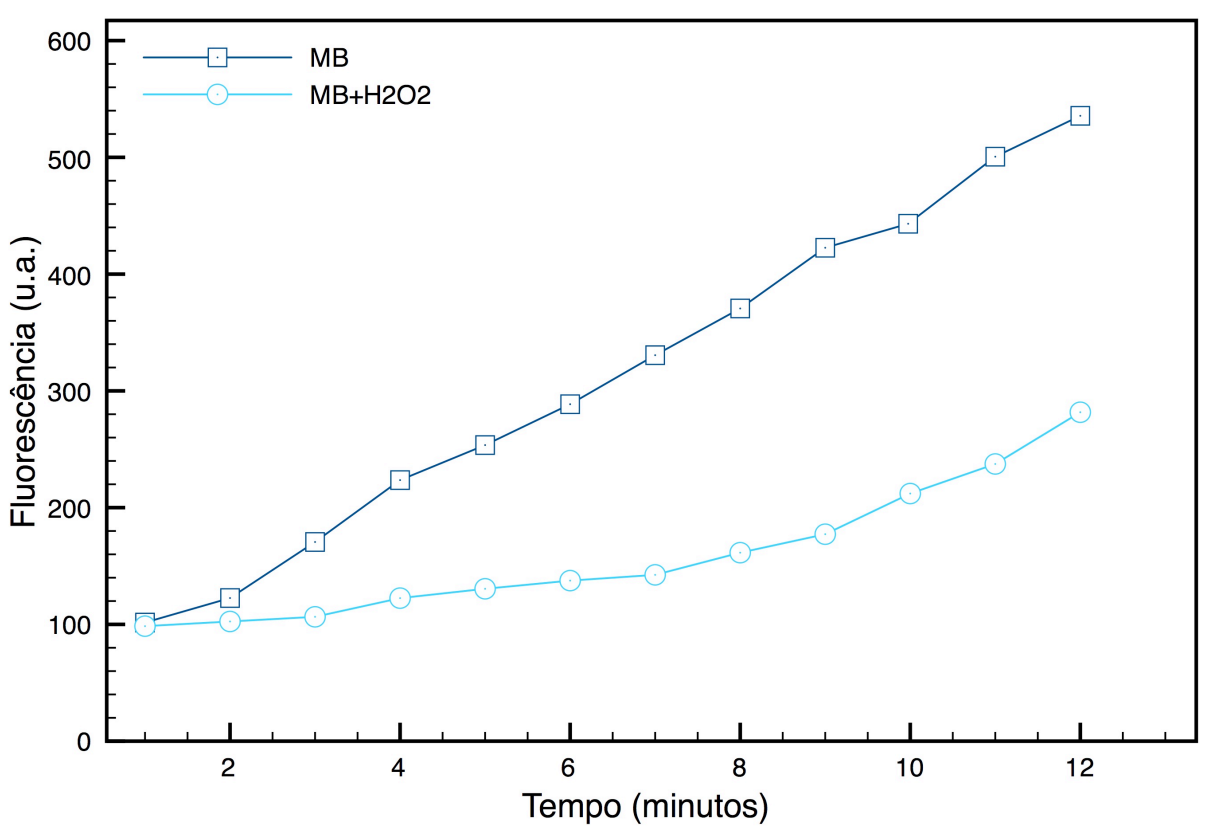

Gráfico 14: Formação de ERO pela irradiação do AM e deste fotossensibilizador associado ao $\mathrm{H}_{2} \mathrm{O}_{2}$.

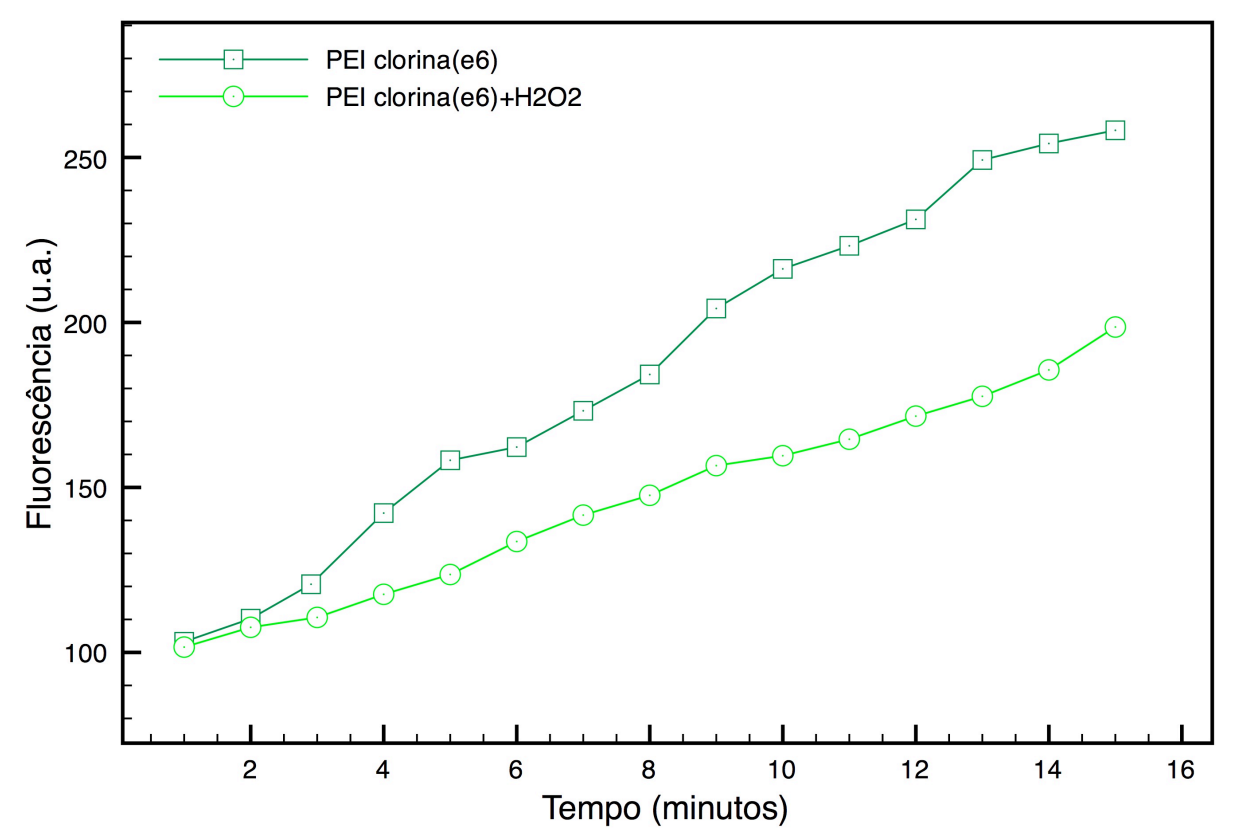

Gráfico 15: Formação de ERO pela irradiação do conjugado a base de clorina e deste fotossensibilizador associado ao $\mathrm{H}_{2} \mathrm{O}_{2}$. 
5.3.5 - Detecção indireta de ERO por oxidação do DCFH no interior de células eucarióticas

As figura 1 e 2 apresentam, respectivamente, a dinâmica de fluorescência do DCF no interior das células eucarióticas (C. albicans) em resposta a irradiação do azul de metileno em solução aquosa e na presença de $\mathrm{H}_{2} \mathrm{O}_{2}$, com o laser de diodo de emissão vermelha. O gráfico 16 mostra a formação de ERO em solução aquosa e em solução de peróxido de hidrogênio. 


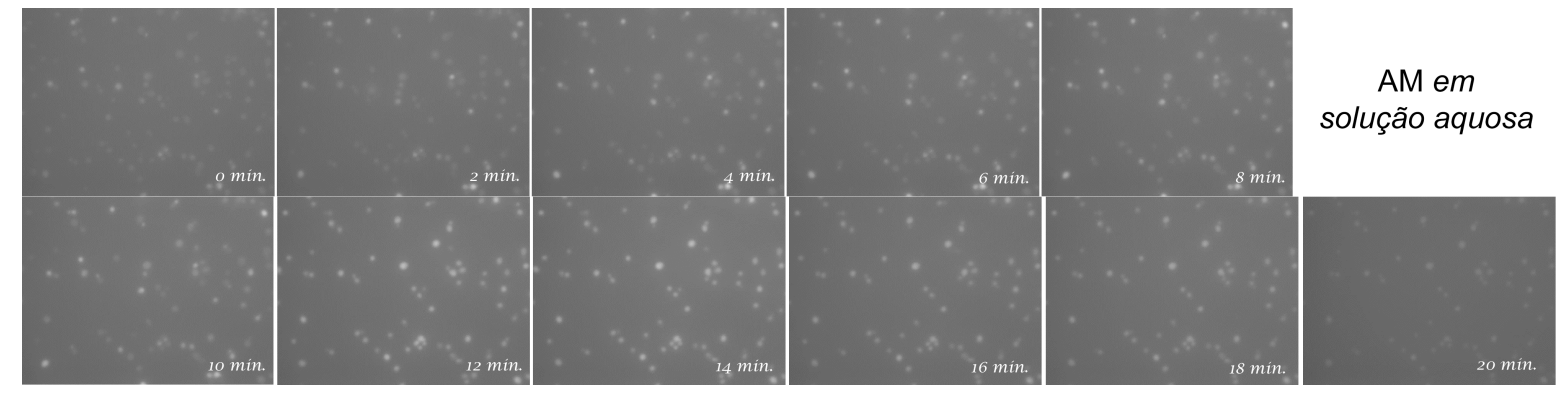

Figura 1: Suspensão de C. Albicans carregadas com DCFH na presença de AM. Microscopia de fluorescência das células após irradiação. Nota-se o aumento da intensidade de fluorescência do DCF pela foto-oxidação do DCFH na presença do FS em função do tempo de irradiação.

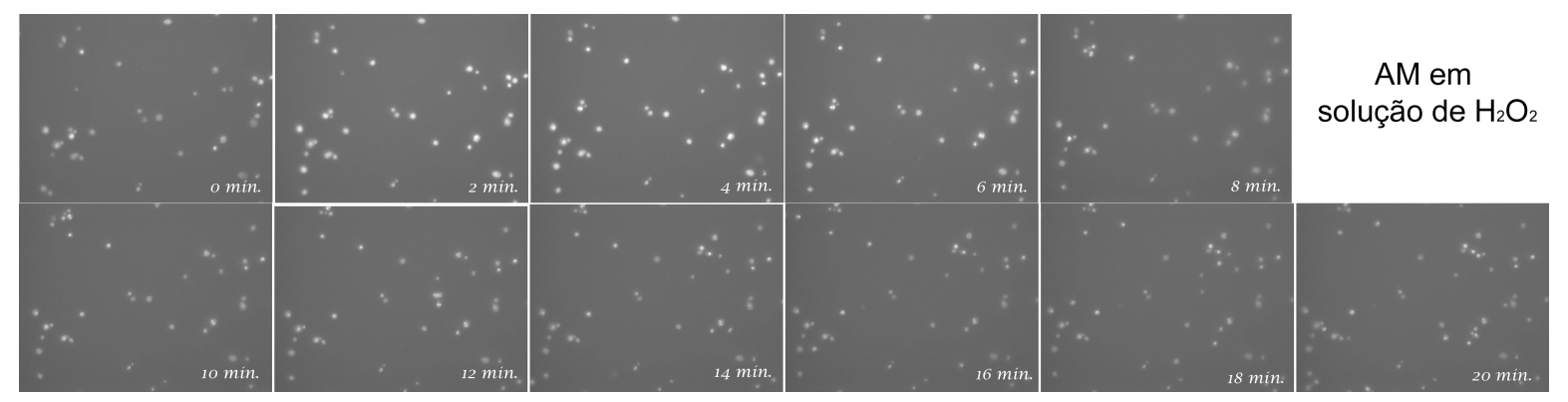

Figura 2: Suspensão de C. albicans carregadas com DCFH na presença de AM em solução de peróxido de hidrogênio. Microscopia de fluorescência das células após irradiação. Nota-se o aumento da intensidade de fluorescência nos minutos iniciais de irradiação quando comparado a dinâmica de fotooxidação do DCFH em presença do FS em solução aquosa. 


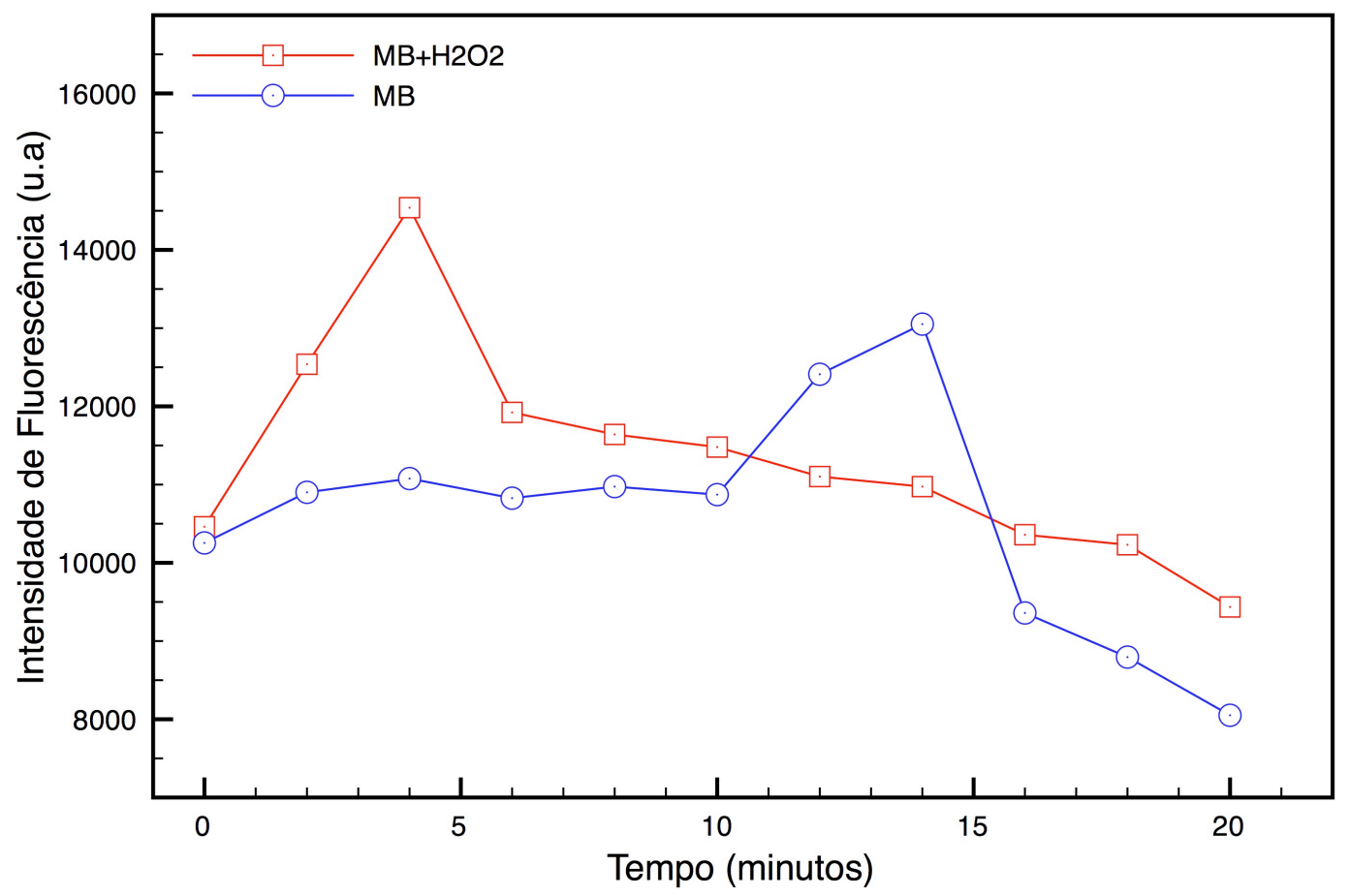

Gráfico 16: Formação de ERO pela irradiação do AM e deste

fotossensibilizador associado ao $\mathrm{H}_{2} \mathrm{O}_{2}$ no interior do fungo $C$. albicans.

Observa-se que quando o AM se encontra em solução aquosa, a dinâmica de formação de ERO ocorre mais lentamente, tendo-se o pico de formação com 14 min de irradiação. Na presença de $\mathrm{H}_{2} \mathrm{O}_{2}$, o pico de formação de ERO ocorre nos minutos iniciais de irradiação.

\section{4-ANÁLISE DOS MECANISMOS BIOFíSICOS E BIOQUÍMICOS ENVOLVIDOS NA PDT EM PRESENÇA DE PERÓXIDO DE HIDROGÊNIO}

\subsection{1-Captação do FS ou microrganismos sob ação de $\mathrm{H}_{2} \mathrm{O}_{2}$}

A análise da captação do AM pela E. coli após condicionamento prévio com peróxido de hidrogênio mostrou, que há uma maior captação de AM pela célula, observa-se no gráfico 17 que a concentração do AM diminui no sobrenadante após contato com $\mathrm{H}_{2} \mathrm{O}_{2}$. A menor concentração do $\mathrm{AM}$ no 
sobrenadante, independe do $\mathrm{H}_{2} \mathrm{O}_{2}$ ter sido usado como solvente ou ter condicionado previamente as células antes da incubação com o FS.

No Gráfico 18 nota-se, através da microscopia de fluorescência, que a concentração de clorina no interior da célula é maior quando o microrganismo é previamente condicionado com o peróxido ou quando o FS esta em solução com $\circ \mathrm{H}_{2} \mathrm{O}_{2}$, quando comparado ao $\mathrm{FS}$ em solução aquosa. Entretanto o condicionamento prévio com $\mathrm{H}_{2} \mathrm{O}_{2}$ aumenta a captação da clorina pelo fungo, mesmo quando comparado à captação da clorina quando a mesma está em solução de peróxido.

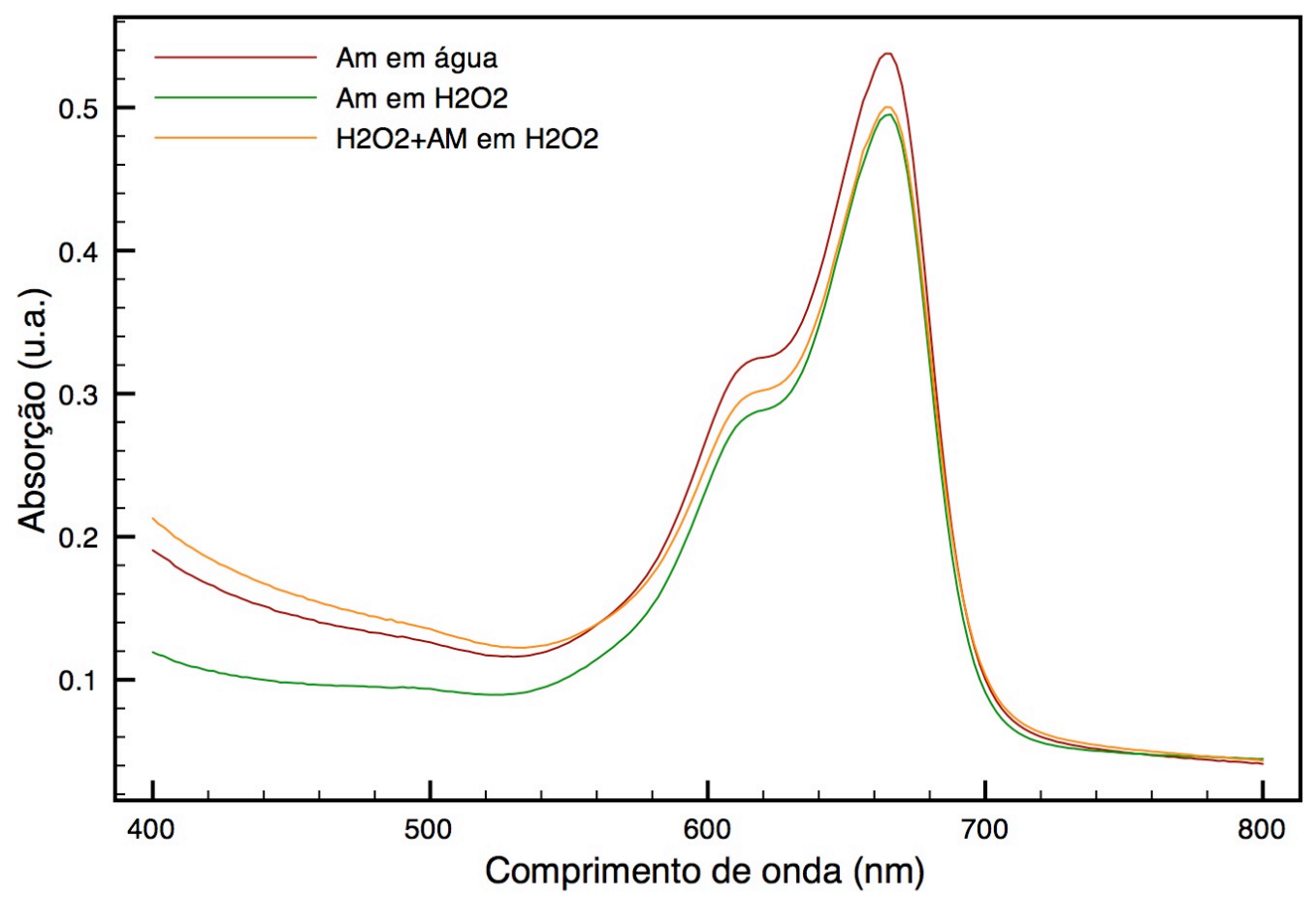

Gráfico 17: Espectroscopia de absorção do AM remanescente na solução após centrifugação e remoção das células. 


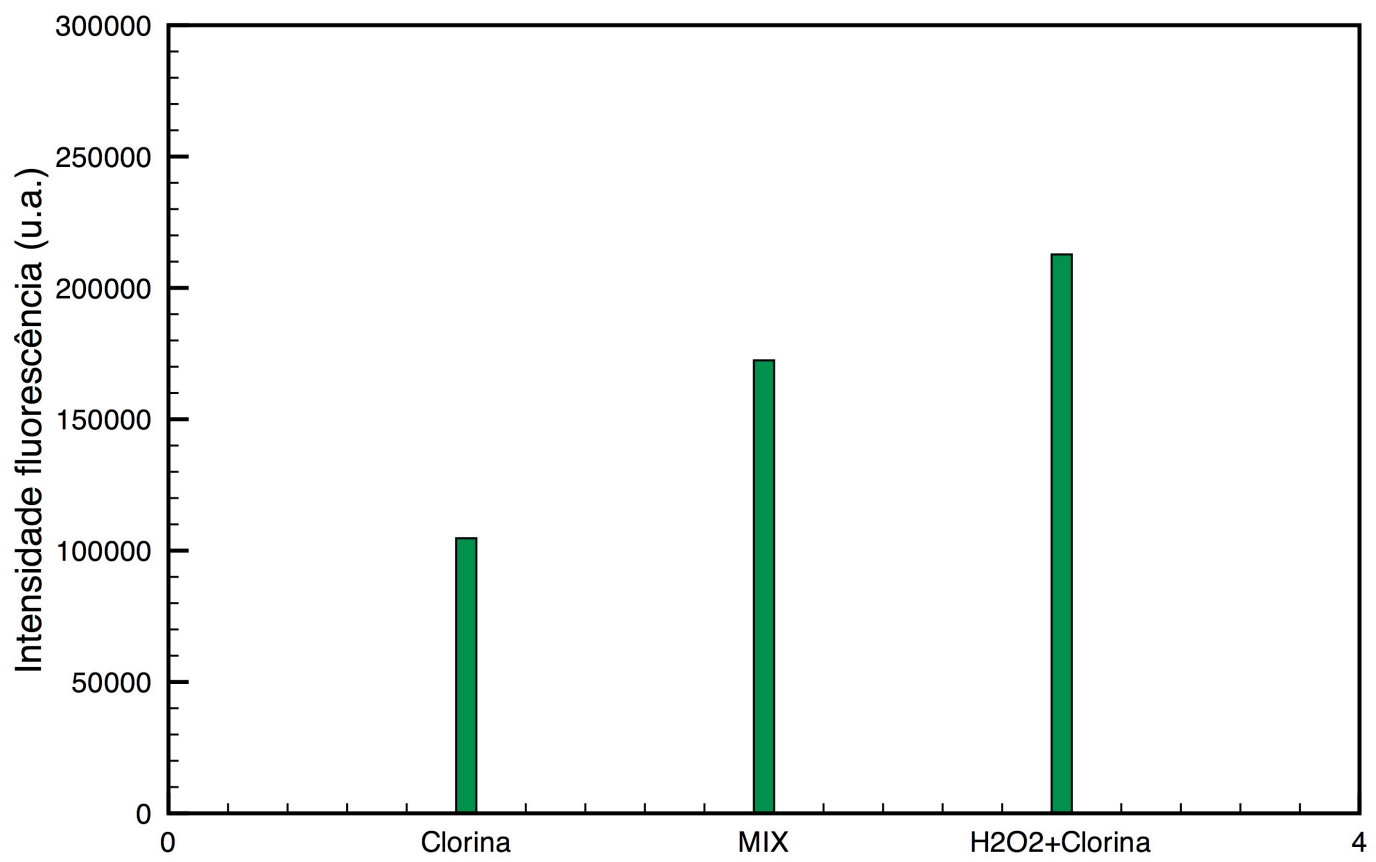

Gráfico 18: Intensidade de fluorescência do FS no interior das células quando excitado em $\lambda=490 \mathrm{~nm}$. Clorina $-\mathrm{FS}$ em solução aquosa, MIX - FS em solução de $\mathrm{H}_{2} \mathrm{O}_{2}$ a $3 \%$ e $\mathrm{H}_{2} \mathrm{O}_{2}+$ Clorina - condicionamento prévio do microrganismo com peróxido e posterior incubação com o FS.

\subsection{2 - MECANISMOS BIOQUÍMICOS DA MORTE BACTERIANA EM PRESENÇA DE PERÓXIDO}

Os gráficos 19 e 20 mostram a redução bacteriana nas diferentes seqüências de uso da associação dos fotossensibilizadores e a solução de peróxido de hidrogênio.

Não foram encontradas diferenças estatísticas significantes quando o microrganismo foi tratado previamente com $\mathrm{O} \mathrm{H}_{2} \mathrm{O}_{2}$, quando $\mathrm{O}$ fotossensibilizador foi diluído em $\mathrm{H}_{2} \mathrm{O}_{2}$, ou quando o microrganismo recebeu a PDT e subseqüentemente foi atacado com peróxido de hidrogênio. Porém, 
estes tratamentos foram mais efetivos do que a PDT utilizando o fotossensibilizador em solução aquosa.

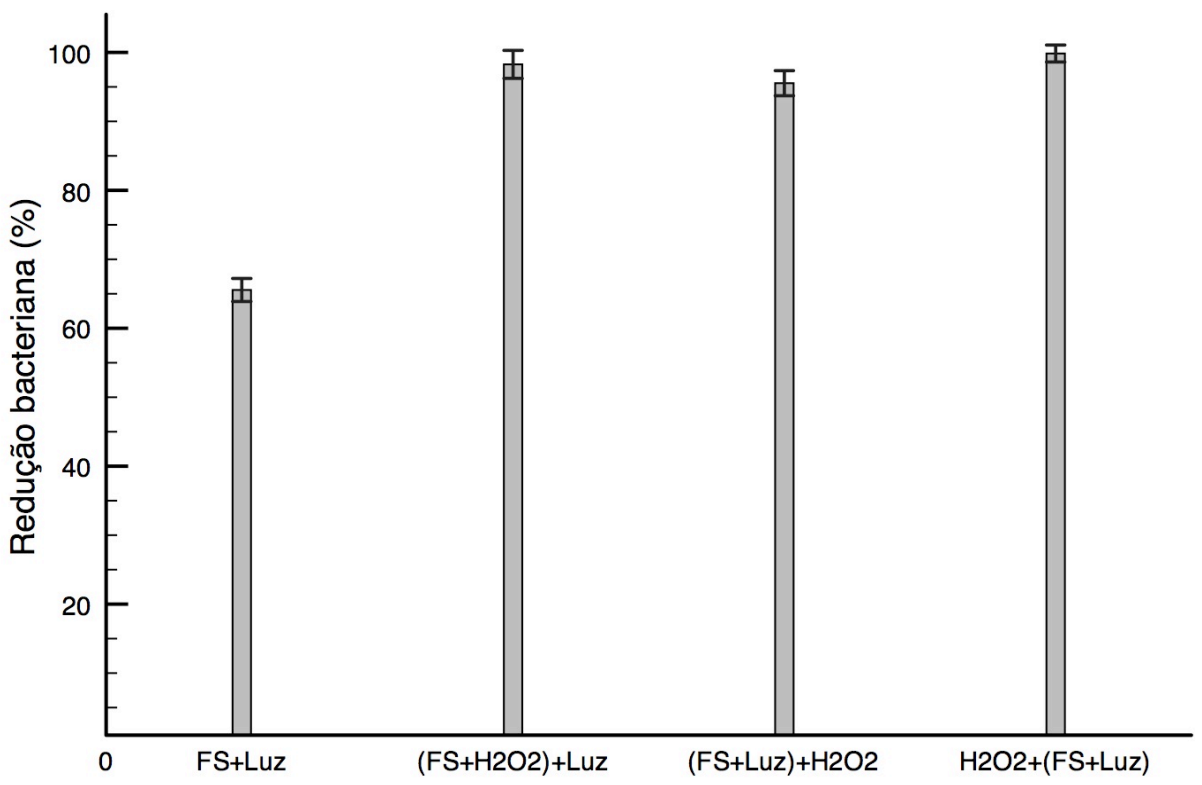

Gráfico 19: Médias e desvio padrão da redução microbiana após diferentes seqüências de tratamento utilizando AM como fotossensibilizador.

\begin{tabular}{|c|c|c|c|c|}
\hline & $\mathrm{AM}+$ & $\left(\mathrm{AM}+\mathrm{H}_{2} \mathrm{O}_{2}\right)+$ & $(\mathrm{AM}+\mathrm{Luz})+$ & $\mathrm{H}_{2} \mathrm{O}_{2}+(\mathrm{AM}+\mathrm{Luz})$ \\
& $\mathrm{Luz}$ & $\mathrm{H}_{2} \mathrm{O}_{2}$ & \\
\hline Redução bacteriana & 75,55 & 98,263 & 95,536 & 99,84 \\
\hline Desvio padrão & 1,67 & 2,03 & 1,82 & 1,23 \\
\hline
\end{tabular}

Tabela 10: Médias e desvio padrão da redução microbiana após diferentes seqüências de tratamento utilizando o AM como fotossensibilizador. 


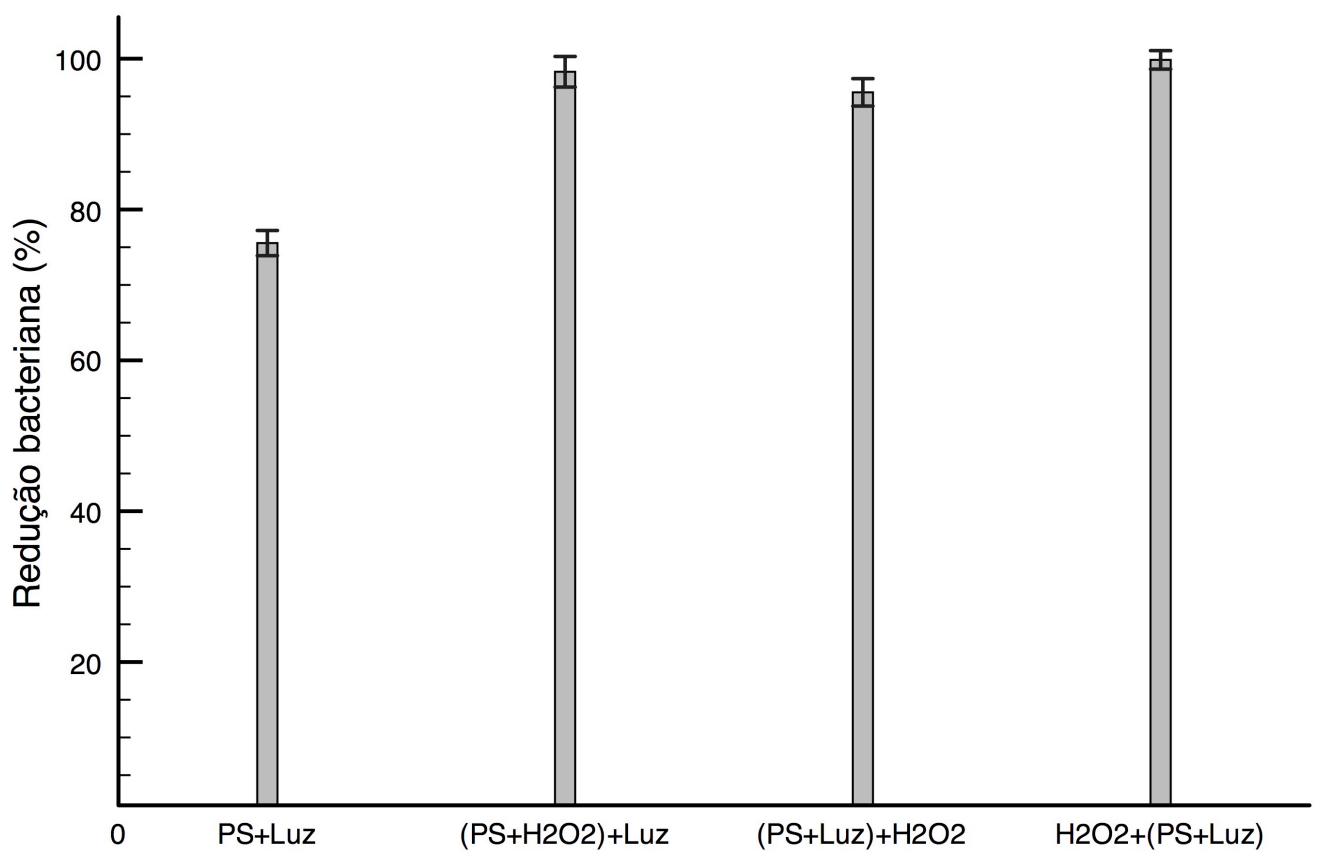

Gráfico 20: Médias e desvio padrão da redução microbiana após diferentes seqüências de tratamento, utilizando o conjugado a base de clorina como fotossensibilizador.

\begin{tabular}{|c|c|c|c|c|}
\hline & $\mathrm{FS}+\mathrm{Luz}$ & $\begin{array}{c}\left(\mathrm{FS}+\mathrm{H}_{2} \mathrm{O}_{2}\right)+\mathrm{L} \\
\mathrm{uz}\end{array}$ & $\begin{array}{c}(\mathrm{FS}+\mathrm{Luz})+ \\
\mathrm{H}_{2} \mathrm{O}_{2}\end{array}$ & $\mathrm{H}_{2} \mathrm{O}_{2}+(\mathrm{FS}+\mathrm{Luz})$ \\
\hline Redução bacteriana & 66,91 & 98,58 & 96,151 & 99,61 \\
\hline Desvio padrão & 2,98 & 1,01 & 2,65 & 2,4 \\
\hline
\end{tabular}

Tabela 11: Médias e desvio padrão da redução microbiana após diferentes seqüências de tratamento, utilizando o conjugado a base de clorina como fotossensibilizador. 


\section{6 - DISCUSSÃO}

Trabalhos prévios de nosso grupo utilizaram, tanto in vitro como in vivo, uma pasta à base de peróxido de uréia e um fotossensibilizador para redução microbiana contra microrganismos orais ${ }^{1,44,45,46}$. Nestes trabalhos o fotossensibilizador foi associado a uma pasta comumente empregada em odontologia com dois objetivos, primeiramente evitar a pigmentação do elemento dentário assim como dos tecidos adjacentes a este e também com o intuito de facilitar a reação fotodinâmica, aumentando a disponibilidade de oxigênio na área tratada e conseqüentemente a eficiência da terapia. Os resultados obtidos nesses trabalhos, assim como os trabalhos de MacCullagh e Robertson ${ }^{47,49}$ motivaram a continuação daqueles estudos, para verificar se a adição de peróxido de hidrogênio poderia melhorar a eficiência da terapia fotodinâmica, principalmente sobre microrganismos Gram- e elucidar os possíveis mecanismos envolvidos nesta associação.

Nos estudos supracitados ${ }^{44,45,46}$, foi verificado o aumento da eficiência fotodinâmica, em bactéria Gram+ e em flora microbiana oral de cães. Também pode ser constatada na literatura a eficiência da PDT sobre algas e cianobactérias, em presença de peróxido de hidrogênio. Para verificar a redução microbiana em diferentes microrganismos foram selecionadas neste estudo as bactérias: S. aureus uma bactéria Gram+, P. aeruginosa e E. coli bactérias Gram- e o fungo C. albicans.

Os resultados obtidos mostraram um aumento na morte microbiana quando da associação da PDT com $\circ \mathrm{H}_{2} \mathrm{O}_{2}$, confirmando os resultados anteriores e demonstrando que este efeito pode ser obtido sobre diferentes 
microrganismos, tanto Gram+ quanto Gram- e desde células procariontes até células eucariontes, in vitro ou in vivo em feridas contaminadas. A adição de $\mathrm{H}_{2} \mathrm{O}_{2}$ não interferiu de forma significativa na dinâmica de ação da PDT quanto à susceptibilidade dos microrganismos ao tratamento com ou sem a presença do peróxido de hidrogênio, apenas apresentando uma maior redução microbiana, e isso foi ressonante com os achados da literatura, isto é bactérias Gram+ continuaram a sofrer maior redução do que fungos e bactérias Gram- . A susceptibilidade do microrganismo à PDT é divido às características morfofisiológicas dos mesmos e essa característica não foi alterada pela ação do peróxido.

Estes dados também indicam que quanto maior a concentração utilizada de $\mathrm{H}_{2} \mathrm{O}_{2}$, maior foi a redução microbiana obtida. Este achado poderia indicar que é um efeito simples da somatória do efeito antimicrobiano das duas terapias, porém, a soma da toxicidade intrínseca do fotossensibilizador associado ao peróxido (em sua maior concentração) na ausência de irradiação, somado à morte microbiana resultante da PDT, os valores não atingem os obtidos pela PDT associada ao peróxido, mostrando não ser esta a dinâmica presente.

Para confirmar a hipótese de que o aumento da concentração de oxigênio disponível no meio, facilitaria a formação de espécies reativas de oxigênio, devido à maior probabilidade de transferência de energia ou transferência eletrônica entre o fotossensibilizador excitado e o substrato, foi avaliada a concentração de $\mathrm{O}_{2}$ disponível presente na água destilada e em uma solução de peróxido de hidrogênio a 1M. Os dados indicam que a solução de peróxido de hidrogênio apresenta, em temperatura ambiente, concentrações de 
$\mathrm{O}_{2}$, aproximadamente $25 \%$ superiores as da água destilada. Este aumento da presença de $\mathrm{O}_{2}$ dissolvido na solução de peróxido valida a hipótese proposta e explicaria os valores mais elevados de redução microbiana obtidos em nosso estudo, para todos os microrganismos avaliados.

Foote $^{12}$ afirma que em um ambiente rico em oxigênio há um predomínio da reação do tipo II, com formação de oxigênio singleto, devido a um processo de transferência de energia entre o fotossensibilizador excitado e o oxigênio tripleto. De Rosa ${ }^{61}$ complementa afirmando que este processo geralmente resulta na formação de $10^{3}$ a $10^{5}$ moléculas de oxigênio singleto.

O esperado para que confirmássemos a hipótese proposta era um aumento de até $25 \%$ na formação de oxigênio singleto, visto que em solução de peróxido foi este o valor encontrado da disponibilidade de $\mathrm{O}_{2}$, quando comparado à água destilada. Contudo, quando os mecanismos envolvidos nesta foto-reação foram avaliados in vitro, diferentemente do esperado, a produção de oxigênio singleto diminuiu quando o fotossensibilizador sofreu irradiação em presença de peróxido, comparado aos valores obtidos em solução aquosa. Os gráficos 9 e 10 mostram os valores relativos à formação de reação tipo II.

Os métodos espectrofotométricos de detecção utilizados neste estudo, foram métodos indiretos e os dados poderiam sofrer alterações visto que o composto RNO, não é oxidado diretamente pelas ERO. Sua oxidação se deve à captura do oxigênio singleto pela L-histidina, o que resulta na formação de uma substância intermediária capaz de induzir processos oxidativos neste composto e ainda, estas reações ocorrem em momentos distintos da deteç̧ão. De acordo com Kralik et al. ${ }^{41}$, na ausência de L-histidina, o RNO pode reagir 
com as ERO, mas esta reação é fraca e não significante. Para confirmar estes resultados foi realizado um experimento para a deteç̧ão direta do oxigênio singleto através de sua emissão fosforescente em $\lambda=1270 \mathrm{~nm}$. A detecção por ser direta e em tempo real, confirmou à diminuição da formação de oxigênio singleto, ratificando os dados obtidos anteriormente.

MacCullagh e Robertson ${ }^{47,49}$ trabalhando em uma atmosfera livre de oxigênio, substituído por argônio relataram a redução microbiana de algas a cianobactérias, sugerindo que a presença de oxigênio atmosférico não é necessária para que a reação fotodinâmica ocorra. Os autores concluem que na presença de peróxido de hidrogênio o AM apresenta formação de espécies reativas de oxigênio por reação do tipo I e também por reação do tipo II. Os mecanismos para a reação tipo I sugeridos nesse trabalho, indicam que o azul de metileno foto-excitado transfere um elétron para o $\mathrm{H}_{2} \mathrm{O}_{2}$ levando à formação de um radical hidroxila ou um radical hidroperoxila. Este possível mecanismo faz referência ao trabalho de Gak e colaboradores ${ }^{48}$. Esses autores investigaram a supressão do estado tripleto do fotossensibilizador foto-excitado pelo $\mathrm{H}_{2} \mathrm{O}_{2}$ e sugerem três possíveis caminhos para a reação: transferência de elétrons do FS excitado para o $\mathrm{H}_{2} \mathrm{O}_{2}$ com a formação de um radical cátion do FS e $\mathrm{OH}$, transferência de elétrons do $\mathrm{H}_{2} \mathrm{O}_{2}$ para a molécula do $\mathrm{FS}$ com a formação de um radical anion do $\mathrm{FS}$ e $\mathrm{HO}_{2}{ }^{*}$ ou supressão do estado tripleto excitado pelo $\mathrm{H}_{2} \mathrm{O}_{2}$ sem a formação de nenhum subproduto.

Nossos resultados indicam claramente que a reação tipo II é diminuída na presença de $\mathrm{H}_{2} \mathrm{O}_{2}$, restando, portanto, investigar a formação de ERO por reação tipo I para tentar justificar a hipótese inicial. 
Para isto foi avaliada a formação das ERO totais e radicais superóxido em suspensão e em suspensão na presença de microrganismos

LeBel $^{50}$ e Gomes ${ }^{54}$ indicam a utilização de compostos de fluoresceína para a detecção de espécies reativas de oxigênio, em especial os radicais hidroxila, LeBel recomenda a utilização do DCFH-DA como um interessante método, desde que utilizado com cuidado por ser este um método indireto, que depende de diversas reações intermediárias para seu correto funcionamento. Tegos $^{5}$, baseado no trabalho de Yamakoshi ${ }^{42}$, utiliza-se de um outro método também indireto para detecção de ERO mais seletivo para os radicais superóxidos. Bourré ${ }^{51}$, também utilizando o DCFH, indica este composto para a detecção de ERO em células.

Estes métodos empregados nesse estudo, com mecanismos distintos, avaliam de maneira específica dois radicais livres, mas como já citado anteriormente, por serem as espécies reativas de oxigênio moléculas de difícil detecção, eles avaliam como um todo as fotorreações do tipo I, mas com sensibilidade aumentada para as duas moléculas citadas, e detectam também, de maneira inespecífica, outras ERO.

Interpretando os resultados em conjunto podemos ter um panorama geral das reações fotoquímicas em presença de $\mathrm{H}_{2} \mathrm{O}_{2}$, e em específico dos radicais hidroxila e superóxido tanto intracelular como em reações em suspensão.

A formação de espécies reativas de oxigênio, como se pode notar pela análise dos gráficos 13,14, 15 e 16, também demonstrou uma diminuição na produção de ERO quando a reação fotodinâmica ocorreu na presença de peróxido de hidrogênio. Estes resultados estão em desacordo com a teoria de 
Gak e colaboradores ${ }^{48}$, que sugerem que 0 azul de metileno fotoexcitado transfere um elétron para o $\mathrm{H}_{2} \mathrm{O}_{2}$ levando à formação de um radical hidroxila.

Os dados obtidos em nossos experimentos invalidariam a hipótese de que uma maior disponibilidade de oxigênio no meio, proporcionada pelo uso de $\mathrm{H}_{2} \mathrm{O}_{2}$, resultaria em uma maior produção de ERO, pelo contrário, a adição de $\mathrm{H}_{2} \mathrm{O}_{2}$ estava inibindo a fotorreação, tanto para reações do tipo I como do tipo II.

Como já vimos em nossos resultados e fundamentados na literatura ${ }^{1,46,47,49}$, a adição de $\mathrm{H}_{2} \mathrm{O}_{2}$ aumenta a morte microbiana, portanto, outro mecanismo adicional aos mecanismos fotofísicos ou fotoquímicos deve estar ocorrendo para justificar um aumento na eficiência fotodinâmica.

Analisando por um aspecto fotobioquímico, a PDT com o fotossensibilizador aderido à membrana do microrganismo, mesmo com a diminuição de ERO formadas, poderia provocar rupturas na membrana, como visto por Caetano ${ }^{59}$ em vesículas gigantes unilamelares, que facilitaria o acesso do $\mathrm{H}_{2} \mathrm{O}_{2}$ ao interior da célula.

Para verificar esta hipótese, foi avaliada a produção de ERO no interior de C. albicans. A figura 1 mostra a dinâmica de formação de DCF resultante da oxidação do composto DCFH no interior do microrganismo após irradiação do azul de metileno como descrito por Bourré ${ }^{11}$. Baseado nas imagens de microscopia, obtidas na presença e na ausência de $\mathrm{H}_{2} \mathrm{O}_{2}$, a análise das intensidades de fluorescência em função do tempo de irradiação forneceu graficamente a cinética de formação do DCF. Os dados contidos no gráfico 17 mostram que na análise em suspensão na ausência de células, e utilizando-se de células eucariontes de $C$. albicans há, no interior das células, uma maior formação de ERO na presença de peróxido, principalmente nos momentos 
iniciais da irradiação do FS.

Como para a realização deste experimento, após incubação por 5 minutos, o DCFH não incorporado ao microrganismo for removido por centrifugação, podemos notar pelas figuras 1 e 2, que a formação das ERO ocorreu no interior da célula e/ou em contato íntimo com sua membrana celular, isto é, na proximidade de estruturas vitais para sobrevivência do microrganismo, possivelmente aumentando o dano oxidativo.

Nossos resultados conflitantes nos experimentos em solução poderiam ser explicados em função do $\mathrm{pH}$ do meio onde foram realizadas as reações, visto que a solução de peróxido de hidrogênio possui um $\mathrm{pH} 3$, e em pH ácido, o tempo de vida do estado tripleto é diminuído, por este ser um estado característico de meios básicos ${ }^{60,61,62}$. Este fato poderia influenciar a probabilidade do mesmo reagir com oxigênio ou diminuir a capacidade de detecção das espécies reativas. Entretanto, nos experimentos com o uso do DCFH-DA, tanto na reação em solução quanto na reação intracelular, o pH das soluções fotossensibilizadoras foi estabelecido em 4 , mostrando que em $\mathrm{pH}$ semelhante a dinâmica das reações se mantém inalterada.

Para tentar elucidar os mecanismos adicionais, responsáveis pelo aumento da morte microbiana, foram realizados experimentos onde foram alteradas as seqüências das etapas da PDT, para determinar se havia uma relação sinérgica entre a PDT e o $\mathrm{H}_{2} \mathrm{O}_{2}$, ou se estas terapias estariam agindo seqüencialmente.

Os gráficos 19 e 20 mostram que a alteração das etapas da PDT não apresentou diferenças estatísticas significantes entre elas, indicando apenas 
que o uso do $\mathrm{H}_{2} \mathrm{O}_{2}$ previamente à PDT conduz a um ligeiro aumento na redução bacteriana de $E$. coli.

Estudando o comportamento e a resistência bacteriana sob condições extremas e mudanças fisiológicas associadas a stress oxidativo, Baatout e colaboradores $^{63}$ mostraram que as cepas bacterianas testadas exibiram sensibilidade diferente ao $\mathrm{H}_{2} \mathrm{O}_{2}$ exógeno. Para todas as cepas estudadas pelos autores (Ralstonia metallidurans, E. coli, Shewanella oneidensis e Deinococcus radiodurans), algum dano pôde ser observado, como alteração na permeabilidade de membrana, no potencial de membrana, na atividade enzimática e alteração considerável do pH, quando concentrações mais altas de $\mathrm{H}_{2} \mathrm{O}_{2}$ foram utilizadas.

Baixas concentrações em doses únicas de peróxido de hidrogênio causam dramático aumento no acúmulo de substâncias com diferentes propriedades físico-químicas, para diferentes tipos celulares. Segundo Funk and $\mathrm{Krise}^{64}$, isso se deve possivelmente a uma alteração na difusão da membrana. Este condicionamento da célula com $\mathrm{H}_{2} \mathrm{O}_{2}$ facilitou o acúmulo das substâncias amarelo lucifer, verde de oregon e daunorubincina em diferentes tipos celulares (HL-60 e fibroblastos humanos).

Os resultados dos experimentos de captação do fotossensibilizador pela E. coli e C. albicans são consistentes com os achados de Funk and Krise ${ }^{64}$, mostrando maior captação dos FS tanto após condicionamento prévio com $\mathrm{H}_{2} \mathrm{O}_{2}$, como quando associado a este. Este maior acúmulo de fotossensibilizador no interior do microrganismo, próximo de importantes sítios de ação da PDT, como material genético e enzimas citoplasmáticas, pode explicar o aumento na morte do microrganismo. 
Uma segunda possibilidade deve ser considerada, a possível ação sinérgica das terapias. A PDT pode estar agindo sobre os microrganismos provocando morte em alguns, mas produzindo danos subletais em outros. $\mathrm{O}$ mesmo pode estar ocorrendo com $\circ \mathrm{H}_{2} \mathrm{O}_{2}$, entretanto, quando agindo sinergicamente, os danos subletais produzidos por cada uma das terapias em separado produzem danos letais, resultando assim em maior eficiência na redução microbiana.

Os resultados mostram que a dinâmica de ação da PDT associada ao $\mathrm{H}_{2} \mathrm{O}_{2}$ independe da natureza do FS, pelo menos para os FS utilizados neste estudo. Tanto em moléculas maiores como o conjugado a base de clorina quanto em uma molécula mais simples, como o azul de metileno, ocorre um aumento na redução microbiana e maior captação do FS pelo microrganismos após condicionamento com $\mathrm{H}_{2} \mathrm{O}_{2}$. 


\section{7- ESTUDOS FUTUROS ADICIONAIS}

Para melhor entender e confirmar os achados deste estudo deve ser realizada a detecção de espécies reativas de oxigênio no interior dos microrganismos, utilizando-se compostos que podem modificar a dinâmica da fotorreação, como supressores de radicais livres, antioxidantes ou substâncias potencializadoras da reação, como deutério, para verificar in situ a ação destes agentes sobre a reação fotodinâmica.

Estudos em células, principalmente em oncologia, podem se beneficiar do aumento da eficiência da terapia fotodinâmica exposta neste estudo.

O desenvolvimento de veículos mais apropriados para utilização clínica, principalmente em dermatologia e odontologia, deve ser estudado, viabilizando aplicações clínicas destes achados. 


\section{CONCLUSÃO}

\section{Conclusões específicas}

- A concentração de oxigênio molecular disponível em uma solução de peróxido de hidrogênio em ppm é maior do que a encontrada na água destilada;

- $\mathrm{O}$ uso de ambos os fotossensibilizadores em solução de $\mathrm{H}_{2} \mathrm{O}_{2}$ aumenta a redução microbiana para todos os microrganismos estudados. $O$ aumento na morte microbiana é maior, respectivamente, para bactérias Gram+, bactérias Gram- e fungos;

- Os mecanismos fotofísicos e fotoquímicos na presença de $\mathrm{H}_{2} \mathrm{O}_{2}$ apresentam uma diminuição na formação de ERO para ambos os FS;

- O condicionamento prévio com $\mathrm{H}_{2} \mathrm{O}_{2}$ ou o uso do $\mathrm{FS}$ em solução de peróxido leva a uma maior captação do FS pela célula;

- A PDT na presença de $\mathrm{H}_{2} \mathrm{O}_{2}$, o condicionamento prévio do microrganismo com $\mathrm{H}_{2} \mathrm{O}_{2}$ seguido da PDT ou a ação da PDT seguido do $\mathrm{H}_{2} \mathrm{O}_{2}$, não promove diferença significante na redução mirobiana, entretanto, estes valores são diferentes dos valores de redução microbiana obtida com o FS em solução aquosa. 


\section{Conclusões gerais}

De acordo com a metodologia utilizada e baseada nas análises dos dados obtidos, podemos concluir que:

A presença de peróxido de hidrogênio aumenta a eficiência da terapia fotodinâmica antimicrobiana nas bactérias Gram-positivas, Gram-negativas e fungos estudados.

Os dados obtidos neste estudo, indicam que os mecanismos envolvidos neste processo são conseqüência de uma reação sinérgica fotobioquímica relacionada à reação tipo I e aumento da permeabilidade de membrana celular. 


\section{REFERÊNCIAS BIBLIOGRÁFICAS}

1 Garcez AS, Nunez SC, Souza FR, Katter JM, Ribeiro MS. Terapia Fotodinâmica em Odontologia - Laser de Baixa Potência para Redução Microbiana. Rev Assoc Paul Cir Dent. 2003; 57:223 - 226

2 Demidova TN, Hamblin MR . Photodynamic inactivation of Bacillus spores mediated by phenothiazinium dyes. Appl Environ Microbiol. 2005; 71:6918-25

3 Hamblin MR, Hassan T. Photodynamic therapy: a new antimicrobial approach to infectious desease? Photochem photobiol Sci. 2004; 3:436-50

4 Wainwright M. Photodynamic antimicrobial chemotherapy (PACT) J Antimicrobial Chemotherapy. 1998; 42:13-28

5 Tegos GP, Anbe M, Yang C, Demidova TN, Satti M, Mroz P, Janjua S, Gad F, Hamblin MR. Protease-stable polycationic photosensitizer conjugates between polyethyleneimine and chlorin(e6) for broad-spectrum antimicrobial photoinactivation. Antimicrob Agents Chemother. 2006; 50; 1402-10

6 Wilson M, Burns T, Pratten J, Pearson GJ. Bacteria in supragingival plaque samples can be killed by low-power laser light in the presence of a photosensitizer. J Appl Bacteriol. 1995; 78: 569-74

7 Usacheva MN, Teichert MC, Biel MA. Comparison of the methylene blue and toluidine blue photobactericidal efficacy against gram-positive and gramnegative microorganisms. Lasers Surg Med. 2001; 29: 165-73

8 Usacheva MN, Teichert MC, Biel MA. The role of the methylene blue and toluidine blue monomers and dimers in the photoinactivation of bacteria. $\mathrm{J}$ Photochem Photobiol B. 2003; 71: 87-98 
9 Tegos GP, Hamblin MR. Phenothiazinium antimicrobial photosensitizers are substrates of bacterial multidrug resistance pumps. Antimicrob Agents Chemother. 2006; 50: 196-203

10 Phoenix DA, Sayed Z, Hussain S, Harris F. Wainwright M. The phototoxicity of phenothiazinium derivates against Escherichia coli and Staphylococcus aureus. FEMS Immun Med Microbiol. 2003; 39: 17-22

11 Bhatti M, MacRobert A, Meghii S, Henderson B, Wilson M. A study of the uptake of toluidine blue $\mathrm{O}$ by Porphyromonas gingivalis and the mechanism of lethal photosensitization. Photochem Photobiol. 1998; 68: 370-6

12 Foote CS. Definition of type I and Type II photosensitized oxidation. Phochem Photobiol. 1991; 54: 659

13 Mohr H, Bachmann B, Klein-Struckmeier A, Lambrecht B. Virus inactivation of blood products by phenothiazine dyes and light. Photochem Photobiol. 1997; 65: $441-5$

14 Melly E, Cowan AE, Setlow P. Studies on the mechanism of killing of Bacillus subtilis spores by hydrogen peroxide. J Appl Microbiol. 2002; 93: 316-25 15 de Haas ER, Kruijt B, Sterenborg HJ, Martino Neumann HA, Robinson DJ. Fractionated illumination significantly improves the response of superficial basal cell carcinoma to aminolevulinic acid photodynamic therapy. J Invest Dermatol. 2006; 126: 2679-86.

16 Nunez SC. Estudo da dinâmica de fotodegradação e agregação das fenotiazinas Azul de Metileno e Azul de Orto -Toluidina com realçao à eficiência fotodinâmica. Tese doutorado IPEN/CNEN SP 2007

17 Ackroyd R, kelty C, Brown N, Reed M. The history of photodetection and photodynamic theraphy. Photochem Photobiol. 2001; 74: 656-669 
18 Yoshikawa TT. Antimicrobial resistance and aging: beginning of the end of the antibiotic era? J Am Geriatr Soc. 2002; 50: 226-9

19 Livermore DM. Antibiotic resistance in staphylococci. Int J Antimicrob Agents. 200116: 3-10

20 Wise R, Hart T, Cars O. Antimicrobial resistance. Br Med J. 1998 37: 609-10 21Dobson J, Wilson M. Sensitization of oral bacteria in biofilms to killing by light from a low-power laser. Arch Oral Biol. 1992; 37: 883-7

22 Wilson M, Dobson J, Harvey W. Sensitization of oral bacteria to killing by low-power laser radiation. Curr Microbiol. 1992; 25: 77-81

23 Wilson M, Dobson J, Sarkar S. Sensitization of periodontopathogenic bacteria to killing by light from a low-power laser. Oral Microbiol Immunol. 1993; 8: $182-7$

24 Soukos NS, Wilson M, Burns T, Speight PM. Photodynamic effects of toluidine blue on human oral keratinocytes and fibroblasts and Streptococcus sanguis evaluated in vitro. Lasers Surg Med. 1996; 18: 253-9

25 Sailer R., Strauss W.S.L., König K., Rück A., Steiner R. Correlation between porphyrin biosyntesis and photodynamic inactivation of Pseudomonas aeruginosa after incubation with 5-aminolaevulinic acid. J Photchem Photobiol B. 1997 ; 39: 236-42

26 Walsh LJ. The current status of low level laser therapy in dentistry. Part 2. Hard tissue applications. Aust Dent J. 1997; 42: 302-6

27 Soukos NS, Ximenez-Fyvie LA, Hamblin MR, Socransky SS, Hasan T. Targeted antimicrobial photochemotherapy. Antimicrob Agents Chemother. 1998; 42: 2595-601 
28 Jackson Z, Meghii S, MacRobert A, Henderson B, Wilson M. Killing of the yeast and hyphal forms of Candida albicans using a light-activated antimicrobial agent. Lasers Med Sci. 1999; 14: 150-7

29 Kawamoto K, Senda N, Shimada K, Ito K, Hirano Y, Murai S. Antibacterial effect of yellow He-Ne laser irradiation with crystal violet solution on Porphiromonas gingivalis: na evaluation using experimental rat model involving sobcutaneous abscess. Lasers Med Sci. 2000; 15: 257-62

30 Silbert T, Bird PS, Milburn GJ, Walsh LJ. Disinfection of root canals by laser dye photosensitization. J Dent Res. 2000; (IADR abstrats) 79: 569

31 Maisch T. Anti-microbial photodynamic therapy: useful in the future? Lasers Med Sci. 2007; 22: 83-91

32 Garcez AS, Ribeiro MS, Tegos GP, Nunez SC, Jorge AO, Hamblin MR. Antimicrobial photodynamic therapy combined with conventional endodontic treatment to eliminate root canal biofilm infection. Lasers Surg Med. 2007; 39: $59-66$

33 Ovchinnikov IS, Tuchin VV. Photodynamic action on some pathogenic microorganisms of oral cavity. ECBO 2001

34 Usacheva MN, Teichert MC, Biel MA. Comparison of the methylene blue and toluidine blue photobactericidal efficacy against gram-positive and gramnegative microorganisms. Lasers Surg Med. 2001; 29: 165-73

35 Hamblin MR, O'Donnell DA, Murthy N, Rajagopalan K, Michaud N, Sherwood ME, Hasan T. Polycationic photosensitizer conjugates: effects of chain length and Gram classification on the photodynamic inactivation of bacteria. J Antimicrob Chemother. 2002; 49: 941-51 
36 Teichert MC, Jones JW, Usacheva MN, Biel MA. Treatment of oral candidiasis with methylene blue-mediated photodynamic therapy in an immunodeficient murine model. Oral Surg Oral Med Oral Pathol Oral Radiol Endod. 2002; 93: 155-60

37 Usacheva MN, Teichert MC, Biel MA. The role of the methylene blue and toluidine blue monomers and dimers in the photoinactivation of bacteria. $\mathrm{J}$ Photochem Photobiol B. 2003; 71: 87-98

38 O'Riordan K, Akilov OE, Hasan T. The potential for photodynamic therapy in the treatment of localized infections. Photodiag Photodynamic Ther. 2005; 2: 247-62

39 Jori G. Photodynamic therapy of microbial infections: state of the art and perspectives. J Environ Pathol Toxicol Oncol. 2006; 25: 505-19

40 Tegos GP, Anbe M, Yang C, Demidova TN, Satti M, Mroz P, Janjua S, Gad F, Hamblin MR. Protease-stable polycationic photosensitizer conjugates between polyethyleneimine and chlorin(e6) for broad-spectrum antimicrobial photoinactivation. Antimicrob Agents Chemother. 2006; 50:1402-10

41 Kralic I and Mohsni SE. A new method for the detection of singlet oxygen in aqueous solution. Photochem. Photobiol. 1978; 28: 577-581

42 Yamakoshi Y, Umezawa A, Ryu K, Arakane N, Miyata Y, Goda T, Masumizu T, Nagano T. Active oxygen species generated from photoexcited fullerene (C60) as potential medicines: O2* versus 102. J Am Chem Soc. 2003; 125: $12803-12809$

43 Jori G, Fabris C, Soncin M, Ferro S, Coppellotti O, Dei D, Fantetti L, Chiti G, Roncucci G. Photodynamic therapy in the treatment of microbial infections: 
basic principles and perspective applications. Lasers Surg Med. 2006; 38: 46881

44 Garcez AS, Nunez SC, Zezzel DM, Ribeiro MS. Um novo agente fotossensibilizador para terapia fotodinâmica antimicrobiana. In: PDT 2002, São Pedro. Resumos - Terapia Fotodinâmica: Complexos de Moléculas Fotoativas e suas Aplicações, 2002; 175-6

45 Hayek RR, Araujo NS, Gioso MA, Ferreira J, Baptista-Sobrinho CA, Yamada AM, Ribeiro MS. Comparative study between the effects of photodynamic therapy and conventional therapy on microbial reduction in ligature-induced peri-implantitis in dogs. J Periodontol. 2005; 76: 1275-81

46 Silva Garcez A, Núñez SC, Lage-Marques JL, Jorge AO, Ribeiro MS. Efficiency of $\mathrm{NaOCl}$ and laser-assisted photosensitization on the reduction of Enterococcus faecalis in vitro. Oral Surg Oral Med Oral Pathol Oral Radiol Endod. 2006; 102: e93-8

47 McCullagh C, Robertson PK. Photo-dynamic biocidal action of methylene blue and hydrogen peroxide on the cyanobacterium Synechococcus leopoliensis under visible light irradiation.J Photochem Photobiol B. 2006; 83: 63-8

48 Gak VY, Nadtochenko VA, Kiwi J. Triplet-excitated dyes molecules (eosine and methilene blue) quenching by $\mathrm{H} 2 \mathrm{O} 2$ in aqueous solution. J Photochem Photobiol A. 1998; 116: 57-62

49 McCullagh C, Robertson PK. Photosensitized destruction of Chlorella vulgaris by Methylene Blue or Nuclear Fast Red combined with hydrogen peroxide under visible light irradiation. Environ Sci Technol. 2006; 40: 2421-5 
50 LeBel CP, Ischiropoulos $\mathrm{H}$, Bondy SC. Evaluation of the probe $2^{\prime}, 7^{\prime}-$ dichlorofluorescin as an indicator of reactive oxygen species formation and oxidative stress. Chem Res Toxicol. 1992; 5: 227-31

51 Bourre L, Thibaut S, Briffaud A, Rousset N, Eleouet S, Lajat $\mathrm{Y}$, Patrice T. Indirect detection of photosensitizer ex vivo. J Photochem Photobiol B. 2002; 67: 23-31

52 Keston AS, Brandt R. The fluorometric analysis of ultramicro quantities of hydrogen peroxide, Anal. Biochem. 1965; 11: 1-5

53 Wan XS, Zhou Z, Kennedy AR. Adaptation of the dichlorofluorescein assay for detection of radiation-induced oxidative stress in cultured cells. Radiat Res. 2003; 160: 622-30

54 Gomes A, Fernandez E, Lima JLFC. Fluorescence probes used for detection of reative oxygen species. J Biochem Biophys Methods. 2005; 65: 45-80

55 Bartosz G. Use of spectroscopic probes for detection of reactive oxygen species. Clin Chim Acta. 2006; 3681: 53-76.

56 Maisch T, Baier J, Franz B, Maier M, Landthaler M, Szeimies RM, Baumler W. The role of singlet oxygen and oxygen concentration in photodynamic inactivation of bacteria. Proc Natl Acad Sci USA. 2007; 104: 7223-8

57 Korystov YN, Shaposhnikova VV, Korystova AF, Emel'yanov MO. Detection of reactive oxygen species induced by radiation in cells using the dichlorofluorescein assay. Radiat Res. 2007; 168: 226-32

58 Jett BD, Hatter KL, Huycke MM, Gilmore MS. Simplified agar plate method for quantifying viable bacteria. Biotechniques. 1997; 23: 648-650 
59 Caetano W, Haddad PS, Itri R, Severino D, Vieira VC, Baptista MS, Schroder AP, Marques CM. Photo-induced destruction of giant vesicles in methylene blue solutions. Langmuir. 2007; 23: 1307-14

60 Skovsen E, Snyder JW, Lambert JDC, Ogilby PR. Lifetime and Diffusion of Singlet Oxygen in a cell. J Phis Chem B. 2005; 109: 8570-3

61 Deroa MC, Crutchley RJ. Photosensitised singlet oxygen and its applications. Coord Chem Ver. 2002; 133-134: 351-71

62 Gorman AA, Rodgers MAJ. Current perspective of singlet oxygen detection in biological enviroments. J Photochem Photobiol B Biol. 1992; 14: 159-76

63 Baatout S, De Boever P, Mergeay M. Physiological changes induced in four bacterial strains following oxidative stress. Prikl Biokhim Mikrobiol. 2006; 42: 418-27

64 Funk RS and Krise JP. Exposure to Hydrogen peroxide can increase the intracellular accumulation of drugs. Mol Pharm. 2007; 4: 154-9 